IY YIVERSIDADE DE SÁO PAULO

INSTITUTO DE QuímICA

CARACTERIZACÃO DE DISINTEGRINAS DE VENENOS VIPERÍDEOS COMO FERRAMENTAS SELETIVAS NA DETECCÃO OL INIBICÃO DA FUNĊ̃O DE INTEGRINAS

DIEGO ALBERTO BUTERA WADSW'ORTH TESE DE DOLTORADO

ORIENTADORA: DRA. ANA MARIA MOURA DA SLVA

$$
\text { SÀo PAULo }
$$

30 de Outubro de 2003 
"Caracterização de disintegrinas de venenos viperídeos como ferramentas seletivas na detecção ou inibição da função de integrinas"

\section{DIEGO ALBERTO BUTERA WADSWORTH}

Tese de Doutorado submetida ao Instituto de Química da Universidade de São Paulo como parte dos requisitos necessários à obtenção do grau de Doutor em Ciências - Área: Bioquímica.

\section{Aprovada(o) por:}

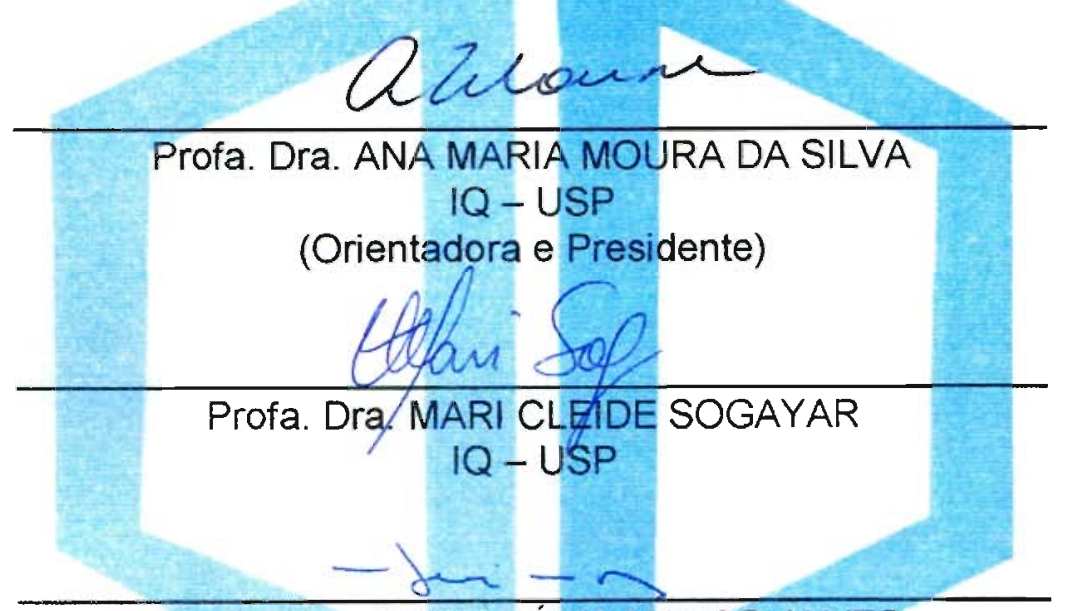

Profa. Dra. MARIA JÚLIA MANSO ALVES

IQ - USP

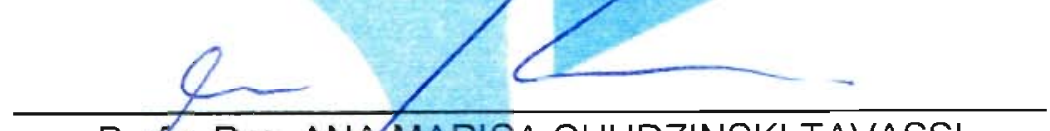

Profa. Dra. ANA MARISA CHUDZINSKI TAVASSI

IB

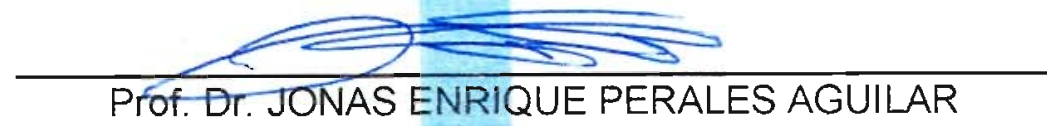

FIOCRUZ - RJ

SÃO PAULO

15 DE DEZEMBRO 2003. 
...A minha mãe, por existir

....A meu pai, pelo apoio e exemplo 


\section{Zona Franca}

\section{EL ARBOL}

Yo te doy el aire que respiras.

Te doy la sombra que deseas cuando te queman los rayos del sol.

Tu me dejas la mierda que tiras.

Te vas, y quedan esparcidas todas tus sabras a mi alrededor.

No puedo ni moverme

y me revienta la impotencia

solo me queda resignarme y quedar pasivo ante tu violencia. Yo te doy el paisaje que admiras cuando llevas a tu familia días felices de excursión.

Tu con fuego me quemas, vida apagada

y con tu tala descontrolaras.

Me dejas al borde de la extinción

Disidencia

"O paper é o alvo da pesquisa do doutor, e não consequuência dum objetivo maior..."

Dick Watson

Os sonhos não devem ser consumados

Dick Watson

¿Y si en vez de planear tanto voláramos un poco más alto?

Mafalda
"O dia que controlemos o momento de nossa morte nos apropriaremos de nossa existência".

$$
\text { Jose Silva }
$$

\footnotetext{
"As emoções aparecem na espécie humana como um artificio da
} natureza para compensar o raciocinio. Um homem exclusivamente racional se apropriaria de seu destino correndo perigo sua existência".

Jose Silva

A evolução individual é limitada...

Oscar White

$$
\begin{gathered}
\text { "Quem não desconfia de } \\
\text { sim mesmo não merece a } \\
\text { confiança dos outros" } \\
\text { Malba Tahan }
\end{gathered}
$$

\section{Viver Mata!}

Titulo de filme
Los genios son para una sociedad aquellos individuos que al ser comparados con ésta, resultan ser superiores, nunca aquellos que no pueden ser comparados.

Santo Cachón

"Como siempre: lo urgente no deja tiempo para lo Importante." 


\section{AGRADECIMENTOS}

A Ana (orientadora) pela oportunidade, confiança, incentivo, preocupação, carinho e exemplo.

A minha mãe por ter enchido tanto para que estudasse.

A meu pai por todo o apoio e por torcer sempre tanto por mim.

A mis abuelos pelo primeiro contato com a natureza.

A Andreita pelo amor, carinho, exemplo, respeito, paciência, etc, etc.

Ao Bicho pela amizade, companheirismo e generosidade.

A Mel, minha bebe, por ter me feito sentir tanto durante duas semanas.

A minhas irmãs por ter me apoiado sempre com minhas loucuras.

A Mono Blanco e Target, por dar-me tantas alegrias.

A Marú e Karlita pela amizade, carinho e por tanta coisa que passamos juntos.

Ao Pelicano e a Maria de Fátima Furtado por ter-me induzido a vir pro Brasil.

A Maisa, pelo comparherismo, amizade, carinho, paciência, caronas, e prêrnios.

A Bellinha, pela amizade, entusiasmo e papers.

A Geralda, pelas piadas, discussões e por meia cama.

A Luciana, pelos testes de adesão e pela amizade.

A Telma e Cris pelos copinhos

A Karen, ao André pela ajuda com os clones.

A Fernandinha pela ajuda com as referências.

A Claine pela amizade e também pelo teste de agregação

Ao Álvaro pelo Stryer, por ajudar-me para a prova de bioquímica e por tanta ajuda prática.

Ao Celso pelas inumeráveis discussões, dicas e ajuda prática.

A Inácio pela correção desta tese, pelas bactérias competentes, french press, discussões, viagens, etc.

A Ingrid também pelas bactérias competentes.

A Ivana pela amizade, conselhos e discussões.

A Moniquim pela amizade e exemplo.

A Diva Cardoso pelas recordações.

Ao Paulinho pelos conselhos e amizade

Ao Patrick e ao Johny, pelas discussões, amizade, etc.

A Cleusa, pela amizade e sempre boa disposição.

A Teresa, pelo profissionalismo e amizade.

A Iranilde, Jô, Jussara, Gerson, Chiquinho 
A Patricia, Vivian, Letícia, Denise, Tânia, Danielle, Alice, Ana Amelia, Lidiane, Guilherme, Andrèia, Edna, Claudia, Marilia, Ana Flavia, Diana, Denise e Amanda.

A Mônica Colombini e a Patrícia Bianca pela ordem e disciplina

Ao Miguel e ao Fernando pelas inumeráveis conversas, carinho e compreensão

Ao Enrique pelo exemplo de pessoa, amizade.

A Mary Ann McLane da Universidade de Delaware, por ceder-me seu laboratório durante um mês e pelas inumeráveis discussões.

A Frederic Ducancel pelos vetores pLIP, as discussões, exemplo e amizade

A Dulce pelo modelo.

A Irene pela correção desta tese e pela amizade.

A Kátia, Fernandona, Harumi e ao Dr. Ivan Mota.

A Solange pela ajuda e amizade vontade.

A Cibele e a Mitton da Secretaria do IQ/USP pela disposição e sempre boa

A Cristina, ao Terenzi e a Suely da Pro-reitoria da Pós-graduação pela ajuda brindada durante todos estes anos.

A Lourdes de Cooperaçâo Internacional da USP pela ajuda, disponibilidade e paciência ano trảs ano.

Ao Nivaldo, pela disponibilidade, bom humor e as fotocópias.

Às enfermeiras do Hospital Vital Brazil pelas inumeráveis colhidas de sangue.

Dulce, Diva e Gilda de RH pela ajuda.

As tiazinhas da biblioteca do Butantan.

Aos Professores que de alguma maneira influenciaram meus rumos: Fred Garcia, Ivan Ramirez, Roger Chammas, André Menez e Frederic Ducancel.

Ao Instituto Butantan, USP, FAPESP e CNPq.

Ao Brasil por fazer-me sentir brasileiro

Finalmente queria agtadecer a cada individuo que formou parte do meio ambiente que induziu a expressão de emoções e pensamentos em mim, tornando-me um ser melhor.

Obrigado! 


\section{ÍNDICE}

$\begin{array}{ll}\text { RESUMO } & 001\end{array}$

$\begin{array}{ll}\text { ABSTRACT } & 002\end{array}$

$\begin{array}{ll}\text { ABREVIAÇÕES } & 003\end{array}$

$\begin{array}{ll}\text { INTRODUÇÃO } & 004\end{array}$

$\begin{array}{ll}\text { I. INTEGRINAS } & 004\end{array}$

1 Caracteristicas estruturais e funcionais 004

2. Integrinas e plaquetas 006

3. Integrinas e câncer 008

3. 1. Transformaçăo maligna 008

3.2. Tumor primário 010

3.3. Metástase 011

3.4. Angiogênese 013

4. Diagnósticos envolvendo integrinas 014

$\begin{array}{ll}\text { II. DISINTEGRINAS } & 014\end{array}$

1. As metaloproteinases de veneno 014

1. 1. Estrutura e função das SVMP 017

$\begin{array}{ll}\text { OBJETIVOS } & 025\end{array}$

MATERIAIS E MÉTODOS

I. MATERIAL 026

1. Reagentes 026

2. Kits 026

3. Anticorpos 027

4. Soluções 027

5. Vetores 029

6. Cepas Bacterianas 032

7. Linhagens Celulares 032

8. Programas 033

I. MÉTODOS 034

1. Amplificação dos fragmentos de DNA por PCR 034

2. Purificação dos fragmentos de DNA 034

3. Eletroforese em gel de agarose 035

4. Extração de um fragmento de DNA a partir de um gel de agarose 035

5. Digestões com as endonucleases de restrição 036

6. Reações de ligação 037

7. Preparação de bactérias competentes 037

8. Transformação 037

9 Preparação do DNA do plasmideo 038

10. Determinação da concentração de DNA 039

11. Triagem das colônias $\quad 039$ 
12. Seqüenciamento 040

13. Mutagênese Sítio-dirigida $\quad 040$

14. Expressão 040

15. Extração celular 041

16. Lise bacteriana 041

17. Extração periplásmica 042

18. Dosagem de proteinas 042

19. Eletroforese em gel de poliacrilamida contendo SDS (SDS-PAGE) 043

20. Western Blotting 043

21. Ligação ao colágeno por teste imunoenzimático 044

22. Isolamento das proteínas em fusăo com GST 044

23. Purificação em sistema de HPLC 045

24. Obtenção de plaquetas 045

25. Teste de inibição da agregação plaçuetária 046

26. Cultura celular 046

27. Atividade fosfatase alcalina $\quad 046$

28. Teste de dot blot 047

RESULTADOS 048

I. CARACTERUZAÇ̃̃O DA REGLÃO FUNCIONAL DOS DOMUINOS ECD-

DISINTEGRINA E RICO-EM-CISTEINNAS (JARARAGNA-C) 048

1. Planejamento 048

2. Clonagem 052

3. Expressão 056

4. Purificação dos fragmentos 057

5. Atividade biológica 058

6. Caracterização do fragmento JD49 063

II. MARCADORES MOLECULARES 067

1. Produção de $\mathrm{D} 49$ e da eristostatina 068

2. Construção da proteína quımérica ECD-Er/APv 077

3. Padronização de Er/APv como marcador molecular 084

3.1. Seletividade de Er/APv para $\alpha \Pi b \beta 3$

3.2. Conservação da atividade fosfatase alcalina de Er/APv 085

3.3. Padronização do teste de dot blot para plaquetas 086

$\begin{array}{lr}\text { DISCUSSÃO } & 089\end{array}$

$\begin{array}{ll}\text { CONCLUSÕES } & 102\end{array}$

REFERÊNCIAS BIBLIOGRÁFICAS 103

$\begin{array}{lr}\text { CURRICULUM VITAE } & 125\end{array}$

$\begin{array}{ll}\text { ANEXO } & 127\end{array}$ 


\section{RESUMO}

As integrinas são proteínas de membrana envolvidas em diversos processos biológicos como embriogênese, inflamação e agregação plaquetária. A alteração de seu padrão de expressão está relacionada com processos patológicos como trombose $e$ câncer, fazendo das integrinas ótimos indicadores da progressão destas doenças. Assim, a integrina $\alpha 2 \beta$ l pode ser considerada como indicadora de angiogênese, sendo expressa nas células endoteliais durante o crescimento de novos vasos. Já a ausência da $\alpha$ llb $\beta 3$ em plaquetas está relacionada com a doença de Glanzmann, caracterizada por uma aggregação plaquetária deficiente, e sua presença em outros tipos celulares está relacionada com processos de metástase e invasão de tecidos. Estas integrinas contêm antagonistas naturais nos venenos de serpentes da família VIPERIDAE: As RGDdisintegrinas bloqueiam a integrina $\alpha \Pi b \beta 3$ e as ECD-disintegrinas bloqueiam a integrina $\alpha 2 \beta 1$. Estas últimas formam parte de metaloproteinases com múltiplos dominios de aproximadamente $50 \mathrm{kDa}$.

Interessados em desenvolver marcadores moleculares para estas integrinas, direcionamos nossos objetivos para: (1) a elucidação da região mínima das ECDdisintegrinas com atividade biológica e (2) construção de biomarcadores para a integrina $\alpha 2 \beta 1$ utilizando a regiăo elucidada, e para a integrina $\alpha \prod b \beta 3$ utilizando uma RGD-disintegrina.

Neste trabalho conseguimos determinar uma região de 49 resíduos na porção Cterminal do dominio ECD-disintegrina da jararagina que reage com um anticorpo neutralizante das atividades hemontágica e de ligação ao colágeno da proteina. Esta região foi subclonada e expressa em fusão com a fosfatase alcalina de $E$. coli, mas não teve funcionalidade como marcador. No entanto, a RGD-disintegrina eristostatina em fusão com a fosfatase alcalina mostrou bifuncionalidade, apresentando tanto atividade disintegrina como atividade catalítica. Além disso, verificamos sua seletividade pela integrina $\alpha$ $\alpha \mathrm{b} \beta 3$ e padronizamos um ensajo direto de dot blot para a presença dessa integrina em plaquetas, com um único passo de incubação. 


\begin{abstract}
Integrins are membrane proteins involved in biological processes such as embriogenesis, inflammation and platelet aggregation. The alteration of their expression pattern is related to pathological disorders such as thrombosis and cancer, making integrins suitable indicators of the progression of these diseases. Thus, the $\alpha 2 \beta 1$ integrin, which is expressed in endothelial cells during capillary growth, may be an indicator of angiogenesis. The absence of $\alpha \Pi b \beta 3$ integrin in platelets is related to Glanzmann disease, characterized by defective platelet aggregation and its expression in other cellular types is related with metastasis and tissue-invasion processes. These integrins contain natural antagonists in venoms from the VIPERIDAE snake family: RGD-disintegrins, which block the $\alpha \nabla b \beta 3$ integrin and ECD-disintegrins, which block the $\alpha 2 \beta 1$ integrin. The latter forming part of multidomain metalloproteinases of approximately $50 \mathrm{kDa}$.

In order to develop molecular markers for integrins, we have directed our objectives at: (1) determining the minimal region of ECD-disintegrins with biological activity and (2) engineering biomarkers for the $\alpha 2 \beta$ I integrin using the previously determined minimal region and for the $\alpha \Pi b \beta 3$ using an RGD-disintegrin.

In this work we have determined a 49-residue region located in the C-terminus of jararhagin ECD-disintegrin domain, which reacts with a neutralizing antibody of hemorrhagic and binding to collagen activities of the protein. This region was subcloned and expressed in fusion with E. coli alkaline phosphatase, but did not present a marker activity. On the other hand, the RGD-disintegrin eristostatin fused to alkaline phosphatase showed bifunctionality, presenting both, disintegrin and catalytic activities. Furthermore, we have characterized its selectivity for the $\alpha M b \beta 3$ integrin and we have standardized a direct dot blot assay with one-step incubation for the presence of this integrin in platelets.
\end{abstract}




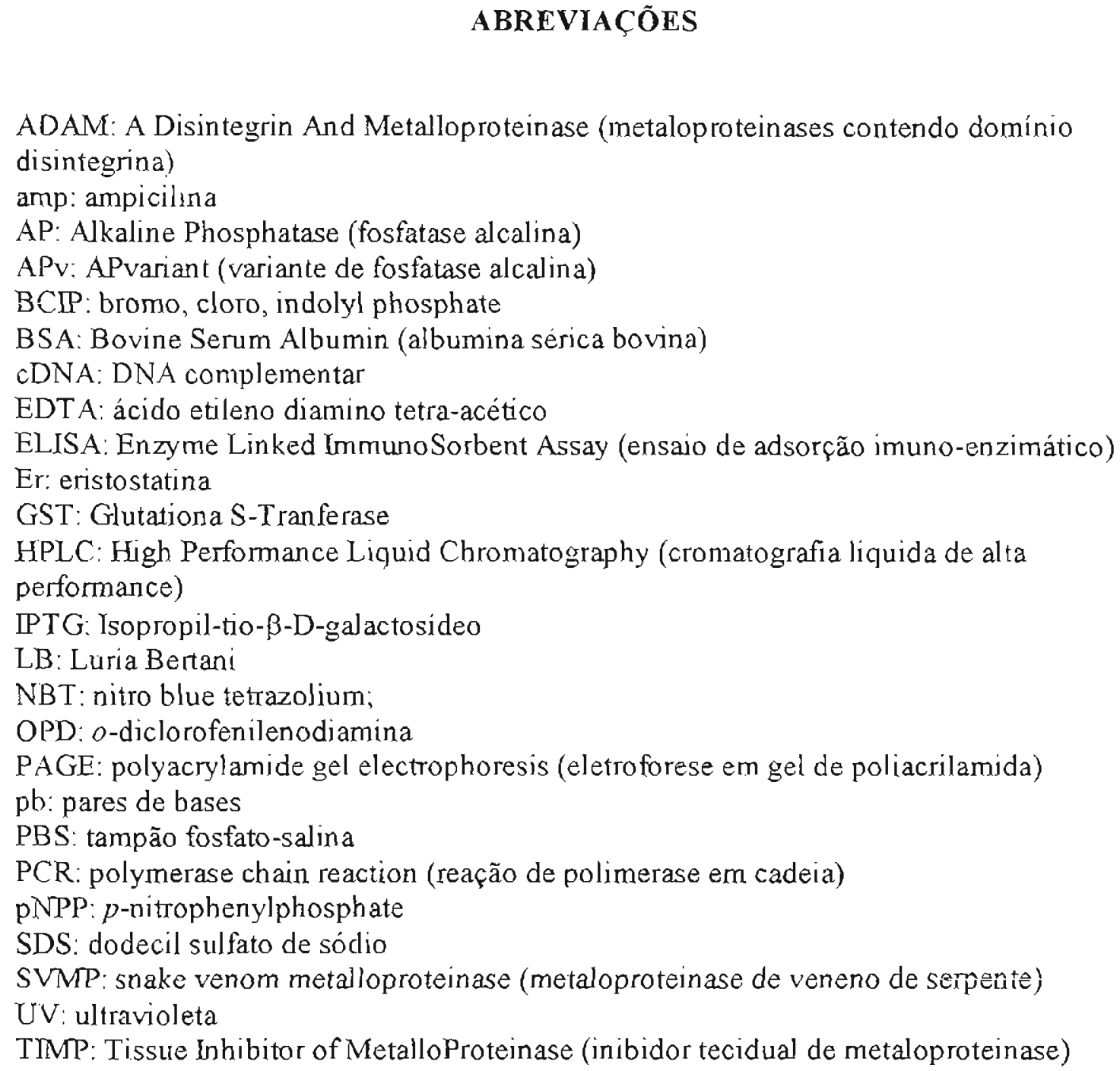

ADAM: A Disintegrin And Metalloproteinase (metaloproteinases contendo domínio disintegrina)

amp: ampicilina

AP: Alkaline Phosphatase (fosfatase alcalina)

APv: APvariant (variante de fosfatase alcalina)

BCIP: bromo, cloro, indolyl phosphate

BSA: Bovine Serum Albumin (albumina sérica bovina)

CDNA: DNA complementar

EDT A: ácido etileno diamino tetra-acético

ELISA: Enzyme Linked ImmunoSorbent Assay (ensaio de adsorção imuno-enzimático)

Er: eristostatina

GST: Glutationa S-Tranferase

HPLC: High Performance Liquid Chromatography (cromatografia liquida de alta performance)

PPTG: Isopropil-tio- $\beta$-D-galactosideo

LB: Luria Bertani

NBT: nitro blue tetrazolium;

OPD: o-diclorofenilenodiamina

PAGE: polyacrylamide gel electrophoresis (eletroforese em gel de poliacrilamida)

pb: pares de bases

PBS: tampão fosfato-salina

PCR: polymerase chain reaction (reação de polimerase em cadeia)

pNPP: p-nitrophenylphosphate

SDS: dodecil sulfato de sódio

SVMP: snake venom metalloproteinase (metaloproteinase de veneno de serpente)

UV: ultravioleta

TIMP: Tissue Inhibitor of MetalloProteinase (inibidor tecidual de metaloproteinase) 


\section{INTRODUÇÃO}

\section{Integrinas}

\section{Caracteristicas estruturais e funcionais}

As células em organismos pluricelulares estão organizadas em tecidos, que por sua vez formam os órgãos. Estas estruturas cooperativas são bastante complexas e a organização das células depende do contato com um complexo de moléculas extracelulares conhecido como matriz extracelular. Toda esta estrutura organizada de matriz, células e tecidos é mantida por moléculas de adesão que se encontram tanto na estrutura da matriz como na membrana celular. Alén de manter este contato, as moléculas de adesão podem fechar espaços entre células, como ocorre no tecido epitelial, e podem transmitir mensagens entre elas mediante sinais quimicos ou elétricos (Alberts e col., 1994). Entre as mass importantes moléculas de adesão da membrana celular estão as integrinas. As integrinas são glıcoproteinas transmembrânicas importantes para a ligação e resposta das células aos componentes da matriz extracelular, podendo mediar as interações bidirecionais entre estes componentes e o citoesqueleto. Também atuam como transdutores de sinal, participando assim de importantes eventos de comunicação e adesão. Dessa forma, as integrinas têm uma participação decisiva nos processos de desenvolvimento a funcionamento dos organismos, participando também de importantes doenças como trombose, inflamação e câncer (Hynes, 1992).

As integrinas são compostas de duas subunidades, $\alpha$ e $\beta$, associadas de forma não covalente. A combinação das cadeias $\alpha$ (19) e $\beta$ (8) gera diversas integrinas de diferentes especificidades (Humphries, 2000). A especificidade e a afinidade da ligação com os diferentes componentes da matriz extracelular será definida segundo o tipo de integrina presente, o número de cópias em cada célula, e também o tipo da célula em que a molécula se apresenta, criando uma grande versatilidade dessa famílía de proteínas na fisiologia dos tecidos (Hynes, 1992).

Estruturalmente, cada subunidade está formada por um domínio extracelular volumoso, uma região transmembrânica e uma cauda citoplásmica A subunidade $\alpha$ corresponde ao produto de um único gene que soffe proteólise resultando em uma cadeia 
pesada e uma cadeia leve ligadas por uma ponte dissulfeto (Phillips e col., 1988). A subunidade $\beta$ apresenta um enovelamento intrincado de pontes dissulfeto (Calvete, 1994) bastante conservado entre as 8 subunidades (Hynes, 1992). As duas subunidades ( $\alpha$ e $\beta$ ) se juntam durante a biosíntese formando o complexo, necessário para a expressão na superficie da célula (Duperray e col., 1989). As integrinas têm sítios de ligação para cátions bivalentes, e estes cátions são necessários para a ligação das integrinas com seus agonistas (Plow e col., 1992). Na cauda citoplasmática, as duas subunidades formam um complexo, un segundo domínio de ligação, que reconhece sinais intracelulares e proteínas do citoesqueleto.

A expressão flogenética de integrinas parece ser geral encontrando-se desde fungos até mamíferos. Sua distribuição tecidual é ampla, sendo expressas praticamente em todo tipo de célula e tecido estudado (Virtanen e col., 1990). Durante o desenvolvimento, as integrinas são onipresentes, regulando os movimentos morfogenéticos e a migração celular e são especialmente expressas durante a gastrulação, neurulação e histogênese (AJbelda e Buck, 1990). Adicionalmente, as integrinas participam de processos fisiológicos como inflamação, cicatrização e agregação plaquetária (Heino, 1993; Rudolph e Cheresh, 1990).

A transdução do sinal onginado pelas integrinas é bidirecionai, isto é: ocorre de dentro para fora e de fora para dentro da célula (Dedhar, 1995). Para que ocorra a adesão célula-célula e/ou célula-matriz extracelular, as integrinas têm que ser ativadas. Esta ativação ocorre mediante estímulo local de mediadores solúveis (hormônios, citocinas, fatores de crescimento, etc.) ou de interfaces sólidas como a matriz extracelular ou outras células. Igualmente importante é que as integrinas sejam inativadas para evitar a adesão celular e ligação a matriz em ocasiões e locais inadequados. A adesão inapropriada pode culminar em trombose ou processos inflamatórios não desejados. É importante que as integrinas tenham um eficiente mecanismo de ativação, uma vež que elas participam de processos rápidos como embriogênese e histogênese (Mizejewski, 1999).

A maior parte das células precisa aderir-se na matriz extracelular para crescer, funcionar e sobreviver apropriadamente (Gui e col, 1995). Durante a formação dos tecidos, a ligação célula-célula e célula matriz é mediada por integrinas. Células epiteliais normais 
podem soffer apoptose quando desprovidas da matriz extracelular (Virtanen e col., 1990). Em cultura celular, a ligação ocorre em estruturas especializadas da membrana denominadas sítios de adesăo focal constituídos de agrupamentos de integrinas firmemente ligados à matriz extracelular (Dedhar, 1995). Sítios de adesão focal menos consistentes estão presentes no tecido epitelial permitindo maior flexibilidade e movimento celular. Estes agrupamentos de integrinas servem como sitios de ligação para fibras intracelulares de actina na superficie citoplasmática da membrana celular, influenciando assim a morfologia celular. Assim mesmo, neste centro de adesão focal tem início uma cascata de sinais que se cruzam com vias de fatores de crescimento, citocinas e quinases (Liu e col., 1997), as últimas incluindo a quinase de adesão focal (FAK) (Burridge e ChrzanowskaWodnicka, 1996). Esta cascata de interações também pode estar ligada a proteinas-G e tirosina quinases. Também tem sido relatado que a forma da célula está diretamente ligada com seu crescimento e taxa de sobrevivência. Dependendo da integrina envolvida os efeitos antiapoptoticos durante o crescimento celular tem sido delineados e descritos (Juliano, 1993; Burridge e Chrzanowska-Wodnicka, 1996; Chen e col, 1997).

\section{Integrinas e Plaquetas}

As plaquetas são particularmente sensiveis à ação das integrinas. A agregação plaquetária ocorre pela interação destas com proteinas de adesão como fibrinogênio, colágeno, fator de von Willebrand, fibronectina e laminına, através de glicoproteínas de membrana especificas, muitas das quais são integrinas $(\alpha \Pi b \beta 3, \alpha 2 \beta 1, \alpha v \beta 3, \alpha 5 \beta 1$ e $\alpha G \beta 1$ ). Entre estas, $\alpha 2 \beta 1$ e $\alpha \operatorname{llb} \beta \hat{3}$ são as mais importantes como mediadores de adesão e agregação plaquetária (Ginsberg e col., 1988). A ativação das plaquetas é decorrente da adesão e pode ser iniciada por diversos estímulos mecânicos e químicos. A adesão ao colágeno do subendotélio através da integrina $\alpha 2 \beta$ l e a presença de trombina estão entre os estimuladores mais fortes da ativação plaquetária. Esta ativação leva à alterações no citoesqueleto resultando em mudanças de forma e degranulação com conseqüente liberação de diversos fatores (ADP, trombina, ATP, $\mathrm{Ca}^{2+}$, GTP, serotonina, fator plaquetário IV, albumina, enzimas hidroliticas, fibrinogênio, fibronectina, fator de von Willebrand, entre 
outras moléculas) e ativação da integrina $\alpha \operatorname{ll} \beta \beta 3$ latenle. Esta ativação depende basicamente da mudança de conformação da integrina (Hughes e Pfaff, 1998). Indiferentemente do agonista e do receptor inicial, a via final consiste na ligação do fibrinogênio à integrina $\alpha$ Imb $\beta 3$ levando à agregação plaquetária (Hynes, 1991). Além disso, estes receptores se agrupam formando chisters que geram eventos de sinalızaçăo de fora para dentro da célula que incluem a reorganização do citoesqueleto da plaqueta (Topol e col., 1999). A integrina $\alpha \Pi b \beta 3$ também particıpa da adesão da plaqueta à fibrina (Lefkovits e col., 1995). A agregação plaquetária é importante pasa a coagulação sanguinea, uma vez que a formação do tampão hemostático evita a hemorragia. Por outro lado, em condições patológicas pode ocorrer a formação de trombos, principais responsáveis por distúrbios cardiovasculares.

A integrina $\alpha \Pi b \beta 3$ é a mais abundante contendo de 60.000 a 80.000 cópias por plaqueta (Wagner e col., 1996). A ausência ou baixa expressão desta integrina está relacionada com a doença de Glanzmann que é caracterizada por um sangramento mucocutâneo recorrente, resultante de uma agregação placjuetária deficiente em resposta a qualquer estímulo fisiológico. Estudos a cerca da doença de Glanzmann serviram de base para o estabelecimento da inibição farmacológica da integrina $\alpha \operatorname{lb\beta 3}$ como terapia antitrombótica (Nurden e Caen, 1974). Outros estudos revelaram ainda novos agonistas para a integrina $\alpha$ llb $\beta 3$ como fibronectina, vitronectina e fator de von Willebrand (Plow e Ginsberg, 1981; Plow e col., 1985) e demonstraram que as interações entre estes e o receptor são mutual mente exclusivas (Plow e col., 1984).

A integrina $\alpha \operatorname{llb} \beta 3$ reconhece duas sequuencias de peptídeos. A seqüência $R G D$, inıcialmente identificada como a região adesiva na fibronectina (Pierschbacher e Ruoslahti, 1984) também está presente no fibrinogênio, fator de von Willebrand e vitronectina. Todos estes ligantes contém como minimo um motivo RGD, enquanto o fibrinogênio contém quatro motivos RGD por molécula. De fato, a seqüência RGD é reconhecida por varias integrinas (Ruoslahti e Pierschbacher, 1986). A outra sequência envolvida na ligação do fibrinogênio à integrina $\alpha \Pi b \beta 3$ é KQAGDV localizada na posição C-terminal da cadeia $\gamma$ do fibnnogênio (Kloczewiak e col., 1983). Esta seqüência é exclusiva do fibrinogênio e é provavelmente o sítio predominante de ligação com a integnina (Farrel e col., 1992). 
A Integrina $\alpha 2 \beta 1$ é a segunda integrina mais importante da plaqueta. É o receptor do colágeno e geralmente é quem desencadeia a agregação plaquetária em resposta a uma lesão (Saelman e col., 1994). Esta integrina é expressa em outros tipos celulares como células endoteliais e está envolvida na angiogênese. Sua diminuição está relacionada com a intemupção do crescimento de capilares e a indução de apoptose (Buda e col., 2003). Além disso, o fator de crescimento do endotélio vascular (VEGF) induz a expressão da integrina $\alpha 2 \beta 1$. Anticorpos anti- $\alpha 2$ inibem a ligação de células endoteliais ao colágeno tipo I e a angiogênese in vivo (Senger e col., 1997)

A interação estrutural da in tegrina $\alpha 2 \beta 1$ com o colágeno foi recentemente elucidada mediante a cristalização do complexo formado entre o domínio l da integrina $\alpha 2 \beta 1$ com a tripla hélice do colágeno (Emsley e col, 2000). O motivo GFOGER previamente determinado por Knight e colaboradores, (2000) parece ser crítico para esta interação. Adicionalmente 3 loops da face superior do dominio I da integrina, que coordenam o ion metálico, também interagem com o colágeno onde o ácido glutâmico do colágeno completa a esfera de coordenação do metal. A comparação com a estrutura do dominio I não ligado revela uma mudança na coordenação do metal e uma reorganização da face superior que juntas criam uma superficie complementar para a ligaçāo com o colágeno.

\section{Integrinas e Câncer}

\subsection{Transformação maligna}

A transformação maligna é caracterizada pela perturbação da organizaçăo do ciroesqueleto, diminuição da adesão e alteração das respostas dependentes de adesão Estudos da expressâo de integrinas em células transformadas sugerem que varias subunidades de integrinas participam tanto positiva como negativamente do fenótipo da célula transformada (Ruoslahti, 1992). Mudanças na expressão de integrinas receptoras de fbronectina têm sido observadas em alguns tipos de fibroblastos. Além disso, alterações nos padrões de expressão de integrinas têm sido observados em inúmeras células malignas (Plantefaber e Hynes, 1989). Em geral, o fenótipo de uma célula transformada pode conter 
diversas alterações nos seus receptores (Akiyama e col., 1990). Por exemplo, altos níveis da integrina $\alpha 5 \beta \mathrm{l}$ parecem estar correlacionados com baixas taxas de transformaçăo em certos tumores. No entanto, um incremento da expressão da integrina $\alpha v \beta 3$ está diretamente relacionado com aumento da malignidade em melanomas (Chan e col, 1991). Como regra geral podemos mencionar a falta de organização espacial da expressão de integrinas em tumores epiteliais Em carcinomas, o arranjo das integrinas é bastante desordenado com una distribuição difusa e menos abundante. Estes desarranjos podem afetar a afinidade da lıgação e estão correlacionados com a desorganização concomitante da estrutura da membrana basal. Niveis reduzidos de expressão das subunidades $\alpha 5, \alpha 3$ e $\propto 2$ têm sido reportados em carcinomas, enquanto um aumento dos níveis da integrina $\alpha 6 \beta 4$ aparece em tumores de cabeça, pescoço e pele (Mizejewski, 1999). Após transformaçăo de linhagens celulares de roedores com o virus de sarcoma, a integrina $\alpha 5 \beta$ I desaparece da superfície celular enquanto os níveis de $\alpha 3 \beta 3$ permanecem constantes (Heino, 1993). Outras mudanças relacionadas com a transformação envolvem aumento da fosforilaçăo, diminuição da afinidade por ligantes, aumento da glicosilação de oligosacarídeos $\mathrm{N}$-ligados nas integrinas. Como mencionado acima, a presença da integrina $\alpha 5 \beta 1$ está associada com um fenótipo celular normal e a super expressão desta integrina pode nomalizar um fenótipo transformado (Chen e col., 1991). Em comparação, células de osteosarcoma humano transformadas com virus requerem o receptor $\alpha 2 \beta 1$ de colágeno. A reorganização da matriz (colágeno) parece ser uma das razões da importância da expressão desta integrina para as células transformadas formarem tumores (Mizejewski, 1999). Em geral, a transformação celular representa um estado pré-canceroso requerendo estratégias preventivas mais que terapias. Uma destas estratégias pode ser a determinação paralela do perfíl de expressão especifica de integrinas em células normais e tumorais do mesmo tecido. 


\subsection{Tumor primário}

Durante o crescimento de tumores primários tem-se observado tanto alterações qualitativas como quantitatıvas do padrão de expressão de integrinas. Muiłas integrinas são super expressas ou não mais expressas enquanto outras são fosforiladas afetando sua interação com o citoesqueleto e com a matriz extracelular (Klein e col., 1991). A formulação de uma assinatura celular da expressão de integrinas de biopsias pode ter potencial como diagnóstico para a detecção tanto da transformação como da progressão de tumores. Por exemplo, a super expressão da integrina a $5 \beta 1$ em células CHO mostra uma redução na malignidade (Cheresh, 1992), enquanto a progressão de melanoma tem sido correlacionada com o aumento das integrinas $\alpha 3 \beta 1$ e $\alpha 4 \beta 1$ (Klein e col, 1991). Outtos estudos mostram também o envolvimento da integrina $\alpha 6 \beta 1$ nesta progressão (Natali e coh., 1992). Embora a expressão das integrinas em células malignas seja alterada com relação as normais, muitos tumores mantêm a expressão normal de pelo menos algumas integrinas. As mudanças no padrão de expressão de integrinas e sua distribuição na superficie celular são especificas para cada tipo de célula tumoral. Carcinomas de mama, próstata e colo de útero mostram uma perda da expressão das integrinas $\alpha 3 \beta 1, \alpha 2 \beta 1, \alpha 5 \beta 1$ e $\alpha 6 \beta 4$; no entanto os sarcomas altamente malignos super expressam a integrina $\alpha 2 \beta 1$, receptor de colágeno, que se acredita estar envolvido em metástases (Ingber e col., 1990). É interessante salientar que a integrina $\alpha \operatorname{llb} \beta 3$, normalmente exclusıva de megacariocitos, é expressa em outros tipos celulares em condições anormais. Chen e colaboradores, (1997) identificaram por RT-PCR a expressão do mRNA correspondente às subunidades $\alpha$ llb e $\beta 3$ em diversas linhagens de células tumorais derivadas de diferentes tecidos de humano, rato e camundongo. Os resultados de PCR foram confirmados por sequenciamento e imunohistoquimica utilizando o anticorpo monoclonal anti- $\alpha$ Ilb $\beta 3$. Em geral, a perda ou ganho de uma integrina em particular parece estar indiretamente implicada na transformação maligna e diretamente envolvida na progressão de tumores e metástase. 


\subsection{Metástase}

A metástase é um processo no qual as células cancerosas se desprendem do lumor primário, entram na circulação e extravasam en sítıos distantes. A entrada da célula tumoral no sistema vascular envolve a perda da adesão e a produção de enzimas proteoliticas para digerir a matriz, formando um tinel através das barreiras dos tecidos. $O$ processo metastático envolve o contacto e separação com diferentes componentes da matriz extracelular e requer mudanças no padrão de integrinas expresso pelas células tumorais. As células tumorais podem migrar efetivamente na matriz e isto depende do funcionamento harmônico das integrinas (Mizejewski, 1999).

Uma vez que as células tumorais entram na circulação estas precisam se aderir ao endotélio para invadir outros tecıdos. Para isto as células tumorais formam conplexos com plaquetas e esta associação junto ao estado hipercoagulado da doença maligna, parece ser essencial para uma metástase bem sucedida (Gould e col., 1990; Huang e col., 1991). A habilidade das células tumorais de induzir agregação plaquetária está bem difundida entre os diversos tipos de cânceres como carcinoma de mana, adenocarcinoma de colo, carcinoma de pulmão, melanomas, etc (Sheu e col., 1995 e 1997). A participação das plaquetas nos processos metastáticos parece resultar da ligação direta das plaquetas com as células tumorais e da liberaçăo de agentes indutores solúveis por parte dos tumores. Estes agentes incluem ativadores clássicos de plaqueta como ADP, catepsina B, proteinases tipo trombina e colágeno (Zhou e col., 1995). Desta maneira, as plaquetas atuariam facilitando to dos os passos intermediários da metástase transvascular incluindo a retenção das células tumorais, interação com o sub-endotélio e extravasamento da microvasculatura. A expressão das integrinas $\alpha \Pi b \beta 3$ e av $\beta 3$ é essencial para a ligação de células de melanoma com plaquetas durante fuxo sanguineo (Felding-Habermann e col., 1996). Além dısso, a in tegrina $\alpha$ Mbß $\beta 3$ é super produzida durante a metástase de células de adenocarcinoma de próstata (Trikha e col., 1998).

O extravasamento é parte do processo de invasão e envolve a adesão de células tumorais na membrana basal, a proteólise parcial de camadas desta membrana seguida da penetração celular através da parte digerida (migração). É interessante notar que as 
integrinas também participam da regulação das atividades das MMPS, metaloproteınases de matriz que degradam a membrana basal. A membrana basal forma um suporte para as células e está composta de um complexo de proteinas que inclui laminina, colágeno e proteoglicanos. De fato a desintegração da organização ou integridade da membrana basal é um marcador histológico chave da transição de um tumor para um estágio invasivo. As células cancerosas produzem, ativam e liberam diversos tipos de proteases que clivam especificamente componentes da matriz extracelular. A degradação localızada da matriz extracelular requer a expressão de proteases especificas e a concomitante expressão de seus insbıdores para prevenir um excesso da degradação da matriz. No caso de MMP2, esta é ativada na superficie celular por um complexo protéico formado por MLMP2, MMP tipo l de membrana (MTl-MMP) e iribidor tecidual de MMP2 (TIMP2). Estudos recentes em melanomas, gliomas e células endotelias angiogênicas indicam que este complexo também inclui a integrina $\alpha v \beta 3$ (Brooks e col., 1996; Deryugina e col, 1997). Inicialmente, a porção C-terminai de MMP2 liga-se a TIMP2 (Fridman e col., 1992) que por sua vez, associa-se com o MT 1-MMP que está ancorado na membrana. MTl-MMP então cliva o pro-domínio N-terminal de MMP2 resultando em uma forma intermediaria capaz de se ligar a integrina $\alpha v \beta 3$ na superficie celular (Deryugina e col, 2000). Esta interação ativa MMP2, na membrana celular das células invasoras abrindo o caminho para estas através da proteólise da matriz extracelular (Brooks e col., 1996). Resumindo, durante a invasão a integrina $\alpha v \beta 3$ funciona não só como um receptor de adesão e migração, mas também como ativador e fxador de proteases que são requeridas para a degradação da matriz extracelular. Uma regulação negativa da interação integrina-protease é requenda para prevenir um excesso de degradação da matriz que pode reduzir a tração celular e inibir a migração. A proteólise é negativamente regulada por $\mathrm{PEX}$, proteína que bloqueia a ativação da protease competindo com MMP2 pela ligação com a integrina $\alpha v \beta 3$ (Brooks e col., 1998). De fato inibidores desta interação suprimem o crescimento de melanomas e gliomas em modelos animais (Silletti e col., 2001; Bello e col., 2001). 


\subsection{Angiogênese}

A angiogênese consiste na iniciação do crescimento de capilares. Durante o crescimento de tumores, novos vasos são recrutados, primeiro na borda e depois dentro da massa intersticial do tumor em crescimento. A massa tumoral em crescimento precisa de uma neovascularização continua, uma vez que a proliferação celular requer o suprimento permanente tanto de oxigênio como de nutrientes. As limitações de oxigênio e nutrientes promovem a indução de novos capilares por parte dos tumores (Vamer e Cheresh, 1996). O controle do crescimento e proliferação de capilares é um alvo potencial para o desenvolvimento de terapias anti-câncer. Agentes antiangiogênicos têm-se mostrado capazes de supimir especificamente o crescimento de tumores sem causar toxicidade sistêmica. Estes agentes também diminuem a tolerância dos tumores a drogas. O efeito tóxico causado por parte dos antiangiogênicos é mínimo em tecidos normais, uma vez que as células endotelıais dos capilares crescem devagar (expressam baixos níveis de integrinas), enquanto os capilares dos tumores multiplicam-se rapidamente e mostram um elevado nivel de expressão de integrinas (Liapis e col, 1997).

O papel das integrinas na angiogênese tumoral pode ser exemplificado por $\alpha v \beta 3 \mathrm{em}$ melanomas. A expressão diferencial desta integrina foi encontrada nos novos vasos formados, mas não nos pré-existentes (Danen e col, 1995). As integrinas vasculares como

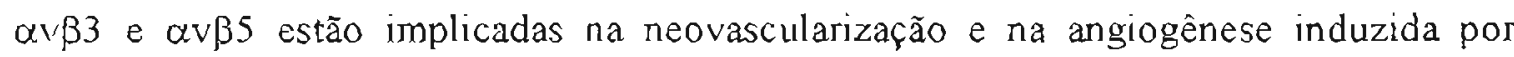
tumores Antagonistas destas integninas como anticorpos monoclonais, peptideos inibidores e oligonucleotideos antisense $\beta 3$ e $\beta 5$ causam a regressào de tumores (Gladson, 1996; Voest, 1996). Deste modo, a inibição da angiogênese atacando o suprimento de sangue e prevenindo o crescimento de novos vasos é uma das áreas mais promissoras de terapias anticancerigenas (Brooks e col, 1995; Boehm 1997). 


\section{Diagnósticos envolvendo integrinas}

As integrinas são ótimos indicadores da progressão de câncer, uma vez que estão envolvidas em todas as etapas, desde a transformafão maligna e crescimento do tumor primário até a metástase e angiogênese. Os métodos mais comuns para detectar integrinas envolvem técnicas de PCR, onde o mRNA das integrinas é amplificado usando primers especificos (Chen e col., 2001). Com a recente tecnologia de cDNAarray o perfil de expressão de integrinas pode ser rapidamente traçado para um determinado tipo de câncer (Hourihan e col., 2003). As integrinas podem ainda ser detectadas por técnicas de imunohistoquímica (Chen e col., 1997), ELISA (Bessos e col, 2003), citometria de fluxo (Leytin e col 1996) e tissue-array mediante o uso de anticorpos monoclonais.

No caso da doença de Glanzmann, onde o mRNA da subunidade $\alpha \Pi b$ é deletado (410-427), técnicas de dot blot utilizando uma sonda marcada de DNA, têm ajudado a diagnosticar a doença (Newman e col., 1991).

\section{Disintegrinas}

Os venenos de serpentes da família HPERIDAE contẽm antagonistas naturais das integrinas denominados disintegrinas. Estas podem estar presentes como peptídeos livres (RGD-disintegrinas) ou formar parte de metaloproteinases complexas com vários dominios (ECD-disintegrinas) que geral mente apresentam intensa atividade hemorrágica. No entanto, ambas formas originam-se de precursores comuns que codificam metaloproteinases da subfamilia das reprolisinas e que incluem um peptídeo sinal, um pro-domínio e um domínio catalítico precedendo o dominio disintegrina, todos bastante conservados entre si

\section{As metaioproteinases de veneno}

As metaloproteinases de veneno (SVMP de Snake Venom Melalloproteinase) podem ser classificadas de acordo com o número de domínios em três classes pnncipais: A classe P.-I que contém apenas o dominio catalítico; a classe P-II que contém o domínio catalítico seguido do dominio disintegrina na posição C-terminal; e a classe P-ID que apresenta o 
domínio catalítico seguido de um dominio ECD-disintegrina e um domínio rico-emcisteínas. Estas três classes como mencionado acima são precedidas de um peptídeo sinal e um pro-domínio (Bjamason e Fox, 1995). Estes mesmos autores sugerem a existência de uma quarta classe, P-IV, onde o domínio ECD-disintegrina estaria unido com dors domínios lectina em tandem através de duas pontes dissulfeto (Takeya e col., 1992). Entretanto, ainda não foi isolado o cDNA deste grupo podendo esta classe ser produto de una modifícação pós-traducional. Na figura 1 podemos observar as 4 classes de SVMP propostas por Bjamason e Fox (1995).

PI

\begin{tabular}{|l|l|}
\hline Pro & Cat \\
\hline
\end{tabular}

PII

\begin{tabular}{|l|l|l|}
\hline Pro & Cat & Dis \\
\hline
\end{tabular}

PJI

\begin{tabular}{|l|l|l|l|}
\hline Pro & Cat & Dis & Cys \\
\hline
\end{tabular}

PIV

\begin{tabular}{|l|l|l|l|}
\hline Pro & Cat & Dis & Cys \\
\hline
\end{tabular}

Fig. 1. Classificação das Metaloproteinases de Veneno (SVMP). As SVMP classificam-se em 4 grupos, PI-IV, dependendo do número de dom Inios presente na protelna madura. Todas estas são geradas como zimogênios e só se ativam após remoçāo do pro-dominio (Pro). As Pl compreendem apenas o domínio catalitico (Cat), enquanto as Pll apresentam este domínio seguido do domínio disintegrina (Dis). Já as Plll, apresentam além dos primeiros domínios, um dominio rico-emcisteínas (Cys). As PIV apresentam adicionalmente dois domínios lectina (Lec) ligados por 2 pontes S-S.

O peptídeo sinal é amplamente conservado entre as SVMPs e tem a função de direcionar a secreção das proteínas à glândula de veneno. Esta seqüência consta de 18 aminoácidos com o sítio putativo de clivagem entre a glicina 18 e a serina 19 (Hite e col., 1992).

As SVMP são expressas como zimogênios no qual o pró-dominio desempenha um papel inibidor. Esta região de 190 resíduos aproximadamente apresenta uma sequêncıa conservada, PKMㄷGVT na qual a cisteína faz parte de um mecanismo denominado cysteine-switch que consiste na ligação do grupo tiol desta ao zinco do sítio ativo 
impedindo a entrada de água ou do substrato, inibindo assim a atividade enzimática. Após processamento do pro-dominio o grupo tiol é deslocado e a enzima adquire atividade catalítica (Jia e col., 1996)

As SVMPs estão evolutivamente relacionadas com as ADAMs ( $\underline{A} \underline{D}$ isintegrin $\underline{\text { And }}$

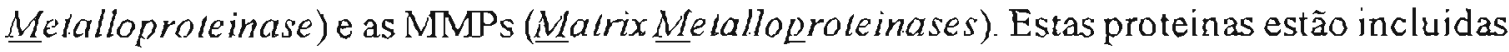
na família M12 de metaloproteinases dependentes de zinco baseadas na estrutura do sítio catalitico e no motivo de ligação ao zinco (Blundell, 1994). O peptídeo sinal e o prodomínio também sào conservados na família Entretanto, diferente das MMPs que apresentam o domínio hemopexina na extremidade C-terminal do domínı catalitico, as ADAMs e as SVMPs apresentam o domínio disintegrina e rico-em-cisteinas. As SVMPS são solíveis enquanto as ADAMs apresentam domínios transmembrânicos e citoplasmáticos, responsáveis por sua localização na superficie celular (Bjarnason e Fox, 1995).

As MMPs estão envolvidas na degradação de componentes da matriz extracelular e participam do remodelamento de tecidos durante a embriogênese, do desenvolvimento e da cicatrização tecidual. Por outto lado, estas proteínas estão envolvidas também em certas patologias como por exemplo artrite, periodontite e metástase de tumores. O domínio hemopexina das MMPs apresenta uma superficie carregada positivamente, com função adesiva, que permite sua interação eletrostática com a porção C-terminal do TIMP que é carregada negativamente (Willenbrock e col, 1993). Por este mecanismo, a pro-MMP é apresentada para uma MMP de membrana (MT-MMP) que irá clivar parcialmente o pródomínio e ativarả a metaloproteinase (Brooks e col., 1996).

Estruturalmente semelhantes, as ADAMs e as SVMPS fazem parte da subfamília das reprolisinas. O termo reprolisinas foi acunhado por Bjamason e Fox (1995), devido ao fato das SVMP terem como fonte serpentes, que são répteis, e também por terem sido as primeiras ADAMs encontradas em tecidos reprodutivos (Blobel e col., 1992 e Wolfsberge col, , 1993). 
O domínio catalítico das ADAMs está envolvido em diversas funções como, por exemplo, na liberação de TNF- $\alpha$ (Black e col., 1997), importante mediador da inflamação; na neurogènese (Loechel e col., 1998); na geração de fibras de colágeno (Millıchip e col., 1998); na manutenção de cartilagens (Tortorella e col., 1999), etc. Porém, em varias $\operatorname{ADAMs}(2-7,11,14,18,22$ e 29) a sequiência consenso al tamente conservada que líga ao zinco está ausente. Estas ADAMrs estão geralmente envolvidas em processos de adesão no qual o domínio disintegnina atua como agonista, promovendo a adesão celular (Almeida e col, 1995). O domínio catalítico é removido durante a maturaçăo, lembrando o processamento de muitas SVMPs da classe P-III (Moura da Silva e col., 2003). Tanto a fertilina $\alpha$ (ADAMI) como a $\beta$ (ADAM2), envolvidas na ligação espermatozóide-óvulo, carecem do dominio catalítico (Blobel e col, 1992). Comparando a homologia estrutural das SVMPs e ADAMs, verificamos que seus domínios ECD-disintegrina apresentam degenerações nos aminoácidos contidos no provável loop de interação com as integrinas, sugerindo que estes domínios podenam diferir quanto a especificidade pelo ligante com as quais elas interagem (Wolfsberg e White, 1996)

\subsection{Estrutura e função das SVMP}

\section{Classe P-I:}

A classe P-I, formada apenas pelo domínio catalítico, apresenta a sequêencia consenso HEXXHXXGXXH conservada na familia M1 2 de metaloproteinases dependentes do íon zinco. A estrutura tridimensional de quatro metaloproteinases da classe P-I foi determinada por cristalografia: adamalisina $\amalg$ de Crotalus adamanteus (Gomis-Ruth e col, 1993), atrolisina-C de Crotahus atrox (Zhang e col., 1994), trimerelisina II de Trimeresurus flovoviridis (Kumasaka e col., 1996) e acutolisina A de Agkistrodon acutus (Gong e col., 1998). Os resultados mostram que são moléculas elipsóides, contendo uma fenda catalítica superficial que separa um subdominio inferior, irregularmente enovelado, de um domínio superior maior, composto de uma follh $\beta$ de cinco fitas e quatro $\alpha$ hélices. O ín zinco se encontra nesta fenda, rodeado de três histidinas (142,146 e 152) e uma molécula de água ancorada no ácido glutâmico 143 , formando assim um tetraedro. O sítio de ligação ao substrato está flanqueado por uma Mel-iurn (Met166), que forma uma base hidrofóbica 
para a molécula de zinco, e duas paredes formadas por uma fita composta dos resíduos 168 172 e uma fita $\beta$ antiparalela do domínio superior (residuos 108-112), mantendo assim a estrutura conformacional da enzima (Stocker e col., 1995).

A maioria das metaloproteinases, tanto hemorrágicas corno não hemorrágicas são fibrino(gênio)líticas e agem clivando preferencialmente a cadeia A $\alpha$ e secundariamente a cadieia B $\beta$ do fibrinogênio (Markland 1998). BaPl, isolada do veneno de Bothrops asper degrada rapidamente a cadeia $A \alpha$ e vagarosamente a cadeia $B \beta$, enquanto não é observada degradação da cadeia y (Gutierrez e col, 1995). A especificidade pelos substratos tem sido testada com caseina, peptídeos de insulina $B$ e substratos de peptideos de fluorescência apagada (Bjamason e Fox, 1995; Takeya e col., 1993). As metaloproteinases hemorrágicas HRIA e HR2a e as não hemorrágicas $\mathrm{H}_{2}$-Proteinase de Trimeresums flavoviridis como Cbfib2 de Crotalus basiliscus clivam preferencialmente o enlace peptídico Pro5 I6/Met517 da cadeia A $\alpha$ do fibrinogênio. Estas enzimas geralmente têm especificidade primaria por substratos de mais de 5 aminoácidos com um resíduo hidrofóbico na posição P1 ' como Leu ou Met (Iwanaga e Takeya, 1993). O ativador de fator $\mathrm{X}$ de Vipera russelli parece requerer uma Arg na posição PI' (Takeya e col., 1993). As atrolisinas B e C de Crotalus atrox clivam a proteína agrecan de cartilagem em dois sitios, Asn34l-Fen342 e Glu373-Ala374 (Tortorella e col., 1998)

\section{Classe P-II (As Disintegrinas):}

As SVMPS da classe P-П sofrem um segundo processamento retirando o domínio catalítico e dando origem às disintegrinas clássicas. As disintegrinas apresentam geralmente uma seqüência RGD responsável pela sua ligação à integrina $\alpha$ Wb $\beta 3$ de plaqueta, inibindo assim a agregação plaquetária. As RGD-disintegrinas podem ser classificadas de acordo com seu tamanho e número de cisteínas em quatro grupos (Miclane e col., 1998). O prımeiro grupo inclui disintegrinas curtas de $41-51$ residuos e 4 pontes dissulfeto. $O$ segundo grupo é o mais abundante e é formado por disıntegrinas médias que contêm aproximadamente 70 resíduos e 6 pontes dissulfeto. O terceiro grupo está formado por disintegrinas longas com 84 resíduos e 7 pontes dissulfeto. O quarto grupo é composto de disintegrinas diméricas, onde cada unidade contém aproximadamente 67 residuos e 10 
cisteinas envolvidas na formação de 4 pontes intracadeia e 2 pontes intercadeia (Calvete e col., 2000-A).

A atividade inibitória das disintegrinas é conferida pela estrutura primária do loop e é dependente da formação das pontes dissulfeto apropriadas (McLane e col., 1996). Estudos de ressonância magnética nuclear (RMN) mostram um loop flexivel que sobressai de 14 $17 \AA$ da estrutura da proteína com o tripeptideo RGD no seu ápice (Adler e col., 1991; Saudek e col., 1991; Senn e Klaus, 1993). Na maior parke das disintegrinas monoméricas o motivo funcional é o RGD (McLane e col., 1998). Estas disintegrinas ligam-se com diferente afinidade e seletıvidade às integrinas $\alpha \mathrm{mb} \beta 3, \alpha v \beta 3$ e $\alpha 5 \beta \mathrm{I}$ que reconhecem a seqüência RGD nos seus ligantes naturais. A seletividade é conferida pelos resíduos adjacentes ao motivo RGD e os aminoácidos da porção C-terminal (WierzbickaPatynowski e col., 1999). A barbourina, a bitistatina e a eristostatina apresentam um al to grau de especificidade pela integrina $\alpha \Pi b \beta 3$ de plaqueta (McLane e col., 1998). Estas três disintegrinas têm em comum a presença do resíduo triptofano (W) depois do ácido aspártico (D). Estudos de modelagem da eristostatina mostram que resíduos hidrofóbicos, como a valina 25 e o triptofano 30 , aumentam significativamente a largura do loop, conferindo-the especificidade por esta integrina (McLane e col., 1996).

As disintegrinas diméricas apresentam maior variabilidade no seu motivo funcional. A disintegrina heterodimérica EC3 de Echis carinatus apresenta a seqüência VGD e MLD, mostrando-se um potente inibidor das integrinas $\alpha 4 \beta 1, \alpha 4 \beta 7$ e $\alpha 9 \beta 1$ (Marcinkiewicz e col., 1999-A e 2000). Já a disintegrina heterodimérica EMFl0, isolada do veneno de Eristocophis macmahoni, apresenta a sequência MGDW importante para a inibição seletiva da integrina $\alpha 5 \beta 1$ (Marcinkiewicz e col., 1999-B) No caso de CC 8 , purificada do veneno de Cerastes cerastes, o motivo WGD aumenta o efeito inibitónio sob as integrinas $\alpha$ Mb $\beta 3$, $\alpha v \beta 3$ e $\alpha 5 \beta 1$ (Calvete e col., 2002).

Todas as disintegrinas apresentam um loop de 11 resíduos com o ácido aspártico conservado na sexta posição. Estudos de cristalografia da porção extracelular da integrina $\alpha v \beta 3$, em complexo com um peptídeo cíclico contendo a seqüência RGD, mostram que o oxigênio da carboxila do Asp penetra na fenda do dominio $\beta$ A e participa de uma rede de interações polares (Xiong e col., 2002). Estes dados suportam a conservação deste resíduo 
em todas as disintegrinas. No entanto, a obtustatina, isolada recentemente do veneno de Vipera lebetina obtusa. apresenta uma seqüência KTS com importância funcional nesta regsião. Esta disintegrina, a menor até hoje descrita com 4 l residuos e 8 cisteínas, não só difere na conservação dos resíduos do loop como na extensão deste, apresentando 9 residuos em lugar dos 11 conservados em todas as disintegrinas, inclusive as diméricas (Moreno-Murciano e col., 2003). Esta diferença parece conferir-lhe seletividade pela integrina $\alpha \mid \beta 1$, inibindo a ligação desta ao colágeno $\Gamma$ com um $\mathrm{IC}_{50}$ de $2 \mathrm{nM}$.

O potencial das disintegrinas como drogas tem sido amplamente avaliado. Tanto a tngramina como a rodostomina têm se mostrado potentes inibidores da agregação plaquetaria induzjda por células tumorais (Gould e col., 1990; Sheu e col., 1997). No entanto, as duas disintegrinas utihzam diferentes vias para alcançar este objetivo. A trigramina é um antagonista específico da interação com células de câncer de mama, enquanto a rodostomina mibe a agregação plaquetária antagonisando a interação com células de adenocarcinoma de colo (Gould e col., 1990). No caso de células cancerosas de mama, próstata e colo, a agregação plaquetária induzida pelo fator ativador de trombina pode ser inibida tanto por trigramina como rodostomina (Gould e col., 1990; Huang e col., 199 1; Sheu e col., 1997). A rodostomina inibe adicionalmente a angiogênese decorrente do fator de crescimento de fibroblasto suprimindo o crescimento de tumores (Yeh e col., 2001). Disintegrinas como a contortrostatina e a salmosina inibem a neovascularização bloqueando as integrinas $\alpha 5 \beta \mathrm{l} \in \alpha \mathrm{v} \beta 3$, respectivamente. Adicionalmente, a contortrostatina inibe a progressão de càncer de mama ligando as integrinas e bloqueando a adesão das cèlulas cancerosas à vitronectina e fibronectina da matriz extracelular (Zhou e col., 2000). A salmosina inibe o crescimento de células epiteliais após cirurgia de catarata. Isto é muito importante, uma vez que estas células podem causar uma opacificação capsular pós-cirúrgica (Kim e col, 2002)

As disintegrinas têm sido avaliadas como drogas anti-trombóticas. 0 desenvolvimento de drogas inibidoras da agregação plaquetária dirigidas contra a integrina $\alpha \operatorname{llb} \beta 3$ é muito importante uma vez que a inibição deste receptor previne a agregação independentemente da via metabólica iniciada Estas drogas têm um amplo espectro de uso incluindo prevenção primária de doença cardiovascular e prevenção de eventos coronários 
em pacientes de alto risco. Devido a seu tamanho e conformação, as disintegrinas não são usadas diretamente como drogas, mas têm servido como base para o desenho de antagonistas moleculares de baixo peso molecular. Eptifibatide (Integrelin) é um peptideo cíclico baseado na barbourina, apresentando a sequêencia KGD (Phillips e Scarborough, 1997). Foi aprovado pela FDA para uso em intervenção coronária percutânea e síndromes coronárias e é atualmente manufaturado por COR Therapeutics, Schering Plough. Outros inibidores como Tirofiban (Merck and $\mathrm{Co}$ ) baseado na seqüência RGD são peptídeo mıméticos aumentando o tempo de vida na circulação. A substituição da arginina (R) por um grupo amidino ou benzamidino e o uso de D-aminoácidos incrementam a resistência à degradação enzimática (Cox e col., 1994).

A eristostatina, isolada do veneno de Eristocophis macmahoni é a disintegrina mais potente inibindo a agregação plaquetária com um IC so de 59 nM (McLane e col., 1994). É uma das mais seletivas ligando-se preferencialmente à integrina $\alpha$ lb $\beta 3$ de plaqueta. Esta disintegrina, uma das menores com 49 resíduos e 4 pontes dissulfeto, já foi produzida em E. coli mantendo sua seletividade e potência (Wierzbicka-Patynowski e col., 1999). A enstostatina tem se mostrado capaz de inibir o crescimento de células de melanoma Bl6F 1 após o extravasamento (Morris e col, 1995). Assim mesmo, esta disintegrina inibiu fortemente a colonização do pulmão de camundongos após injeção de células de melanoma MV3 e foi verificada a ligação da eristostatina com estas células (Danen e col., 1998). Ademais, a eristostatina aumenta a susceptibilidade da linhagem SBcl 2 de melanoma por células tipo-NK TALL-104 (McLane e col., 200I).

\section{Classe P-IrY:}

As metaloproteinases de veneno da classe P-Wl contêm as proteínas mais hemorrágicas (Bjarnason e Fox, 1994). A presença dos domínios ECD-disıntegrina/ricoem-cisteínas parece potencialızar esta atividade, no entanto não se tem evidência direta de sua participação. A hemorragia é comumente relacionada com a atividade proteolítica, uma vez que a quelaçăo do ion zinco, abole tan to a proteólise como os efeitos hemorrágicos (Bjarnason e Fox, 1994). É interessante notar que os venenos apresentam também metaloproteinases desprovidas de ativdade hemorrágica (Markland, 1998; Willis e Tu, 
1988). Alguns trabalhos têm identificado resíduos no dominio catalítico que parecem essenciais para exercer esta atividade (Hite e col., 1992; Takeya e col., 1990).

As metaloproteinases hidrolisam os componentes da membrana basal e este efeito está estreitamente relacionado com a hemortagia (Osaka e col., 1973). Tem sido claramente demonstrado que estas proteinas degradam laminina, fibronectina, colágeno IV e nidogênio in vitro (Rucavado e col., 1995 e 1999; Bjamason e col., 1988; Baramova e col., 1989 e 1990; Maruyama e col, 1992) e a membrana basal in vivo (Ownby e col., 1978; Moreira e col., 1994). A hemorragia parece estas estreitamente relacionada com a hidrólise do colágeno IV, uma vez que metaloproteinases não hemorrágicas não conseguem hidrolisar esta molécula (Mashiko e col., 1998). Adicionalmente as metaloproteinases agem nas células endoteliais dos capilares ocasionando lesões através das quais os eritrócitos e outros componentes do sangue escapam ao espaço intersticial (McKay e col., 1970; Ownby e col., 1978).

Diferentemente das disintegrinas clássicas, o domínio ECD-disintegrina das SVMPs da classe P-III apresenta uma sequiência ECD conservada no lugar do motivo RGD, conferindo-Ihe assim atividade in izitória da agregação plaquetária dependente do colágeno. Esta classe de metaloproteinases também pode sofrer um segundo processamento, dando ongem a um fragmento correspondente aos domínios ECD-disintegrina e rico-em-cisteinas. Desta maneira, no veneno podemos encontrar a forma composta dos domínios catalitico, ECD-disintegrina e rico-em-cisteínas e o produto de proteólise correspondente aos dois últmos dominios (Moura da Silva, 2003).

Entre as SVMPs da classe P-MI, a jararagina vem sendo estudada por vários grupos. Esta metaloproteinase isolada do veneno de Bothrops jararaca cliva a cadeia Aa do fibrinogênio na porção C-terminal dando origem a um fragmento de 285-290 kDa que carece da seqūência RGD (572-574) que se liga às plaquetas. No entan to, a seqüência RGD (95-97) localizada na porção N-terminal da cadeia Ao e a KQAGDV localizada na parte Cterminal da cadeia $\gamma$, permanecem intactas. Desta maneira a agsegação plaquetária dependente de ADP não é afetada. Mesmo assim, a formação do coágulo de fibrina é defeituosa com uma baixa polimerizacão dos monômeros de fibrina (Kamiguti e col., 1994). 
A jararagina é multifuncional sendo responsável pela atividade hemorrágica e pela inibição da agregação plaquetária dependente do colágeno. Adicionalmente, a jararagina tem sido relacionada a outras funções como no processamento do Pro-TNF $\alpha$ (Moura da Silva e col., 1996), na indução da migração de leucocitos e liberação de citocinas (Clissa e col., 2001; Costa e col., 2002.) e na clivagem do plasminogênio gerando angiostatina (Ho e $\operatorname{col}, 2002)$.

Embora o domínio catalítico seja comumente responsabilizado pela atıvidade hemoırágica, e os domínios ECD-disintegrına/rico-em-cisteínas pela inibição da agregação plaquetária, existem evidèncias que os domínios atuam sinergistucamente potencializandose uns aos outros. Kamiguti e colaboradores (1996), mostraram que a jararagina cliva a subunidade $\beta 1$ da integrina $\alpha 2 \beta 1$ confirmando a participação do domínı catalitico na inıbição da agregação plaquetárı. Alem disso, anticorpos resultantes da imunização de camundongos com o cDNA correspondente aos domínios ECD-disintegrina/rico-emcisteínas neutralizaram a atividade hemorrágica da jararagina (Harrison e col., 2000) demonstrando-se assim a participação destes dominios nesta atividade.

A inibição da agregação plaquetária dependente de colágeno por parte da jararagina e as demais metaloproteinases do tipo P-IL é um fato, no entanto a região ou dominio responsável por esta atividade e o mecanismo de açăo não estão esclarecidos e ainda existem controvérsias nos dados da literatura. Da jararagina sabemos que injbe a agregação plaquetária induzida por colageno com um $\mathrm{IC}_{50}$ de $40 \mathrm{nM}$ (Kamiguti e col, 1996) e a ligação de células $\alpha 2$-K562 expressando a integrina $\alpha 2 \beta$ I ao colágeno (Moura da Silva e col., 2001). Com respeito às regiões responsáveis pela inibição da agregação plaquetána dependente de colágeno, sabe-se que o fragmento recombinante cortespondente aos domínios ECD-disintegrina/rico-em-cisteínas conserva atividade inibitória da agregação plaquetária (Moura da Silva e col, 1999). Trabalhos utilizando peptideos sintéticos mostraram que o motivo de adesão está localizado no loop correspondente ao domínio ECD-disintegrina (Kamiguti e col, 1997; Zhou e col., 1996). No entanto, Jia e colaboradores (2000) mostraram atividade de inibição da agregação plaquetána por parte do domínio rico-em-cisteinas recombinante da atrolisina A. Ainda mais, Ivaska e colaboradores (1999), mostraram que o peptídeo TRKKHDNAQ correspondente aos 
resíduos 241-249 do domínio catalítico da jararagina se liga no domínio I da integrina $\alpha 2$, Jigante do colágeno tipo I, e seria uma das regiões responsáveis por inibir a agregação plaquetária dependente de colágeno.

A jararagina tem se mostrado eficaz também na inibição da progressão de células de melanoma (Correa e col., 2002). É interessante que a quelação do íon zinco do sítio catalítico da jararagina com ortofenantrolina não diminuiu esta atividade, o que sugere que os dominios ECD-disintegrina/rico-em-cisteínas da jararagina estejam desempenhando um papel fundamental nesta inibição

Concluindo, a jararagina é uma metaloproteinase multıfuncional composta de três domínios: catalítico, ECD-disintegrina e rico-em-cisteinas, no entanto não exste um consenso entre a estrutura e a funçāo dos domínjos desta proteína. Dos dados da literatura podemos concluir que os domínios ECD-disintegrina e rico-em-cisteinas são os responsáveis pela ligação ao colágeno (Zhou e col, 1996) e à integrina $\alpha 2 \beta 1$ (Kamiguti e col., 1997) e ainda existem evidências indiretas que esta região potencializa as atividades hemonágica e proteolítica da jararagina (Harrison e col., 2000) O esclarecimento da função dos domínios ECD-disintegrina e rico-em-cisteinas e sua participação nas atividades hemorrágica e proteolítica da jararagina são essenciais para melhor entender a estrutura e função desta molécula. Do mesmo modo, a determinação da porção que liga à integrina $\alpha 2 \beta 1$ servirá de base para o desenho de inibidores e para a construção de marcadores moleculares para esta integrina. Com base nisto temos definido nossos objetivos. 


\section{OBJETIVOS}

- Determinar a regiăo dos dominios ECD-disintegrina/rico-em-cisteinas responsável pela atividade disintegrina das SVMP da classe P-JII utilizando a jararagina como modelo. Para tanto, utilizaremos duas abordagens principais que consistem na clonagem e expressão de fragmentos do cDNA que codifica os domínios disintegrina e rico-em-cisteínas da jararagina e a avaliação da atividade biológica. Paralelamente esses fragmentos serão utilizados para o mapeamento dos epitopos reconhecidos por anticorpos monoclonais que neutralizam as atividades biológicas da toxina.

- Construir marcadores moleculares para integrinas baseados na eristostatina e em motivos funcionars dos dominios ECD-disintegrina e rico-ent-cisteinas. Estes marcadores serão construidos utilizando o sistema pLIP de expressão que resul ta na produção da proteina recombinante em fusão com a fosfatase alcalina de $E$. coli, que pode ser usada então como marcador molecular. 


\section{MATERIAL E MÉTODOS}

\section{l. MATERIAL:}

\section{REAGENTES:}

\subsection{Enzimas:}

- Fosfatase alcalina bacteriana, Gibco BRL

- Trombina, Novagen

- DNA polimerase de Termus aquaticus (Taq), Applied Biosystems.

- DNA polimerase de Pirococcus sp. (Pfx), Invitrogen.

- Endonuclease de restrição BamH I, Invitrogen.

- Endonuclease de restrição Dpn I, New England Biolabs.

- Endonuclease de restrição EcoR I Invitrogen.

- Endonuclease de restrição Not I, New England Biolabs.

- Endonuclease de restrição Sfi I, New England Biolabs.

- Enzima de ligação T4 DNA ligase, Boehringer.

\subsection{Marcadores:}

- Marcador de massa molecular de DNA Lambda clivado com Hind III originando os fragmentos de $23130,9416,6557,4361,2322,2027,564$ e 125 pb, Invitrogen.

- Marcador de massa molecular de DNA e calibrador de concentração apresentando os fragmentos de $2000(50 \mathrm{ng} / \mu \mathrm{L}), 1200(30 \mathrm{ng} / \mu \mathrm{L}), 800(20 \mathrm{ng} / \mu \mathrm{L}), 400(10 \mathrm{ng} / \mu \mathrm{L}), 200$ $(5 \mathrm{ng} / \mu \mathrm{L})$ e $100 \mathrm{pb}(2,5 \mathrm{ng} / \mu \mathrm{L})$, lnvitrogen.

- Marcador de massa molecular de DNA ladder apresentando os fragmentos de i500, $1000,900,800,700,600,500,400,300,200$ e 100 pb, Promega

- Marcador de massa molecular de proteínas para SDS-PAGE correspondente a 94; 67; 43; 30; 20,1 e 14,4 kDa Amersham Biosciences

- Marcador de massa molecular de proteinas para Western blottung correspondente a 104 ; $81 ; 47,7 ; 34,6 ; 28,3$ e 19,2 kDa. Amersham Biosciences.

\section{KITS:}

- Purificação de plasmideos:

- Quantum Prep Plasmid Miniprep Kit, Biorad.

- Quantum Prep Plasmid Midiprep Kit, Biorad.

- Purificação de fragmentos de DNA do gel:

- Gene Clean II kit, Bio 10I Inc.

- Mermaid kit, Bio 101 Inc. 
- Purificação de produtos de PCR:

- Concert Rapid PCR Purification System, Life Technologies.

- Quantificação da atividade fosfatase alcalina:

- Alkaline Phosphatase Substrate Kit, Biorad.

- Dosagem de proteínas:

- Reativo de Bradford.

\section{ANTICORPOS:}

- Anti-jararagina: anticorpo policlonal de coelho produzido contra a jararagina nativa purificada (Moura da Silva e col., 1999).

- Anti-GST: anticorpo policlonal de coelho produzido contra a GST recombinante.

- Anti-TRxJD9: anticorpo policlonal de coelho produzido contra o fragmento recombinante correspondente aos domínios disintegrina e rico em cisteínas da jararagina (jararagina-C) em fusão com tioredoxina (Moura da Silva e col., 1999).

- Anti-AP: Anticorpo policlonal de coelho anti-fosfatase alcalina de E. coli. Chemicon Intemational, Inc. (Cat. Num. AB 1204).

- MAJar3: o anticorpo monoclonal munno MAJar3 forma parte de uma série de anticorpos desenvolvidos contra a jararagina nativa no mestrado de Isabelle Tanjoni. É do isotipo IgGI, tem uma $K_{D}$ de $1.9 \times 10^{-9}$, reconhece um epítopo conformacional e unibe a ligação jararagina-colágeno, a atividade hemorágica da jararagina in vivo além de inibir a agregação plaquetária dependente de colágeno (Tanjoni e col., in press).

\section{SOLUÇÕES:}

- Antrcoagulante para plaquetas: EDTA 2\%.

- Anticoagulante para sangue: citrato de sódio $3,8 \%$.

- MTT [3-(4, 5-Dimethylthiazol-2-yl) 2,5 diphenyl tetrazolium bromide], Sigma. Diluir $10 \mathrm{mg}$ de MTT em $2 \mathrm{~mL}$ de PBS. Esta solução é adicionalmente diluída em meio de cultura $(1: 10)$.

- Fosfato de potássio: 0,17 $\mathrm{M} \mathrm{KH}_{2} \mathrm{PO}_{4}, 0,72 \mathrm{M} \mathrm{K}_{2} \mathrm{HPO}_{4}$.

- Meio de cultura para células CHO 45\% de DMEM, 45\% de F12 e 10\% de soro fetal bovino (FCS).

- Meio LB (por litro): $10 \mathrm{~g}$ peptona, $5 \mathrm{~g}$ de extrato de levedura, $10 \mathrm{~g}$ de $\mathrm{NaCl}, \mathrm{pH} 7,0$ Autoclavar a $120^{\circ} \mathrm{C}$ por $20 \mathrm{~min}$.

- Meio 2YT (por litro): $16 \mathrm{~g}$ triptona, $10 \mathrm{~g}$ extrato de levedura, $5 \mathrm{~g} \mathrm{NaCl}, \mathrm{pH} 7,0$ Autoclavar a $120^{\circ} \mathrm{C}$ рог $20 \mathrm{~min}$. 
- Mero SOB (100 mL): $2 \mathrm{~g}$ peptona, 0,5 g Extrato de levedura, 0,05 $\mathrm{g} \mathrm{NaCl}, 0,25 \mathrm{~g}$ $\mathrm{MgCl}_{2}+6 \mathrm{H}_{2} \mathrm{O}$, Água deionizada até $100 \mathrm{~mL}, \mathrm{pH} 7,0$. Autoclavar a $120^{\circ} \mathrm{C}$ por $20 \mathrm{~min}$

- Meio SOC (100 mL) $98 \mathrm{~mL}$ de meio SOB, $2 \mathrm{~mL}$ de Glicose 1 M estéril.

- Meio TB (por litro): $900 \mathrm{~mL}$ de água deionizada, $12 \mathrm{~g}$ peptona, $24 \mathrm{~g}$ de extrato de levedura, $4 \mathrm{~mL}$ de glicerol. Autoclavar a $120^{\circ} \mathrm{C}$ por $20 \mathrm{~min}$ e adicionar $100 \mathrm{~mL}$ de fosfato de potássio autoclavado quando esfriar.

- Meio TSB (Tryptic Soy Broth) (por litro): $17 \mathrm{~g}$ de triptona, $3 \mathrm{~g}$ de soytona, $5 \mathrm{~g}$ de extrato de levedura, $5 \mathrm{~g}$ de $\mathrm{NaCl}$ e $2,5 \mathrm{~g}$ de $\mathrm{K}_{2} \mathrm{HPO}_{4}$, p. 7,5 . Autoclavar a $120^{\circ} \mathrm{C}$ por 20 $\min$

- Solução de sacarose: sacarose 20\%, Tris-HCl 0,3 M, pH 8, EDTA 1 mM

- Solução estoque de BCIP (5-Bromo,-4-Chloro-3-Indolyl Phosphate): dissolver uma pastilha de BCIP, contendo $25 \mathrm{mg}$ de substrato (Sigma), em 0,5 $\mathrm{mL}$ de dimetilformamida $100 \%$.

- Solução estoque de NBT (Nitro Blue Tetrazolium): dissolver uma pastilha de NBT, contendo $10 \mathrm{mg}$ de substrato (Sigma), em $1 \mathrm{~mL}$ de água deionizada

- Tampão de NBT/BCrP: Tris 0,1 M, NaCl 0,1 M, $\mathrm{MgCl}_{2} 5 \mathrm{mM}, \mathrm{pH} 9,5$.

- Substrato NBT/BCIP. $330 \mu \mathrm{L}$ da solução estoque de NBT + $10 \mathrm{~mL}$ do tampão $+33 \mu \mathrm{L}$ da solução estoque de BCIP.

- Solução de lavagem para Westem e dot blot: Tris-salina (Tris $10 \mathrm{mM}$ e $\mathrm{NaCl}$ 0,15 M, $\mathrm{pH} 7,5)$.

- Solução bloqueadora para Western e dot blot (5\% de leite em pó desnatado Molico, Nestlé em Tris-Salina).

- Solução salina tamponada com fosfato (PBS): $\mathrm{NaCl} 140 \mathrm{mM}, \mathrm{KCl} 2,7 \mathrm{mM}, \mathrm{Na}_{2} \mathrm{HPO}_{4}$ $10 \mathrm{mM}, \mathrm{KH}_{2} \mathrm{PO}_{4} \mathrm{l}, 8 \mathrm{mM}, \mathrm{pH} \mathrm{7,4}$

- Solução de lavagem para ELISA (PBS contendo 0,1\% de Tween 20, Sigma)

- Solução bloqueadora para ELISA (PBS contendo 1\% de BSA).

- Tampão da trombina: Tris $20 \mathrm{mMl}$ pH 8,4, $\mathrm{NaCl} 150 \mathrm{mM}, \mathrm{CaCl}_{2} 2,5 \mathrm{mM}$.

- Tampão de eletroforese TAE (50X): Tris $2 \mathrm{M}, 57,1 \mathrm{~mL}$ de acido acético glacial, EDT A $0,1 \mathrm{M}, \mathrm{pH} 8,0$.

- Tampão de lavagem para plaquetas: $\mathrm{NaCl} 140 \mathrm{mM}, \mathrm{NaHCO}_{3} 10 \mathrm{mM}, \mathrm{KCl} 2,55 \mathrm{mM}$, $\mathrm{Na}_{2} \mathrm{HPO}_{4} 0,92 \mathrm{mM}, \mathrm{MgCL}_{2} 2,1 \mathrm{mM}$, citrato de sódio $25 \mathrm{mM}$, glicose 0,55 mM, BSA $0,35 \%, \mathrm{pH}=6,5$.

- Tampão de amostra SDS-PAGE: Tris/HCl $125 \mathrm{mM}, \mathrm{pH} 6,8$, contendo 2,5\% de SDS, 2,5\% de 2-mercaptoetanol, 20\%de glicerol, $1 \mathrm{mM}$ de PMSF, $1 \mathrm{mM}$ de TLCK, $4 \mathrm{mM}$ de EDTA e $0,05 \%$ de azul de bromofenol.

- Tampão de corrida SDS-PAGE: glicina $196 \mathrm{mM}$, SDS $0.1 \%$, Tris-HCl $50 \mathrm{mM}$, pH 8.3 . 
- Solução descorante SDS-PAGE: 5\% de metanol e 7,5\% de acido acético.

- Tampão de transferência Western blot: Tris $25 \mathrm{mM}$, glicina $190 \mathrm{mM}$, Metanol $20 \%$.

- Alfa-4-cloro-naftol dissolver o comprimido de $30 \mathrm{mg}$ em $10 \mathrm{~mL}$ de metanol. Adicionar $3 \mathrm{~mL}$ desta solução a $17 \mathrm{~mL}$ de tris-salina e na hora de revelar adicionar $20 \mu \mathrm{L}$ de $\mathrm{H}_{2} \mathrm{O}_{2}$.

- Solução cromógena para ELISA: $1 \mathrm{mg}$ de OPD por mL de tampăo citrato $0,2 \mathrm{M}, \mathrm{pH} 5$ mais $\mathrm{H}_{2} \mathrm{O}_{2} 0,06 \%$.

\section{VETORES:}

- pGEX-4T-1 (Amersham Biosciences). Este sistema desenvolvido por Smith e colaboradores (1988), já foí utilizado com sucesso na clonagem e expressão de diversas disintegrinas (Chang e col., 1997, Wierzbicka-Patynowski e col., 1999) e de fragmentos recombinantes correspondentes aos domínios ECD-disintegrina e jico-em-cisteínas de ADAMs (Bigler e col, 2000). A principal vantagem deste sistema sobre outros sistemas bacterianos é a possibilidade de se obter uma proteína de fusão facılmente purificável em condições não denaturantes. Este vetor de 4969 pb contém uma origem de replicação do plasmídeo $p B R 322 ;$ o gene $A p^{R}$, que codifica a $\beta$-lactamase, que confere ao hospedeiro resistência a ampicilına; um gene lac $I^{q}$ (que codifica um inibidor do promotor lac); um promotor lac $l$ (promotor misto, contendo seqüências dos promotores lacUV5 e trp, responsável por um alto nivel de expressão protéica e induzivel por IPTG (Boer e col., 1983), imediatamente seguido pela seqüência que codifica a porção efetora da enzima glutationa S-transferase de Schistosoma japonicum (que se liga especificamente a glutationa (Simons e col., 1977); uma seqüência que codifica o tetrapeptídeo alvo da trombina (Chang, 1985), que permite a separação da proteina de interesse da proteína GST e um sítio de clonagem múlttpla (fig. 2). 


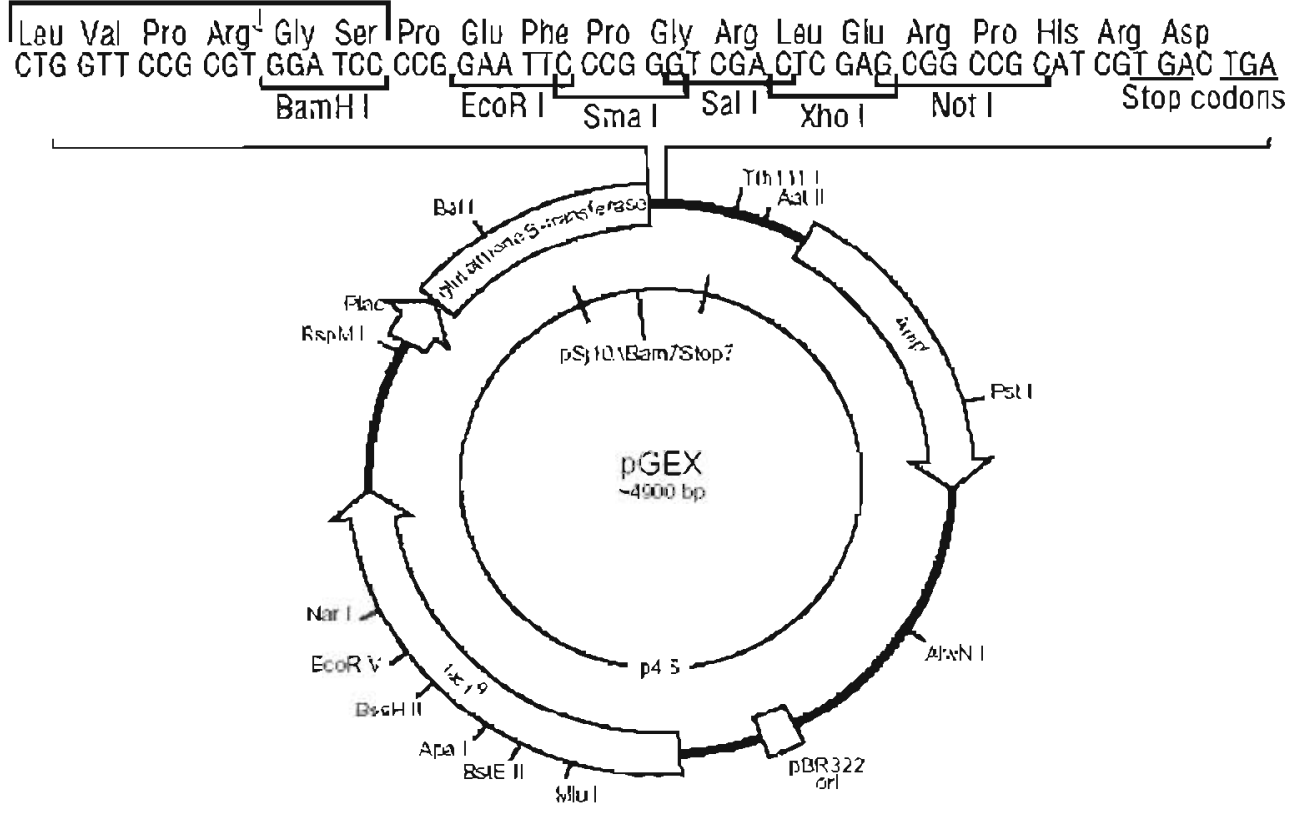

Flg. 2. Diagrama do vetor PGEX-4T-1 onde podemos observar o gene da glutationa S-transferase precedendo o sftio de clivagem com trombina e o sitio de clonagem múltipla. Também podemos observar os genes que codificam a $\beta$-lactamase $\left(A m p^{r}\right)$ e o repressor lac I. O sitio de origern de pBR322 e o sitio do promotor Ptac também estão representados.

- pLiP6-GN (Muller e col., 1999). Este vetor cedido pelo Dr. Frederic Ducancel (Département d'Ingénierie et d'Études des Protéines - CE.A Saclay, Gif-Sur-Yvette, France) permite a expressão periplásmica de proteínas exógenas em fusão com uma variante de fosfatase alcalina de E. coli (APv). A diferença da enzima original a APv apresenta duas mutações nos resíduos 153 e 330 que the conferem 10 vezes mais atividade catalítica permitindo um melhor sinal. O vetor pLIP6-GN de $6448 \mathrm{pb}$ apresenta uma única opção de clonagem nos sítios para Sfi I e Not I. Esta região está inserida no gene pho $A$ da fosfatase alcalina na posição correspondente aos resíduos $+6 \mathrm{e}$ +7 da proteína madura. A clonagem nesta região permite o correto processamento do peptídeo sinal da fosfatase alcalina após a secreção no periplasma e a restituição do gene PhoA, o qual se encontra fora de fase de leitura no pLIP6-GN selvagem. Isto possibilita a triagem de colônias azuis positivas em placas de L-agar contendo o 
substrato cromógeno da fosfatase alcalina BCIP. Este vetor é regulado pelo promotor tac (Boer e col., 1983), inducível por IPTG e codifica a enzima $\beta$-lactamase que the confere resistência a ampicilina. A figura 3 mostra o mapa do vetor pLIP6-GN com os sítios de clonagem indicados pelas setas e a estratégia de clonagem mostrando a restituição da fase de leitura do gene $P h o A$.

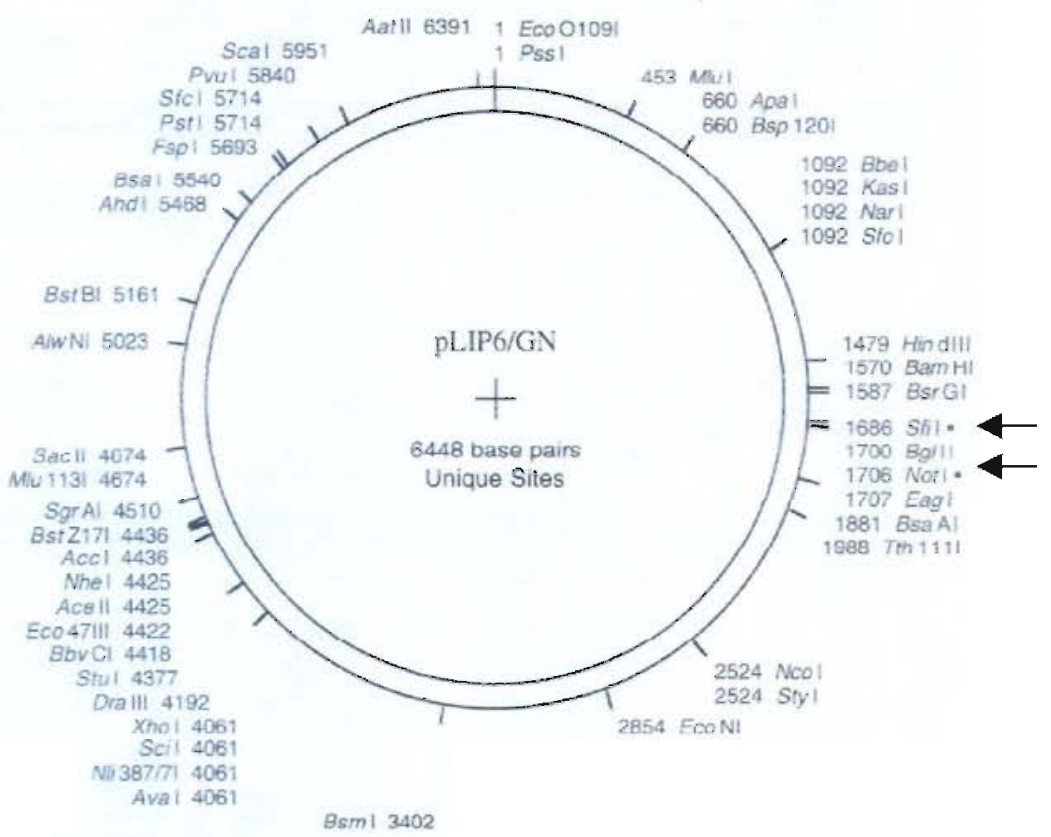

Gene PhoA antes da clonagem:

Sfi I Not I

cggacaccagaaatgccGGCCCAGCCGGCCaagatctGCGGCCGCagttctggaaaa . . . . aacgggtga

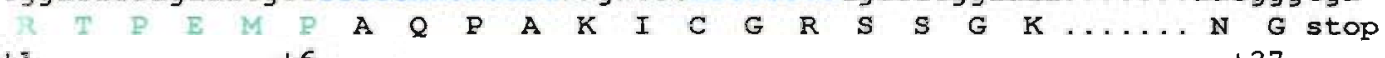
$+\mathrm{I}+\mathrm{H} \quad+37$

Gene PhoA após a clonagem:

inserto

cggacaccagaaatgccGGCCCAGCCGGCCnnnGCGGCCGCagttctggaaaaccgg. . . . . ctgaaataa

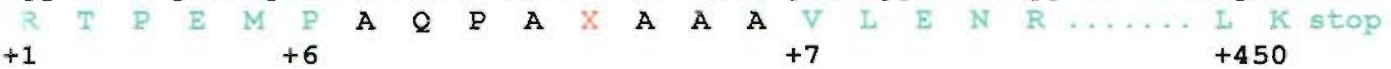


Fig. 3. Diagrama do vetor PLIP6-GN onde podemos observar os sítios únicos de restrição para Sfi I e Not I. Embaixo está representada a estratégia de triagem do vetor: antes da clonagem o gene PhoA da fosfatase alcalina se acha fora de fase de leitura originando uma proteina truncada de 37 residuos. Após a clonagem de $3 n$ pares de bases (vermelho) o gene PhoA restabelece sua fase de leıtura dando origem à fosfatase alcalina de $E$. coli. (verde). Em azul estão representados os sítios de restrição para Sffl e Not I.

- pLIP5-GN. Este vetor a diferença do pLIP6-GN apresenta o gene da fosfatase alcalina PhoA em fase de leitura expressando a APv após indução com $\mathrm{PTG}$.

- pLIP5m. Vetor derivado do pLIP5-GN apresentando mutações no sítio catalítico do gene PhoA. Após indução com PTG a fosfatase alcalina de E. coli (APm) é expressa no periplasma mas sem atividade enzimática

\section{CEPAS BACTERLANAS:}

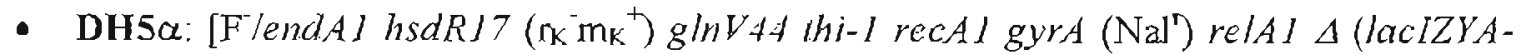
argF) U169 deoR ( $\$ 80$ dlac $(\operatorname{lac} Z) M / 5)]$ bactéria de clonagem utilizada na amplificação de plasmideos e transformaçăo de clones.

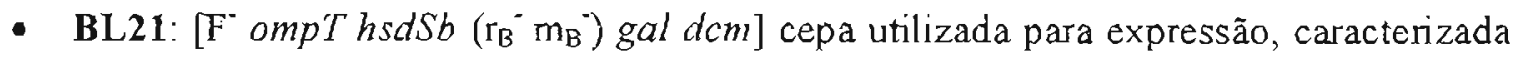
por possuir reduzidas quantidades de proteases citoplásmicas.

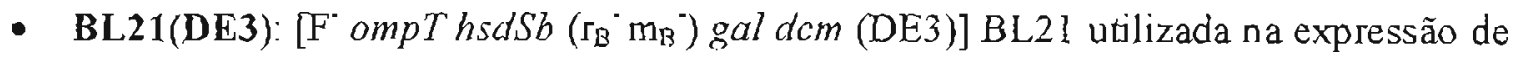
plasmídeos com o promotor $\mathrm{T} 7$

- CC118: [F" $\triangle$ (aralew)7679 araD139 $\Delta$ lacX74 gale galK $\triangle p h o A 20$ thi rpsE rpoB $\arg E(A m) \operatorname{rec} A$ l appR] Com deleção no gene $p h o A$ que codifica para a fosfatase alcalina de E. coli.

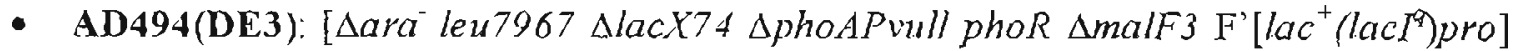
$\operatorname{tr} B:$ :kan(DE3)] Com deleção no gene $\operatorname{tx} B$ que permite a formação de pontes dissulfeto no citoplasma de $E$. coli. Utilizada na expressão de plasmídeos com o promotor $T 7$.

\section{LINHAGENS CELULARES:}

- Células de ovário de hamster chinês (CHO) expressando basalmente a integrina $\alpha 5 \beta 1$ (K1) (ATCC, Rockville, MD).

- Células de ováno de hamster chinês (CHO) transfectadas com o gene que codifica as subunidades da integrina $\alpha$ Ib $\beta 3$ (A5) (Dr. Ginsberg, Scripps Research Institute)

- Células de ovário de hamster chinês (CHO) transfectadas com o gene que codifica as subunidades da integrina avß3 (VNRC3) (Dr. Ginsberg, Scripps Research Institute). 
- Células entrociticas K562 expressando a integrina a5ß1 (ATCC, Rockville, MD).

- Células eritrocíticas $\alpha 2$ K562. K562 transfectadas como gene que codifica a subunidade $\alpha 2$, expressando a integrina $\alpha 2 \beta 1$

\section{PROGRAMAS:}

- ProtParam tool: foi utilizado na análise físico-quimica das proteínas. http://us.expasy.org/tools/protparam.html

- Primer tool: utilizado no design de oligonucleotídeos http//Biotools.umassmed edu/bioapps/primer3 www.cgi

- Manipulate a DNA sequence: serve para inverter uma seqüència de DNA ou obter sua seqüência complementar.

http://arbl.cvmbs.colostate.edu/molkit/manip/index.html

- WebCutter 2.0: foi utilizado para verificar os sítios de clivagem das enzimas de restrição em uma seqüència de DNA.

http://www firstmarket.com/culter/cut2.html

- Translate tool: foi utilizado para a decodificação do DNA em aminoácidos.

http://us.expasv.org/tools/dna.html

- ClustalW (Thompson e col., 1994): este programa fol usado para alinhar as seqüências de aminoácidos.

http.//npsa-pbil.ibcp.fr/coi-bin/npsa automat.pl?page=npsa clustalw.html

- Dialign: programa utilizado no alinhamento de sequeências de DNA, inclusive sequeências com sua respectiva tradução em aminoácidos. http://bibiserv. techfak. uni-bielefeld.de/cgi-bin/dialign_submit

- Chromas 1.45: este programa foi utilizado para visualizar os cromatogramas das sequềncias

Connor McCarthy, School of Health Science, Griffith University.

Queensland, Australia

- Graph Pad Instat tm: este programa for utilizado para analise de regressão linear, desenho de curvas e cálculo de novos valores.

Copyright (C) 1990-93 Graph Pad Software V2.01

Dr. Cipolla-Neto, U. de São Paulo 930675 S. 


\section{MÉTODOS:}

\section{AMPLTFICAÇÃO DOS FRAGMENTOS DE DNA POR PCR:}

Os fragmentos de DNA foram amplificados por PCR. Foram realizadas reações de $50 \mu \mathrm{L}$ com 50-100 ng de DNA molde, $2 \mu \mathrm{L}$ de cada oligonucleotideo $(1 \mu \mathrm{M}), 5 \mu \mathrm{L}$ de tampão da Taq DNA polimerase 10X, $5 \mu \mathrm{L}$ de dNTP $(2 \mathrm{mM}), 0,4 \mu \mathrm{L}$ de Taq DNA polimerase (IU/ $\mu \mathrm{L}$ ) e o volume foi completado com água deionizada para $50 \mu \mathrm{L}$. O programa utilizado foi: 1 ciclo de desnaturação de $94^{\circ} \mathrm{C}$ por 2 min., 30 ciclos com desnaturação a $94^{\circ} \mathrm{C} \mathrm{x} 1$ min.; anelamento a $55^{\circ} \mathrm{C} \times 1 \mathrm{~min}$; e extensão a $72^{\circ} \mathrm{C} \times 2 \mathrm{~min}$, e um ciclo final para extensão dos fragmentos de $72^{\circ} \mathrm{C}$ par $5 \mathrm{~min}$.

Quando utilizada a $P f x$ DNA polimerase empregamos o dobro de concentração de ohgonucleotídeos e uma temperatura de extensão de $68^{\circ} \mathrm{C}$.

\section{PURIFICAÇÃO DOS FRAGMENTOS DE DNA:}

\subsection{Extração com fenol/clorofórmio:}

As extrações com fenol/clorofórmio foram fettas com o seguinte protocolo: A cada amostra de DNA contida em um determinado volume de água, foram adicionados 0,6 volumes de fenol e homogeneizadas em vortex. Posteriormente, foram adicionados 0,6 volumes de clorofórmio, homogeneizados novamente em vortex e centrifugados a $10.000 \mathrm{~g}$ por $\mathrm{l}$ min em microcentrifuga. A fase aquosa foi separada e submetida a uma nova extraçăo. A esta se adicionou l volume de clorofórmio. Esta solução foi homogeneizada no vortex, centrifugada a $10.000 \mathrm{~g}$ e a fase aquosa transferida para outro tubo. Esta extração com clorofómio foi repetida mais uma vez para completa remoção do fenol. O sobrenadante final foi precipitado com 2,5 volumes de etanol 100\% ع 0,1 volumes de acetato de sódio $3 \mathrm{M}, \mathrm{pH} 5,2$, e mantido a $-20^{\circ} \mathrm{C}$ overnight. A mistura foi então centrifugada a $10.000 \mathrm{~g}$ por 15 min, o sobrenadante descartado e o pellet foi lavado rapidamente com 4 volumes de etanol 70\% gelado e secado ao vácuo. O pellet foi ressuspenso em água deionizada. 


\subsection{Concert Rapid PCR Purification System:}

Este sistema permite a rápida purificação de fragmentos de DNA. Este método se baseia na ligação do DNA a uma resina acoplada a um filtro. Após duas lavagens com o tampão de lavagem o DNA é eluído em água deionizada obtendo-se uma soluçăo pura.

\section{ELETROFORESE EM GEL DE AGAROSE:}

As eletroforeses foram feitas em géis de agarose com concentrações entre 0,8 e 1,2\% de agarose, em tampão TAE. Para a corrida, foi utilizado o mesmo tampão ao qual foram adicionados $20 \mu \mathrm{l}$ de Brometo de Etídio $10 \mathrm{mg} / \mathrm{mL}$ (Sambrook e col., 1989). Para os géis analíticos foi utilizado agarose tipo I da Amresco e para os gèis preparativos foi utilizada agarose tipo VII da Sigma. O padrão de peso molecular usado foi o DNA do fago lambda digerido com Hind 00 ou o ladder descritos na lista de reagentes. As corridas foram feitas a 80 volts com um máximo de 300 mAmp.

\section{EXTRAÇÃO DE UM FRAGMENTO DE DNA A PARTIR DE UM GEL DE AGAROSE LOW MELTING:}

A banda foi cortada no transiluminador em ondas longas de UV para não danificar o DNA (Zimmermann e col., 1998) e colocada em um tubo de prova para ser pesada. O DNA foi então purificado por extração fenólica ou pelo kit Gene Clean

\subsection{Purificação com fenol:}

Eșta técnica se baseia na extração da agarose com fenol. Na amostra foram adicionados 500 $\mu \mathrm{L}$ de TAE $1 \mathrm{X}$ e incubou-se em barho maria a $70^{\circ} \mathrm{C}$ por $15 \mathrm{~min}$ (até a agarose liquefazerse). A extração com fenol foi realizada como especificado anteriormente para um meio liquido. 


\subsection{Purificação utilizando o kit Gene Clean II:}

A purificação baseia-se em uma matriz de sílica especial, glass milk, que liga DNA de dupla e simples fita de $200 \mathrm{pb}$ a $20 \mathrm{kpb}$ sem ligar contaminantes, garantındo a recuperação de até $80 \%$ do DNA No caso de fragmentos menores, utilizamos o Mermaid kut que permite a purificação de oligômeros, de 10 a 200 pb.

No tubo de prova com a amostra foram adicionados 3 volumes de $\mathrm{NaI}$ e incubados a $55^{\circ} \mathrm{C}$ por 5 min ou até a dissolução da agarose. Logo após, foi adicionada a suspensão de matriz levando em conta que $1 \mu \mathrm{L}$ desta liga até $2 \mu \mathrm{g}$ de DNA. A reação foi mantida em gelo por 5 min agitando-se a cada 2 min para assegurar que a matriz se mantenha ressuspensa e se ligue à maior quantidade de DNA possível. A reação foi então centrifugada por 5 seg a $10.000 \mathrm{~g}$, o sobrenadante descartado e a matriz foi lavada 3 vezes com 50 volumes de tampão de lavagem gelado, utilizando o mesmo tempo e veiocidade de centrifugação. $O$ pellet foi ressuspenso em um volume de água deionizada igual ou maior ao de matriz utilizado (dependendo da concentração de DNA necessária) e manádo a $56^{\circ} \mathrm{C}$ por $3 \mathrm{~min}$ para permitir a separação do DNA da matriz. Para formar um precipitado sólido, o tubo for centrifugado por 30 seg a $10,000 \mathrm{~g}$ e o sobrenadante foi cuidadosamente colhido.

\section{DIGESTÕES COM AS ENDONUCLEASES DE RESTRIÇÃO:}

As digestões foram realizadas com o tampão apropriado para cada enzima e à temperatura de reação adequada como especificado pelo fabricante. A quantidade de tampão (l0X) foi adicionada levando em conta o volume total da reação e a quantidade de enzima fos adicionada levando em conta a quantidade de DNA presente, partindo da premissa que uma unidade (U) de enżima cliva $1 \mu \mathrm{g}$ de DNA em uma hora de reação à temperatura correspondente. Foram utilizadas entre 1 e 3 unidades por $\mu g$ de DNA em reações de 3 a 4 horas. 


\section{REAÇÕES DE LIGAÇÃO:}

As reações de ligação foram feitas em volumes de $15 \mu \mathrm{L}$. As reações incluem o vetor e o inserto na relação molar de $1: 5,2 \mathrm{U}$ da T4 DNA ligase, o tampão da ligase (10X) correspondente a $10 \%$ do volume total da reação e $1 \mu \mathrm{L}$ de ATP $10 \mathrm{mM}$. As reações foram realizadas a $16^{\circ} \mathrm{C}$ por $18 \mathrm{~h}$.

\section{PREPARAÇÃO DE BACTÉRIAS COMPETENTES:}

Uma colônia fresca de bactéria foi cultivada em meio $\mathrm{LB}$ durante a noite a $37^{\circ} \mathrm{C}$ sob agıtação. No dia seguinte, $100 \mu \mathrm{L}$ desta cultura foram inoculados em $10 \mathrm{~mL}$ de $\mathrm{LB}$ e incubados nas mesmas condições até atingir a fase logaritmica de crescimento $\left(A_{600}=0,5\right.$ 0,8). Em seguida, a cultura foi centrifugada durante $10 \mathrm{~min}$ a $1600 \mathrm{~g}$ e $8^{\circ} \mathrm{C}$ O peller foi ressuspenso em $5 \mathrm{~mL}$ de $\mathrm{CaCl}_{2} 50 \mathrm{mM}$ gelado e mantida em gelo durante $30 \mathrm{~min}$. Após esse periodo, as bactérias foram centrifugadas durante $10 \mathrm{~min}$ a $4500 \mathrm{~g}$ e $4^{\circ} \mathrm{C}$; $\mathrm{o}$ sobrenadante foi descartado e as bacténas ressupensas em $1 \mathrm{~mL}$ de $\mathrm{CaCl}_{2} 50 \mathrm{mM}$ gelado. As células competentes foram aliquotadas em volumes de $100 \mu \mathrm{L}$ e utilizadas imediatamente na transformação.

\section{TRANSFORMAÇÃO:}

A mistura de ligaçâo ou os plasmideos foram usados na transformação das bactérias competentes. A $100 \mu \mathrm{L}$ de células competentes, foram adicionados $1,7 \mu \mathrm{L}$ de $\beta$-Mercapto etanol (1:20) e a mistura foi mantida em gelo por $10 \mathrm{~min}$. Logo após, foi adicionado o produto da ligação o qual foi incubado com as bactérias competentes por $30 \mathrm{~min}$ em gelo, seguindo-se por uma rápida incubação de 55 seg a $42^{\circ} \mathrm{C}$. Logo em seguida, as amostras foram colocadas no gelo por $2 \mathrm{~min}$. As células foram então incubadas com meio SOC por 1 $h$ a $37^{\circ} \mathrm{C}$ sob agitação, e centrifugadas. O pellet foi ressuspenso com $50 \mu \mathrm{L}$ do sobrenadante, semeado em placas com $100 \mu \mathrm{g} / \mathrm{mL}$ de ampicilina e incubado overnight a $37^{\circ} \mathrm{C}$. 
No caso das bactérias transformadas com fragmentos de DNA clonados nos vetores pLIP, as bactérias foram semeadas em placas contendo além da ampicilina, 100 بMM IPTG e 40 $m g / m L$ de $B C I P$.

\section{PREPARAÇÃO DO DNA DO PLASMÍDEO:}

Os plasmídeos foram purificados usando os kits Quantum prep plasmid miniprep e midiprep da Biorad, seguindo as recomendações do fabricante. Este se baseia na separaçâo do DNA por uma matriz de exoesqueleto de dióxido de silicone de diatomáceas, que tem alta afinidade pelo DNA e permite uma fácil resuspensão e eluiçào. A seguir apresentamos o protocolo de minipreparação: Uma colônia de bactéria contendo o plasmídeo foi incubada en $5 \mathrm{~mL}$ de meio TB overnight a $37^{\circ} \mathrm{C}$. O meio foi centrifugado por $30 \mathrm{seg}$ a $10.000 \mathrm{~g}$ e pellet foi resuspendido em $200 \mu \mathrm{L}$ de solução de resuspensão por meio do vortex. As células foram então lisadas com $250 \mu \mathrm{L}$ de solução de lise, invertendo o tubo várias vezes ate aparecer uma solução clara e viscosa. As proteinas e o DNA cromossomal foram precipitados invertendo o tubo 10 vezes com $250 \mu \mathrm{L}$ de solução de neutralização. A mistura for centrifugada a $10.000 \mathrm{~g}$ x $5 \mathrm{~min}$., o pellet descartado, e o sobrenadante incubado sobre agitação com $200 \mu \mathrm{L}$ de solução de matriz. Esta mistura foi transferida para outro tubo contendo um filtro e filtrada por centrifugação a $10.000 \mathrm{~g} \times 30 \mathrm{seg}$. O filtrado foi descartado e a resina retida pelo filtro foi lavada com $500 \mu \mathrm{L}$ de solução de lavagem, por centrifugação a $10.000 \mathrm{~g}$ por $30 \mathrm{seg}$ no mesmo tubo. O filtrado foi descartado e o procedimento repetido com centrifugação a $10.000 \mathrm{~g}$ por 2 min. O filtro foi então colocado em um novo tubo e o DNA foi eluído da matriz com $100 \mu \mathrm{L}$ de água deionizada previamente aquecida a $70^{\circ} \mathrm{C}$ e centrifugado a $10.000 \mathrm{~g}$ por 30 segs. O material eluido for estocado a $-20^{\circ} \mathrm{C}$.

\subsection{Otimização da preparação de plasmídeo:}

Este método foi adaptado do Large scale plasmid preparation (Sambrook e col., 1989). Uma colônia de ti. coli DH5 $\alpha$ contendo o plasmídeo desejado foi inoculada em $3 \mathrm{~mL}$ de TB mais $100 \mu \mathrm{g} / \mathrm{mL}$ de ampicilina e cultivada a $37^{\circ} \mathrm{C}$ sob agitaçăo até atingir uma $\mathrm{A}_{600}$ de 0,6 . Um volume de $2,5 \mathrm{~mL}$ desta cultura foi inoculado em $50 \mathrm{~mL}$ de $\mathrm{TB}$ contendo 100 
$\mu \mathrm{g} / \mathrm{mL}$ de ampicilina, e cultivado durante $2,5 \mathrm{~h}$ a $37^{\circ} \mathrm{C}$ sob agitação. Após este tempo foram adicionados $170 \mathrm{\mu g} / \mathrm{mL}$ de cloranfenicol, cultivando por $12-16$ horas. A midipreparação foi realizada com $40 \mathrm{~mL}$ do meio utilizando o kit Quantum prep plasmid midiprep segundo o protocolo descrito acima, respeitando-se as proporções dos reagentes. O DNA foi eluído em $600 \mu \mathrm{L}$ de água deionizada a $70^{\circ} \mathrm{C}$ e estocado a $-20^{\circ} \mathrm{C}$.

\section{DETERMINAÇ̃̃O DA CONCENTRAÇÃO DE DNA:}

Uma aliquota de $10 \mu \mathrm{L}$ de DNA foi diluida em $90 \mu \mathrm{L}$ de água deionizada. A absorbânçia foi determinada nos seguintes comprimentos de onda: $260 \mathrm{~nm}$ (correspondente ao pico de absorção de RNA e DNA) e $280 \mathrm{~nm}$ (correspondente ao pico de absorção de proteínas). A concentração de DNA dupla fita foi determinada considerando que $A_{260}=1$ comesponde a $50 \mathrm{ng} / \mu \mathrm{L}$. Para avaliar o grau de pureza do DNA obtido, o quoeficiente das absorbâncias a $260 / 280 \mathrm{~nm}$ foi calculado. Um resultado perto de 2 representa um alto grau de pureza (Sambrook e col., 1989)

\section{TRLAGEM DAS COLÔNLAS:}

\subsection{Por PCR direto:}

As reações foram feitas utilizando $5 \mu \mathrm{L}$ da cultura bacteriana como molde, $1 \mu \mathrm{L}$ de cada oligonucleotídeo ( $1 \mu \mathrm{M}), 2,5 \mu \mathrm{L}$ de tampão da Taq DNA polimerase $10 \mathrm{X}, 2,5 \mu \mathrm{L}$ de dNTP ( $2 \mathrm{mM}), 0,2 \mu \mathrm{L}$ de Taq DNA polimerase ( $(U / \mu \mathrm{L})$ e foi completado com água deionizada para $25 \mu \mathrm{L}$.

\subsection{Por PCR após mini-prep:}

As reações foram feitas após mini-prep, utilizando-se $2 \mu \mathrm{L}$ de plasmideo como molde.

Em ambos os casos, as reações foram feitas em volumes de $25 \mu \mathrm{L}$ utilizando o programa especificado acima. 


\section{SEQÜENCIAMENTO:}

Os seqüenciamentos foram feitos no Centro de Biotecnologia do Instituto Butantan pelo método de terminação de cadeia por dideoxinucleotídeos (Sanger e col., 1977). As reações de PCR foram feitas em volumes de $20 \mu \mathrm{L}$ utilizando $500 \mathrm{ng}$ do plasmideo, 3,2 pmol de primer, $2 \mu \mathrm{L}$ de Big Dye 2 (Applied Biosystems) e $6 \mu \mathrm{L}$ de tris $200 \mathrm{mM}$ pH9,0 e $5 \mathrm{mM}$ $\mathrm{MgCl}_{2}$ ). As reações de seçüenciamento foram feitas no seqüenciador $A B I 3100$ da Applied Biosystems, utilizando eletroforese capilar.

\section{MUTAGÊNESE SÍTIO-DIRIGIDA:}

13:1. Baseado na técnica do kit QuinkChange ${ }^{T h}$ site-directed mutagenesis da Stratagene (Catalog $\$ 200518$ ).

Este sistema nos permite inserir, deletar ou substituir uma ou mais bases diretamente no vetor de clonagem (DNA de dupla fita), eliminando a subclonagem e as diversas transformaçôes dos métodos convencionais. O procedimento utiliza um vetor dupla fita contendo o inserto de interesse e dois oligonucleotídeos contendo as mutações desejadas. Cada um dos oligos é complementar a una das fitas de DNA. Após alguns ciclos (12-18) de extensão utilizando uma DNA polimerase de alta fidelidade $(P f x)$ varias cópias do vetor contendo a mutação desejada são geradas. Utilizando a en donuclease Dph I (só digere DNA metilado) digeriremos a fita de DNA parental para garantir a transfornaçăo só com o vetor mutado. A mutação é confirmada por seqüenciamento dos clones.

13.2. Baseado na técnica de Megaprimer (Picard e col., 1994).

Construimos um megaprimer contendo os nucleotideos a serem mutados para a posição 3". $\mathrm{Na}$ posição $5^{\circ}$ utilizamos o primer Eris5Sfi. Após amplificação por $\mathrm{PCR}$, o produto foi clonado no vetor de escolha.

\section{EXPRESSÃO:}

Uma colônia de E. coli transformada com o plasmídeo de interesse foi semeada em LB contendo $100 \mu \mathrm{g} / \mathrm{mL}$ de ampicilina, mantendo a cultura overnight a $37^{\circ} \mathrm{C}$ sob agitação. As 
células foram semeadas em uma diluição 1:50 em meio TSB ou 2YT suplementados com $100 \mu \mathrm{g} / \mathrm{mL}$ de ampicilina. As culturas foram incubadas a $37^{\circ} \mathrm{C}$ sob agitação até chegarem a fase logaritmica $\left(A_{6 n 0}=0,5-0,8\right)$. Neste momento foi adicionado IPTG para uma concentração de $100 \mu \mathrm{M}$ e a cultura foi mantida por $4 \mathrm{~h}$ a $37^{\circ} \mathrm{C}$. As culturas então foram submetidas a extração celular ou periplásmica.

\section{EXTRAÇÃO CELULAR:}

A extração celular foi realizada nos clones expressando a proteina de interesse no citoplasma bacteriano. Um volume de cultura foi centrifugado a $3000 \mathrm{~g}$ por $5 \mathrm{~min}$. $\mathrm{O}$ sobrenadante foi descartado e o pellet foi ressuspenso em 0,1 volumes de tampão PBS ou Tris-HCl. As bactérias foram então lisadas por sonicação ou por french press

\section{LISE BACTERIANA}

\subsection{Lise por sonic ação:}

A sonicação se baseia na quebra das bactérias por ultra-som. Utilizou-se uma amplitude de $65 \mathrm{~Hz}$ e pulsos de 5 seg durante 8 min. Os produtos sonicados foram então centrífugados a $3000 \mathrm{~g}$ por $5 \mathrm{~min}$. e o sobrenadante foi estocado a $-20^{\circ} \mathrm{C}$.

\subsection{Lise por french press:}

Esta técnica se baseia na lise das bactérias ao serem submetidas a altas pressões passando por um orifícıo estreito regulado por uma válvula. A pressão utilizada foi de 1500 psi. Os produtos foram centrifugados a $3000 \mathrm{~g}$ por $5 \mathrm{~min}$. e os sobrenadantes colhidos e estocados a $-20^{\circ} \mathrm{C}$. 


\section{EXTRAÇĀO PERIPLÁSMICA:}

Este protocolo descrito por Ducancel e colaboradores (1989), permite a obtenção das proteínas exportadas ao penplasma por choque osmótico Um volume de cultura foi centrifugado a $5000 \mathrm{~g}$ por 5 min e o sobrenadante descartado. O pellet foi ressuspenso em 0,1 volumes de solução de sacarose e incubado a temperatura ambiente por $10 \mathrm{~min}$. Logo após as células foram centrifugadas a $5000 \mathrm{~g}$ por $5 \mathrm{~min}$ e o sobrenadante descartado $O$ pellet foi então ressuspenso em 0,1 volumes de $\mathrm{MgCl}_{2} 0.5 \mathrm{mM}$ gelado, incubado em gelo por 10 min. sob leve agitação. A solução foi submetida a centrifugação a $10.000 \mathrm{~g}$ por 10 min., a $4^{\circ} \mathrm{C}$, o pellet descartado e o sobrenadante estocado a $-20^{\circ} \mathrm{C}$.

\section{DOSAGEM DE PROTEÍNAS:}

\subsection{Método de Bradford}

As proteinas foram dosadas pelo método de Bradford (1976). A soralbumina bovina (BSA) foi utilızada como padrão de referência. As amostras foram diluídas 1:100, e $10 \mu \mathrm{L}$ destas foram incubadas com $90 \mu \mathrm{L}$ do reagente de Bradford por 10 min a temperatura ambiente. Logo após, a absorbância foi medida no comprimento de onda de $595 \mathrm{~nm}$. A concentração de proteínas for calculada a partir de uma curva padrão de BSA, utilızando o programa Instat.

\subsection{Eagle Eye (Stratagene):}

Este método permite quantificar apenas uma banda de proteína em um gel de polracrilamida. Nossas amostras foram submetidas ao SDS-PAGE 12\% juntamente com quantidades crescentes de soroalbumina bovina (BSA) $(0,05$ a $1,6 \mu \mathrm{g}$ de proteina por fileira). Após a corrida as bandas foram coradas com Comassie blue. O aparelho determinou um valor de intensidade para cada banda de BSA, construiu uma curva padrão de concentração de BSA por intensidade da coloração das bandas. A quantidade de proteína presente nas amostras foi automaticamente calculada frente a essa curva e os valores apresentados em $\mu \mathrm{g}$. 


\subsection{Espectrofotometria:}

As proteínas de fusão foram quantificadas mediante leitura da absorbância a $280 \mathrm{~nm}$, segundo recomendado pelo manual do sistema pGEX. Brevemente, as proteínas eluidas da resina foram diluídas ] : 10 em PBS e subseqüentemente submetidas a leitura de $280 \mathrm{~nm}$ em espectrofotômetro. A quantidade de proteína foi calculada a partir do coeficiente de extinção da GST: 1 A280 corresponde a $0,5 \mathrm{mg} / \mathrm{mL}$ de proteína GST.

\section{ELETROFORESE EM GEL DE POLIACRILAMIDA CONTENDO SDS (SDS- PAGE)}

As proteínas foram analisadas por eletroforese em gel de poliacrilamida na presenf̧a de SDS (Laemmli 1970). As amostras correspondentes foram diluídas em um mesmo volume de tampão de amostra contendo 2-mercaptoetanol (2-ME) e fervidas em banho maria por 5 min. O material foi então aplicado em um gel de empacotamento de $5 \%$ e gel de resolução de $12 \%$ de poliacrilamida e submetido a eletroforese com corrente constante de $25 \mathrm{~mA}$. Os géis foram corados com azul de Coomassie R-250, segundo a técnica de Blakesley e Boezi (1977).

\section{WESTERN BLOTTING}

Após o fracionamento por SDS-PAGE, na presença de 2-ME, as proteinas foram transferidas para uma membrana de nitrocelulose (Towbin e col., 1979). Os antigenos presentes na membrana de nitrocelulose foram então submetidos à caracterização imunoenzimática. Após bloqueio com leite em pó desnatado (Molico, Nestlé) $5 \%$ em tampão Tris-Salina (Tris $10 \mathrm{mM}$ e $\mathrm{NaCl} 0,15 \mathrm{M}$, pH 7,5), overnight a $4^{\circ} \mathrm{C}$, as tiras de membrana foram incubadas com os soros dos coelhos (1:1000 em solução bloqueadora), por 3 horas à temperatura ambiente. Em seguida, as membranas foram lavadas com TrisSalina e incubadas por 2 horas com o conjugado anti-lgG de coelho marcado com peroxidase, diluído 4.000 vezes. O excesso de conjugado foi removido com mais um ciclo de lavagens e os antígenos foram então revelados com o substrato cromógeno (4-cloro-1- 
naftol $0,05 \%$ em metanol $15 \%$, em presença de $\mathrm{H}_{2} \mathrm{O}_{2} 0,03 \%$ ), sendo a reação interrompıda com água.

\section{LIGAÇÃO AO COLÁGENO POR TESTE IMUNOENZIMÁTICO:}

Placas de microtitulaçăo de 96 orificios (NUNC.BAMarisorp) foram sensibilizadas durante a noite a $4^{\circ} \mathrm{C}$ em câmara úmida, com $100 \mu \mathrm{L}$ por poço de uma solução contendo $2 \mu \mathrm{g} / \mathrm{mL}$ de colágeno. Após este período, as placas foram lavadas com PBS contendo $0,1 \%$ de Tween 20 (Sigma®i) e, em seguida, bloqueadas por 2 horas a $37^{\circ} \mathrm{C}$ com uma solução de PBS com $1 \%$ de BSA (200 $\mu$ l por poço). Após um novo ciclo de lavagens, as placas foram mantidas a $-20^{\circ} \mathrm{C}$ até o momento do uso.

Nas placas pré-sensibilizadas, foram realizadas diluiçōes seriadas dos fragmentos recombinantes a partir da concentração de $1 \mathrm{mg} / \mathrm{mL}$ (100 $\mathrm{\mu L} /$ orificio). Estas placas foram incubadas por 1 hora a $37^{\circ} \mathrm{C}$ ( $100 \mu \mathrm{L} /$ orificio), em câmara úmida. As placas entào foram lavadas com PBS/Tween e, em seguida, novamente incubadas por I hora a $37^{\circ} \mathrm{C} \mathrm{com}$ anticorpos de coelho anti-jararagina ou anti-GST. Após lavagem foi realizada uma incubação com anticorpo conjugado anti-IgG de coelho marcado com peroxidase (Sigmaß)

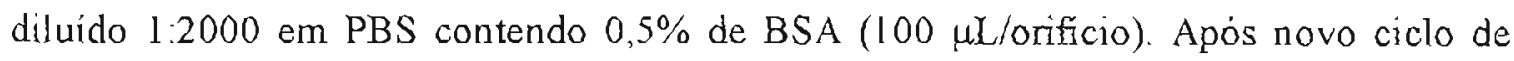
lavagens, a reação foi revelada, adicionando-se $100 \mu \mathrm{L}$ por poço do substrato da enzima ( 1 mģ de OPD - o-Fenilenodiamina/mL em tampão citrato $0,2 \mathrm{M}, \mathrm{pH} 5,0$, mais $0,06 \% \mathrm{H}_{2} \mathrm{O}_{2}$ ). A reação foi intertompida pela adição de $\mathrm{H}_{2} \mathrm{SO}_{4}$ a $30 \%$ (50 $\mu \mathrm{L} / 0$ rificio). A intensidade da reação foi determinada pela leitura da densidade óptica a $492 \mathrm{~nm}$ em Mulstiskan.

\section{ISOLAMENTO DAS PROTEÍNAS EM FUSÃO COM GST:}

As proteínas de fusão foram isoladas seguindo as recomendações do fabricante (Amersham Brosciences). Brevemente, as bactérias ressuspensas em tampão PBS (pH 7,4) foram lisadas por french press. Os extratos bacterianos contendo as proténas de fusão foram subseqüentemente incubados por $30 \mathrm{~min}$ a temperatura ambiente com Glutathione Sepharose 4B ( $1 \mu \mathrm{L}$ por $\mathrm{mL}$ de cultura inicial) sob agitação suave. Em seguida, a resina foi 
centrifugada a $500 \mathrm{~g}$ por 5 min. e o sobrenadante contendo proteínas nâo especificas descartado. Foram realizadas 3 lavagens da resina utilizando PBS, com a finalidade de retirar as proteinas não especificas. Finalmente, as proteínas em fusão com GST foram eluídas com $20 \mathrm{mM}$ de glutationa reduzida pH 8 ( $2 \mu \mathrm{L}$ por $\mathrm{mL}$ de cultura inıcial). Com a finalidade de retirar a glutationa as proteinas de fusão foram dialisadas 2 vezes frente a PBS.

\section{PURIFICAÇÃO EM SISTEMA DE HPLC (HIGH PERFORMANCE LIQUID CHROMATOGRAPHY):}

A proteína de fusão GST/JD49 eluída da coluna foi dialisada frente ao tampão da trombina e subsequientemente submetida a clivagem utilizando I $\mathrm{U}$ de trombina por $100 \mu \mathrm{g}$ de proteina de fusão durante $18 \mathrm{l}$ a temperatura ambiente. A porção JD49 clivada foi obtida em sistema de HPLC en coluna de fase reversa C18 (Vydac, Hesperia, USA) equilibrada em $0,1 \%$ de TFA (Ácido Tri Fluoroacético) e eluída por um gradiente de acetonitrila de 0 a $80 \%$ em um volume de $40 \mathrm{~mL}$ a um fluxo de $2 \mathrm{~mL} / \mathrm{min}$. A cromatrografia foi monitorada por absorbância a $214 \mathrm{~nm}$ e as frações reunidas foram analisadas por SDS-PAGE 18\% quanto a presença de uma banda de baixa massa molecular $(\sim 5 \mathrm{kDa})$ que corresponde a JD49 isolada.

\section{OBTENÇÃO DE PLAQUETAS:}

Sangue humano $(50 \mathrm{~mL})$ obtido de doadores saudáveis foi colhido em solufão de citrato de sódio $3,8 \%(9: 1)$ e centrifugado por 20 min a $125 \mathrm{~g}$ para a obtenção do plasma rico em piaquetas (PRP). O PRP foi retirado e foram adicionados $0,4 \mathrm{~mL}$ de EDT A $2 \%$ para cada $10 \mathrm{~mL}$ de PRP. A solução foi centrifugada a $500 \mathrm{~g}$ por 15 min. Após a centrifugação, o pellet de plaquetas foi vagarosamente ressuspenso em $10 \mathrm{~mL}$ de tampão de lavagem. Esta lavagem foi repetida por mais uma vez e logo após a última centrifugação, o pellet foi ressuspenso em $2 \mathrm{~mL}$ de tyrode's adicionado de glicose para uma concentração final de $1 \%$ $(w / v)$. Após contagem das plaquetas, estas foram diluídas para uma concentração final de 3 $\times 10^{8} / \mathrm{mL}$. 


\section{TESTE DE INIBIÇÃO DA AGREGAÇ̃̃O PLAQUETÁRIA:}

Os efeitos dos fragmentos recombinantes sobre a inibição da agregação plaquetária foram avaliados através da sua incubaçăo com plaquetas por 5 min a $37^{\circ} \mathrm{C}$ antes da adiçăo de 1 $\mu \mathrm{g} / \mathrm{mL}$ de colágeno (Horm-Chemie). A extensão da inibição da agregação plaquetária foi estimada como a diminuição da porcentagem de transmissão de luz tomando-se como $100 \%$ o valor obtido com as plaquetas desafiadas diretamente com o colágeno, mantidas por 5 min apenas com os diluentes dos fragmentos.

\section{CULTURA CELULAR:}

As linhagens celulares foram cultivadas em $15 \mathrm{~mL}$ de meio DMEM/F $12,10 \% \mathrm{FCS}$ com (A5 e VNRC3) ou sem (Kl) geneticina na concentração de $0,5 \mathrm{mg} / \mathrm{mL}$ a $37^{\circ} \mathrm{C}, 5 \% \mathrm{CO}_{2}$ atè o estabelecimento de uma monocamada de células confluentes. Para os experimentos, as células foram então removidas dos frascos de cultura por adição de $2 \mathrm{~mL}$ de EDT A em PBS (2 $\mathrm{mM}$ ) e lavadas 3 vezes com solução salina $0,15 \mathrm{M}$ por centrifugação a $500 \mathrm{~g}$. A concentração foi ajustada para $4 \times 10^{5}$ células $/ \mathrm{mL}$

\section{ATIVIDADE FOSFATASE ALCALINA:}

A atividade foi calculada utilizando o Alkaline Phosphate Substrate kit da Biorad. Este sistema utiliza o substrato p-Nitrophenylphosphate ( $\mathrm{NNPP}$ ) que ao ser defosforilado pela fosfatase alcalina emite uma coloração amarela que pode ser quantificada a $405 \mathrm{~nm}$ de compnmento de onda. Cinqüenta microlitros dos extratos solúveis de cada amostra foram incubados com $100 \mu \mathrm{L}$ do substrato (pNPP em tampão dietanolamina) a temperatura ambiente até o desenvolvimento de uma cor amarela. A absorbância a $405 \mathrm{~nm}$ foi então medida. Como controle uthlizamos quantidades conhecidas de fosfatase alcalina de $E$. coli. 


\section{8, TESTE DE DOT BLOT:}

Três microlitros, contendo $1 \times 10^{9}$ plaquetas $/ \mathrm{mL}$ ou $4 \times 10^{5}$ células $/ \mathrm{mL}$, foram adicionados a uma membrana de nitrocelulose. As membranas foram bloqueadas com leite em pó desnatado (Molico, Nestlé) 5\% em tampão Tris-Salina por $2 \mathrm{~h}$ a temperatura ambiente. As membranas foram então incubadas com as proteínas recombinantes em fusão com fosfatase alcalina ou GST:

28.1. Com as proteínas em fusão com fosfatase alcalina:

Os extratos periplásmicos correspondentes às proteínas recombinantes (1:15 em soluçâo bloqueadora) foram incubados por $1 \mathrm{~h}$ a $37^{\circ} \mathrm{C}$. Em seguida, a membrana foi lavada com Tris-Salina e as proteínas foram reveladas com o substrato cromógeno NBT/BCIP. A reação foi interrompida pela lavagem extensiva com água destilada.

\subsection{Com os fragmentos em fusão com GST:}

As membranas foram incubadas com os fragmentos recombinantes e os controles por $1 \mathrm{~h}$ a $37^{\circ} \mathrm{C}$; após este periodo as membranas foram lavadas 3 vezes com Tris $/ \mathrm{NaCl}$ e incubadas com o anticorpo anti-GST ou anti-jararagina nativa por $1 \mathrm{~h} \mathrm{a} 37^{\circ} \mathrm{C}$ As membranas foram lavadas novamente e incubadas com anticorpo ant1-IgG de coelho conjugado com peroxidase. Após a última lavagen, os dots foram revelados com alfa-4-cloro-naftol adicionado déágua oxigenada. 


\section{RESULTADOS:}

\section{CARACTERIZAÇ̃̃o DA REGIÃO FUNCIONAL DOS DOMÍNIOS ECD- DISINTEGRINA E RICO-EM-CISTEÍNAS (JARARAGINA-C)}

\section{PLANEJAMENTO:}

Com o objetivo de determinar a região funcional dos dominios ECD-disintegrina e rico-emcisteinas da jararagina, nossa primeira abordagem foi a clonagem e expressão de fragmentos do cDNA da jararagina que codificam diferentes extensões desses domínios, para posterior avaliação da atividade biológica dos polipeptídeos resultantes. Para tanto, selecionamos 8 fragmentos, sendo que 3 correspondem ao domínio ECD-disintegrina, 4 ao domínio rico-emcisteínas e o oitavo fragmento, JDC, corresponde aos dois domínios juntos. $O$ fragmento JDC foi baseado na seqüência protéica da jararagina-C (Moura da Silva e col., 2003) que se estende desde o resíduo 210 até o final da jararagina (421). A escolha dos outros fragmentos foi baseada no padrão de pontes dissulfeto da catrocolastatina-C (Calvete e col., 2000-B) que apresenta $98 \%$ de identidade com a jararagina-C e no alinhamento da jararagina com a eristostatina, menor RGD-disintegrina (49 resíduos); com a bitistatina, maior RGDdisintegrina (83 resíduos); com a catrocolastatina-C e por último com o domínio rico-emcisteinas da atrolisina A. Nossa estratégia foi procurar por regiões funcionais a partir da comparação com a estrutura primária de RGD-disintegrinas ou fragmentos de SVMP da classe P-III com atividade biológica definida.

No alinhamento (fig. 4), podemos observar a alta conservação das cisteinas (vermelho) nas 5 proteinas, sendo que apenas a cisteina 40 da eristostatina e as cisteinas do tripeptídeo ECD (azul) da jararagina-C e catrocolastatina-C não se acham presentes nas outras sequênncias. Cabe lembrar que o tripeptídeo ECD substitui o motivo RGD, presente no loop de interação das disintegrinas clássicas. Por outro lado, o domínio rico-em-cisteínas da atrolisina-A, embora apresente uma menor identidade com a jararagina-C (63\%), conserva todas as cisteinas na mesma posição. A diferença das seqüências da jararagina e catrocolastatina-C, o dominio rico-em-cisteinas da atrolisina-A apresenta dois gaps de 4 resíduos e uma extensão de 9 resíduos na extremidade $C$-terminal. A sequência da bitistatina embora seja uma RGDdisintegrina, apresenta alta homologia com o domínio ECD-disintegrina da jararagina, conservando suas 14 cisteinas No entanto, na região do loop podemos observar maior variação nos resíduos. Por outro lado, a eristostatina apresenta um loop quase idêntico à bitistatina, apresentando mais variação na região $\mathrm{N}$-terminal 


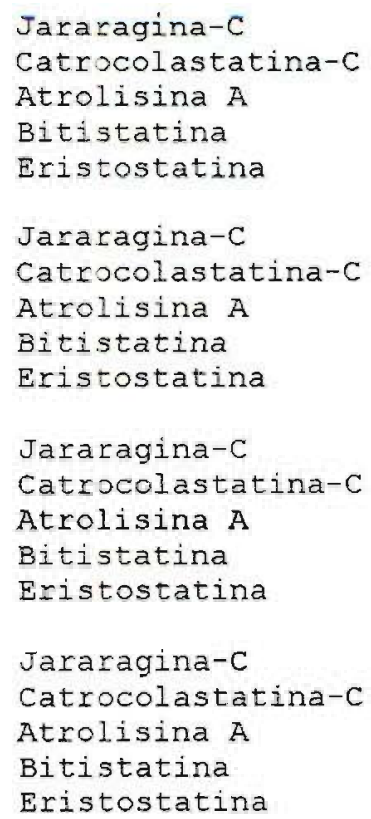

I ISPPVCGNELLEVGEECDCGTPENCQNECCDAATCKLKSGSQCGHGDCCEQCKFSKSGT I ISPPVCGNE LLEVGEE CDCGT PEN CQNECCDAAT CKLKSGSQCGHGDCCEQCKFSKSGT --SPPVCGNEILEQGEDCDCGSPANCQDQCCNAATCKLTPGSQCNHGECCDQCKFKKART -

ECRASMSECDPAEHCTGQSSECPADVFHKNGQP LDNYGYCYNGNC PIMYHQCYALFGAD ECRASMSECDPAEHCTGQS SE C PADVFHKNGQP C LDNYGY YNGNCP IMYHQCYDLFGAD _... VCRIARGDWN-DDYCTGKSSDCPWNH-VCRVARGDWN-DDYCTGKS CDCPRNPWNG------

VYEAEDSCFKDNQKGNYYGYCRKENGKKI PCAPEDVKC GRIYCKDNSPGQNNPC KMFYSN VYEAEDS CFERNQKGNYYGYCRKENGNKIPCAPEDVKC GRLYCKDNSPGQNNPCKMFYSN VTVAPDA CFDINQSGNNSFYCRKENGVNI PCAQEDVKCGRLF CNVN----DFLCRHKYSD VIVAPDAC EDINQSGN

DDEHKGMVLPGTKCADGKVC SNGHCVDVATAY EDEHKGMVLPGTKCADGKVC SNGHCVDVATAY------D----GMVDHGTK ADGKVCKNRQCVDVTTAYKSTSGFSOI D------

Fig 4. Alinhamento da jararagina-C com SVMP do tipo P-III e com RGD-disintegrinas. As sequeencias foram obtidas do banco de dados do NCBI e foram alinhadas utilizando o programa Clustal-W utilizando a matriz gonnet. As cisteínas em vermelho são as conservadas nas 5 seqüências enquanto as cisteinas em azul representam as não conservadas. Os aminoácidos sublinhados em negrito correspondem à região do loop. 
Foram selecionados os seguintes fragmentos:

- JD49, correspondente à porção C-terminal do domínio ECD-disintegrina e análogo à eristostatina. Estes peptídeos compartilham 7 das 8 cisteínas e apresentam uma homologia de $67 \%$. Este fragmento se estende dos resíduos 250-298 da sequeência da jararagina.

- ID89, correspondente ao domínio ECD-disintegrina e análogo à bitistatina. Este fragmento conserva 14 de suas 15 cisteínas com as cisteínas da bitistatina. Segundo o alinhamento as cisteinas estariam envolvidas em 7 pontes dissulfeto com a cisteína livre no motivo ECD. Este fragmento compreende os resíduos 210-298 da seqüência da jararagina.

- JD98 contém o J889 com 9 resíduos a mais na posição C-terminal que incluem a primeira cisteina do domínio rico-em-cisteínas. Esta cisteina formaria assim uma ponte com a cisteína do motivo ECD. Este fragmento se estende dos resíduos 210-307 da sequêencia da jararagina

- JC116, correspondente ao domínio rico-em-cisteinas completo foi baseado no domínio rico-em-cisteinas da atrolisina A (Jia e col., 2000) apresentando uma identidade de 63\% entre ambos. Decidimos excluir os resíduos $\mathrm{N}$-terminal LDNY, primeiro, porque eram os menos conservados no inicio da seqüência e segundo, porque estes resíduos já estavam inclusos no fragmento JD98. Na parte final da seqüência, incluímos apenas os resíduos Cterminal da jararagina que alinham perfeitamente com a atrolisina A. Este fragmento compreende os residuos 304-421.

- JC63, corresponde a um cluster de 3 pontes dissulfeto no centro do dominio rico-emcisteínas e está baseado nas pontes dissulfeto da catrocolastatina-C. Este fragmento se estende dos resíduos 344-405 da sequêência da jararagina.

- JC76, apresenta os resíduos C-terminal do domínio rico-em-cisteínas. Esta extensão contèm duas cisteinas envolvidas em uma ponte. O fragmento compreende os resíduos $344-421$.

- JC103 é similar a JC116, mas não apresenta a extensão C-terminal presente no fragmento JC76, compreendendo os resíduos 304-405 


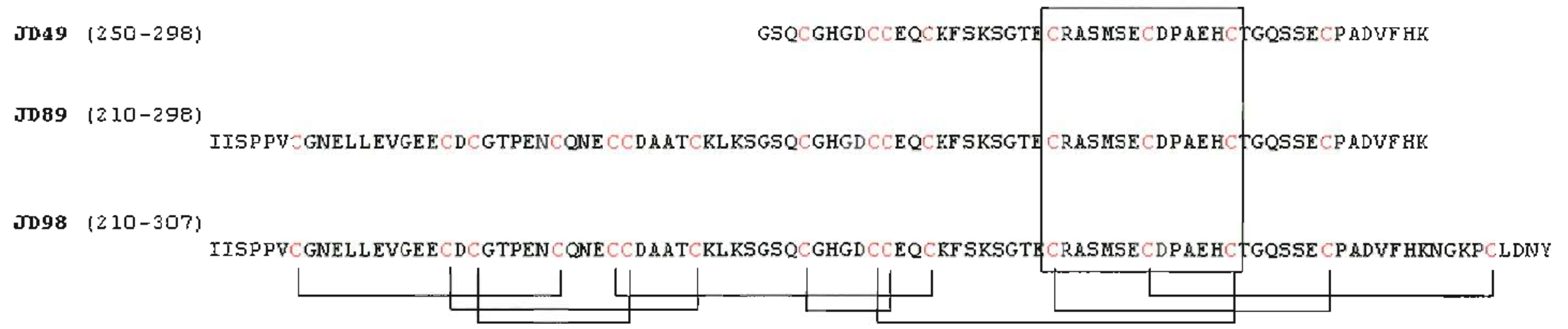

TC63 $(344-405)$

GNYYGYCRKENGNK I P CAPE DUKCGRL Y CKDNSP GONNP CKMF YSNEDEHKGWLPGTK AD

JC76 $(344-421)$

GNYYGXCRKENGNKIPCAPEDVKCGRL YCKDNSPGONNP :. KMF YSNEDEHKGHWLPGTKCADGKVCSNGHCVDATY

$\operatorname{rc103}(304-405)$

GYCYNGNC P IMYHQCYDLPGADVTE BE DSCFERNOKGNYYGY CRKENGNK IP CAFEDVKCGRLYCKDNSPGONNP KHF TSNEDEHKGMVLFTKCAD

TC116 (304-421)

GVC YNGNCP IMYHQC YDL FGADVYEAEDSCFERNQKGNYYGY CRKENGNK IPCAPEDVKC GRL YCKDNSPGONNP KKHF YSNEDEHKGNVLPGTKCADGKVCSNGHCVD A TY L

Fig.5. Fragnertos selecionados. 0 seguirte esquema mosta as sequenias selecionadas com suas respediuas portes

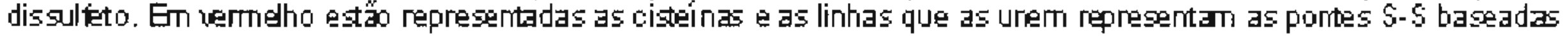
na catrosolastatina C. (Caluete e col., 2000). Os residuos do loop estáo represertados no quadro e as númenos entre parênteses correspondem aos residuos da jararagina madura. 


\section{CLONAGEM:}

\section{- Construção dos oligonucleotídeos:}

Os oligonucleotídeos foram desenhados com ajuda do programa Primer Tool. Levamos em consideração os sítios de clonagem, as bases de apoio para as enzimas de restrição e as 15 primeiras bases do DNA a ser amplificado da seqüência da disintegrina do lado $5^{\prime}$ no oligo sense e do lado $3^{\prime}$ no anti-sense. Adicionalmente, os oligonucleotídeos anti-sense contêm o codon de terminação para a sintese protéica. Os sítios de restrição das endonucleases Bam H I e EcoR I foram adicionados nos primers sense e anti-sense, respectivamente. Estes sitios foram cuidadosamente escolhidos após uma análise de restrição dos fragmentos utilizando o programa WebCutter 2.0 onde verificamos sua ausência nas seqüências. Adicionalmente construímos o oligonucleotídeo de seqüência universal para o pGEX (pGEX5seq) baseado no primer comercializado pela Amersham Biosciences.

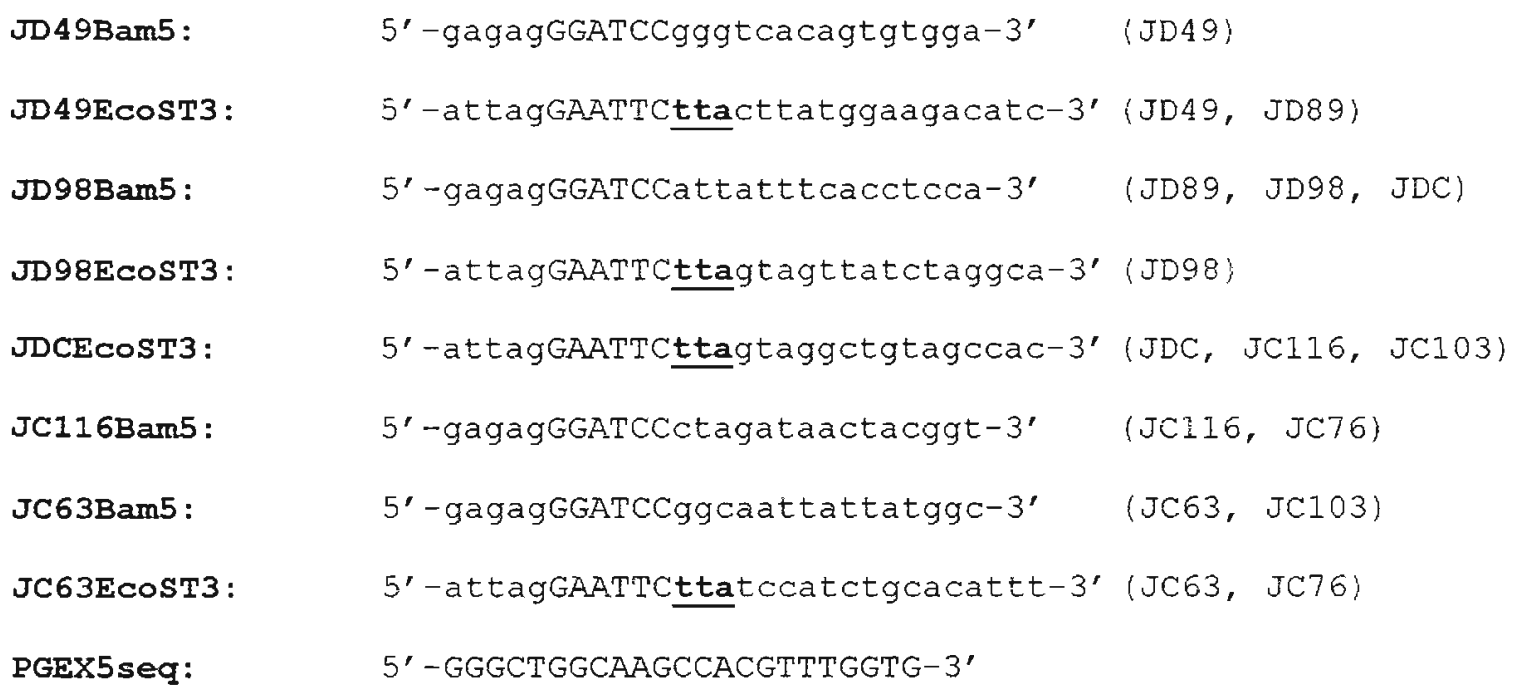

Fig. 6. Oligonucleotideos construídos. Os nucleotídeos em maiúsculas correspondem ao sítio de reconhecimento das endonucleases de restrição. Os nucleotideos em minúsculas à direita do sítio de restrição correspondem as 15 primeiras bases do DNA a ser amplificado da seqüência da disintegrina tanto do lado $5^{\prime}$ como do lado $3^{\prime}$. Os nucleotídeos em minúsculas à esquerda do sítio de restrição correspondem ao lugar de apoio para as endonucleases. Os 3 nucleotídeos em negrito e sublinhados correspondem ao codon de terminação. Entre parênteses está o fragmento ou fragmentos resultantes da amplificação com esse oligonucleotídeo. 
- Amplificação do inserto por PCR e clonagem:

Todos os fragmentos foram amplificados por PCR a partir do clone BjD4 contendo o cDNA da jararagina clonado em $\lambda Z a p I I$ (Paine e col., 1992) utilizando os oligonucleotídeos acima descritos segundo o caso. Foram feitas 4 reações de $50 \mu \mathrm{L}$. Uma reação sem o cDNA da jararagina foi usada como controle negativo. A amplificação dos produtos foi confirmada por gel de agarose $1 \%$ e a concentração do DNA foi calculada obtendo-se entre 160 e $220 \mathrm{ng} / \mathrm{\mu L}$. Os produtos de PCR foram digeridos com BamH I e EcoR I e subseqüentemente ligados no vetor pGEX-4T-1 previamente digerido com as mesmas enzimas. Como controle negativo fizemos uma ligação só com o produto de PCR e outra só com o vetor tratado com as endonucleases. Estes produtos de ligação foram utilizados para transformar $E$. coli DH5 $\alpha$ que posteriormente foram semeadas em placas de L-Agar contendo ampicilina. Na placa correspondente apenas ao produto de PCR não pudemos observar o crescimento de colônias No entanto, na placa correspondente à transformação com o vetor cortado cresceram algumas colonnias, provavelmente procedentes de digestões parciais do vetor religadas. Nas placas semeadas com as bactérias transformadas com os produtos de ligação houve crescimento de um número bem maior de colônias. Como controle de bactéria crescemos E. colt DH5a não transformada em placas com e sem ampicilina. Na primeira não houve crescimento, demonstrando-se a susceptibilidade da bactéria à ampicilina e a segunda apresentou um crescimento uniforme e espalhado mostrando a viabilidade da mesma.

\section{- Triagem:}

JD49

Dez colônias foram analisadas por PCR direto utilizando os primers de amplificação JD49Bam5 e JD49EcoST3. No gel abaixo (figura 7) podemos verificar a amplificação de uma única banda de $150 \mathrm{pb}$ a partir dos 10 clones demonstrando o êxito da clonagem (colunas l10). Como controle corremos no último canal o produto de PCR de um clone contendo um inserto não relacionado onde podemos observar a ausência de amplificação. O clone 3 foi sequienciado utilizando o primer pGEX5seq. A seqüência deste clone correspondeu perfeitamente com a seqüência esperada demonstrando a inserção correta do cDNA no sítio de clonagem selecionado. Este clone recebeu o nome de $\mathrm{pKD} 31$. 


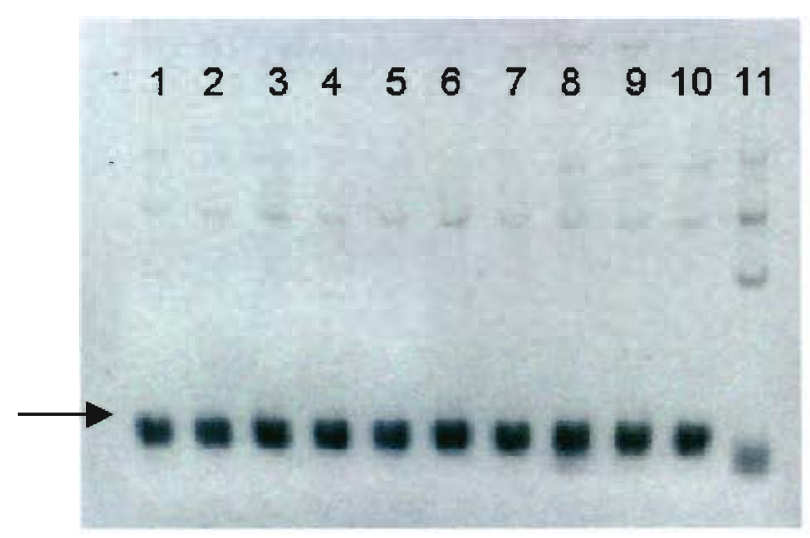

Fig 7. Triagem das colônias por PCR. As colônias foram triadas por PCR utilizando os primers de clonagem JD49Bam5 e JD49EcoST3. O produto de PCR foi analisado em gel de agarose $1 \%$. As fileiras $1-10$ correspondem aos 10 clones analisados. Como controle negativo realizamos uma reação a partir de um clone com inserto não relacionado (11).

\section{JD89 e JD98}

Os clones foram analisados por PCR utilizando-se o primer de seqüência pGEX5seq e o primer interno antisense, respectivo para cada fragmento. Como mostra a figura 8 , que corresponde à análise de 10 clones para JD89, pode-se verificar que somente o clone 4, sinalizado com a seta branca, apresentou a banda esperada de $300 \mathrm{pb}$. Entretanto, a clonagem do fragmento JD98 (parte superior), apresentou-se mais eficaz com 50\% dos clones positivos $(3,4,6,7$ e 9). O clone 4 do JD89 e o 3 de JD98 foram seqüenciados demonstrando-se a correta clonagem dos fragmentos.

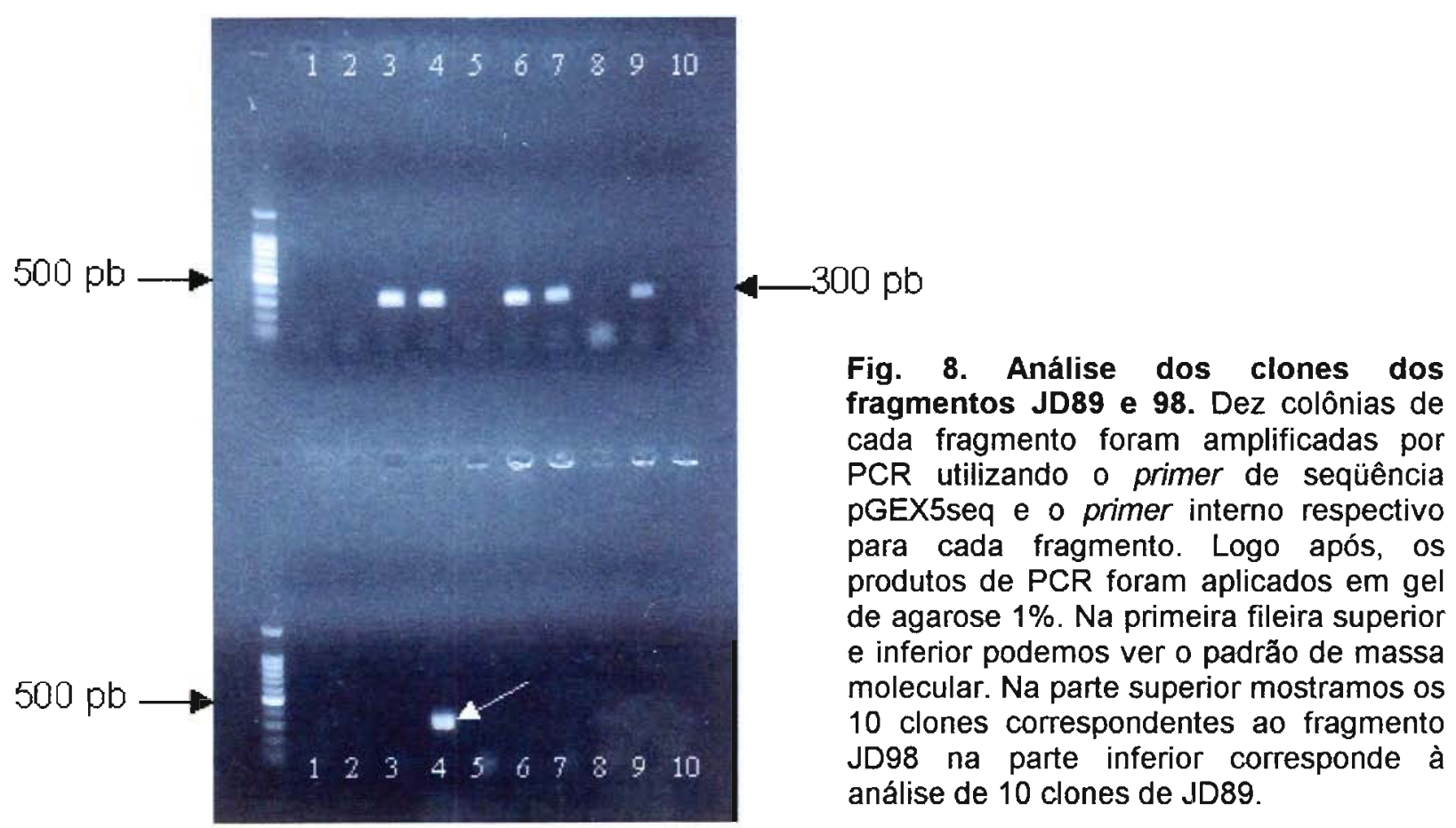


JDC

A triagem foi feita por PCR a partir de 20 clones conseguindo-se $85 \%$ de clones positivos. Vinte clones foram amplificados por PCR utilizando o primer de sequiência pGEX5seq e o primer JDCEcoST3. A figura 9 mostra a banda de $700 \mathrm{pb}$ correspondente ao produto esperado. $\mathrm{Na}$ linha central de corrida estão as bandas correspondentes ao padrão de migração. O clone selecionado pela intensidade da banda foi o 17, o qual foi seqüenciado mostrando sua correta inserção no quadro de leitura do vetor.

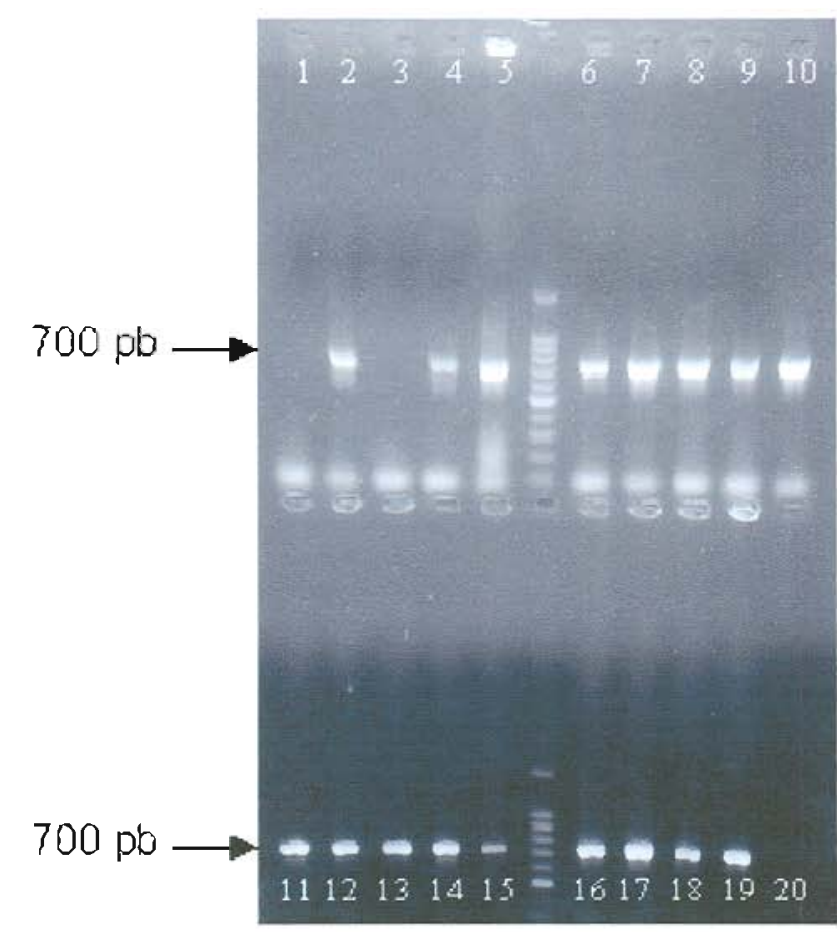

Fig. 9. Análise dos clones correspondentes ao fragmento JDC. Vinte clones foram ampliados por PCR utilizando o primer de sequeencia pGEX5seq e 0 primer JDCECOST3. Os produtos foram fracionados em gel de agarose $1 \%$. Os clones analisados estào denotados com números. $\mathrm{Na}$ parte central estão as bandas correspondentes ao padrão de PM.

\section{JC63, JC76, JC103 e JC116}

Os clones foram analisados por PCR utilizando-se o primer de seqüência pGEX5seq e o primer interno anti-sense, respectivo para cada fragmento. A figura 10 mostra a análise de 5 clones para cada um dos 4 fragmentos. A clonagem do fragmento JC116 resultou em 4 clones positivos nos quais se pode verificar a presença da banda de $350 \mathrm{pb}$; JC103 apresentou 3 clones positivos representados pelas bandas de $315 \mathrm{pb}$; JC76 também apresentou 3 clones positivos que revelaram a banda de $228 \mathrm{pb}$; e por último, o fragmento JC63 representado pela banda de $190 \mathrm{pb}$, apresentou 2 clones positivos. Os clones foram selecionados com relação a intensidade de banda, sendo que para JC116, JC103, JC76 e JC63 escolhemos os clones 5, 2, 5 e 3 , respectivamente. Estes clones foram subseqüentemente seqüenciados confurmando-se a correta amplificação e inserção no vetor. 


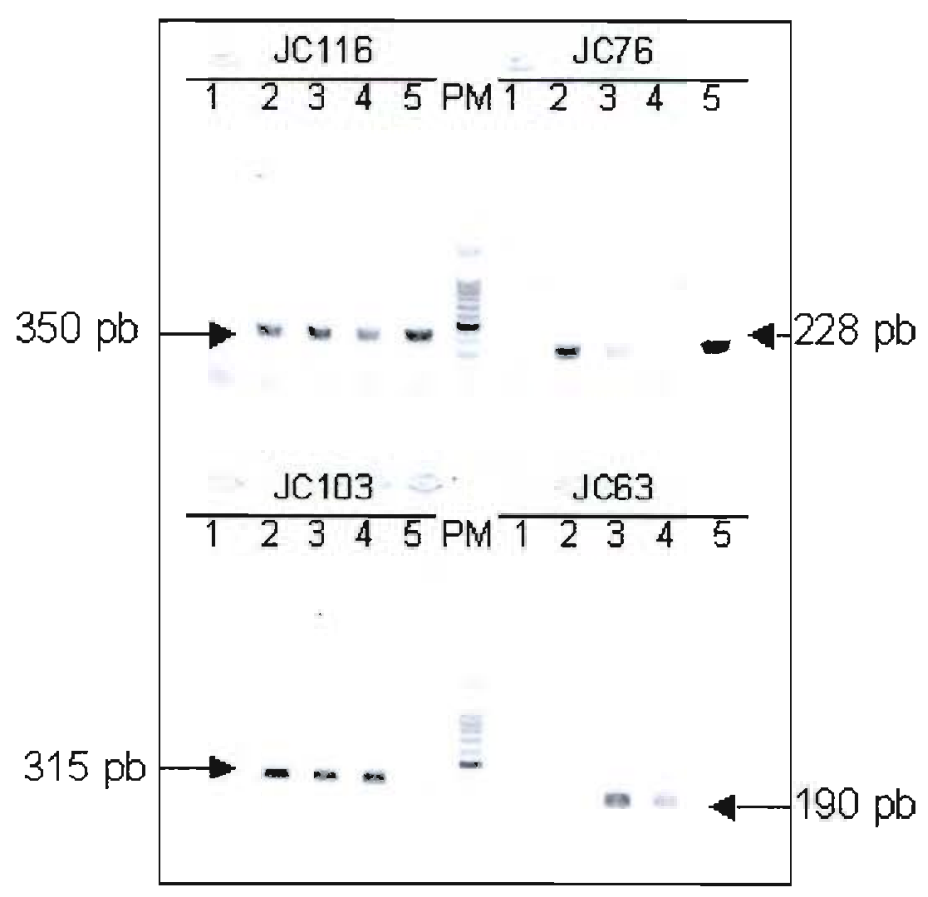

Fig. 10. Análise da clonagem dos fragmentos do domínio rico-em-cisteínas. Cinco clones correspondentes a cada um dos fragmentos foram amplificados por PCR utilizando o primer de seqüência pGEX5seq e o primer interno antisense respectivo para cada fragmento. Na parte central do gel se encontra o padrão de massa molecular. Na parte superior esquerda estão presentes os clones correspondentes a JC116; na direita destes se encontram os clones de JC76. Na parte inferior esquerda e direita, se encontram os clones para JC103 e JC63, respectivamente.

\section{EXPRESSÃO:}

Os clones foram utilizados para transformar a linhagem de E. coli BL21. A expressão foi padronizada com respeito a concentração de IPTG, tempo e temperatura de indução resultando em valores de $100 \mu \mathrm{M}$ de IPTG por $4 \mathrm{~h}$ a $37^{\circ} \mathrm{C}$ (dados não mostrados). Após indução, o material foi analisado por SDS-PAGE $12 \%$. Como podemos ver na figura 11 , as proteínas correspondentes a GST (2), GST/JDC (3), GST/JD49 (4), GST/JD89 (5), GST/JD98 (6), GST/JC63 (7), GST/JC76 (8), GST/JC103 (9) e GST/JC116 (10) foram expressas com sucesso na forma solúvel. Na primeira fileira podemos ver o padrão de massa molecular. Como controle de expressão analisamos o produto do pGEX selvagem onde podemos ver a banda de $27 \mathrm{kDa}$ correspondente a GST (fileira 2). Nas fileiras 3 a 10 podemos ver bandas maiores correspondentes as proteínas de fusão GST/JDC (50 kDa), GST/JD49 (32 kDa), GST/JD89 (36 kDa), GST/JD98 (37 kDa), GST/JC63 (34), GST/JC76 (35 kDa), GST/JC103 $(38 \mathrm{kDa})$ e GST/JC116 (40 kDa). 


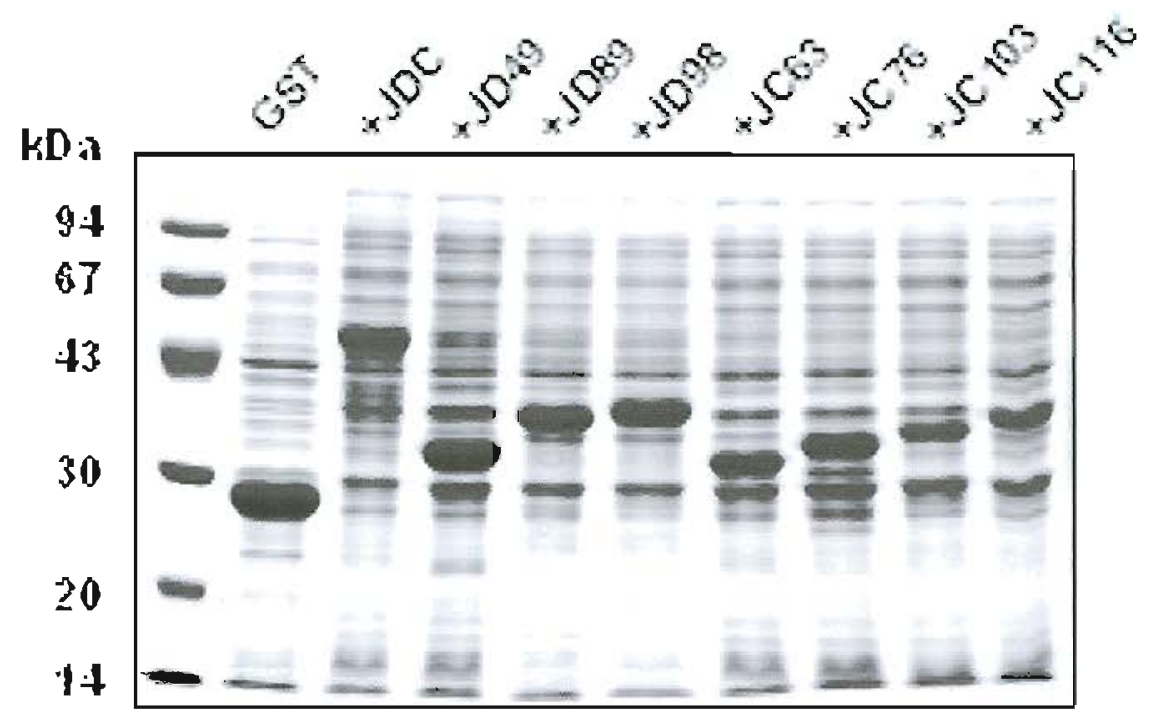

Fig. 11. Análise da expressão por SDS-PAGE. Colônias em fase logaritmica de crescimento foram induzidas por $4 \mathrm{~h}$ com IPTG. Após centrifugação o pellet bacteriano foi ressuspenso em 1/10 de volume e logo após as bactérias foram lisadas por french press. O extrato solùvel foi analisado por SDS-PAGE 12\%: A primeira fileira corresponde ao padrão de massa molecular. Como controle de expressão analisamos o produto do pGEX selvagem (2). As fileiras 3 a 10 correspondem a amostras das proteínas de fusão GST/JDC, GST/JD49, GST/JD89, GST/JD98, GST/JC63, GST/JC76, GST/JC 103 e GST/JC116, respectivamente.

\section{PURIFICACÃO DOS FRAGMENTOS COM GLUTATIONA SEPHAROSE.}

As proteínas de fusão foram isoladas por afinidade a glutationa Sepharose $4 \mathrm{~B}$ como descrito em material e métodos. Após eluição das proteínas, a purificação foi verificada por SDSPAGE 12\%. Na figura 12, podemos observar pela intensidade das bandas e pela quantificação protéica que as proteínas de fusão não foram igualmente purificadas. GST/JD49 (4) apresentou melhor concentração com $2,1 \mathrm{mg} / \mathrm{mL}$. As bandas correspondentes a GST/JD89 (5), GST/JD98 (6) e GST/JC63 (7) foram preferencialmente purificadas e apresentaram concentração similar com 1,35 mg/mL, $1,15 \mathrm{mg} / \mathrm{mL}$ e $1,2 \mathrm{mg} / \mathrm{mL}$, respectivamente. GST/JDC (3), apresentou uma concentração de $0,7 \mathrm{mg} / \mathrm{mL}$, no entanto, no gel podemos ver várias bandas menores que devem cortesponder a produtos truncados de expressão. Proteinas truncadas também podem ser observadas conjuntamente com a banda do GST/JC76 (8) que apresentou concentração de $0,9 \mathrm{mg} / \mathrm{mL}$. Já os fragmentos GST/JC103 (9) e GST/JC116 (10) apresentaram baixa concentração com $0,3 \mathrm{mg} / \mathrm{mL}$ e $0,5 \mathrm{mg} / \mathrm{mL}$, respectivamente. Junto com esses fragmentos, podemos ver bandas correspondentes a proteínas truncadas também. 


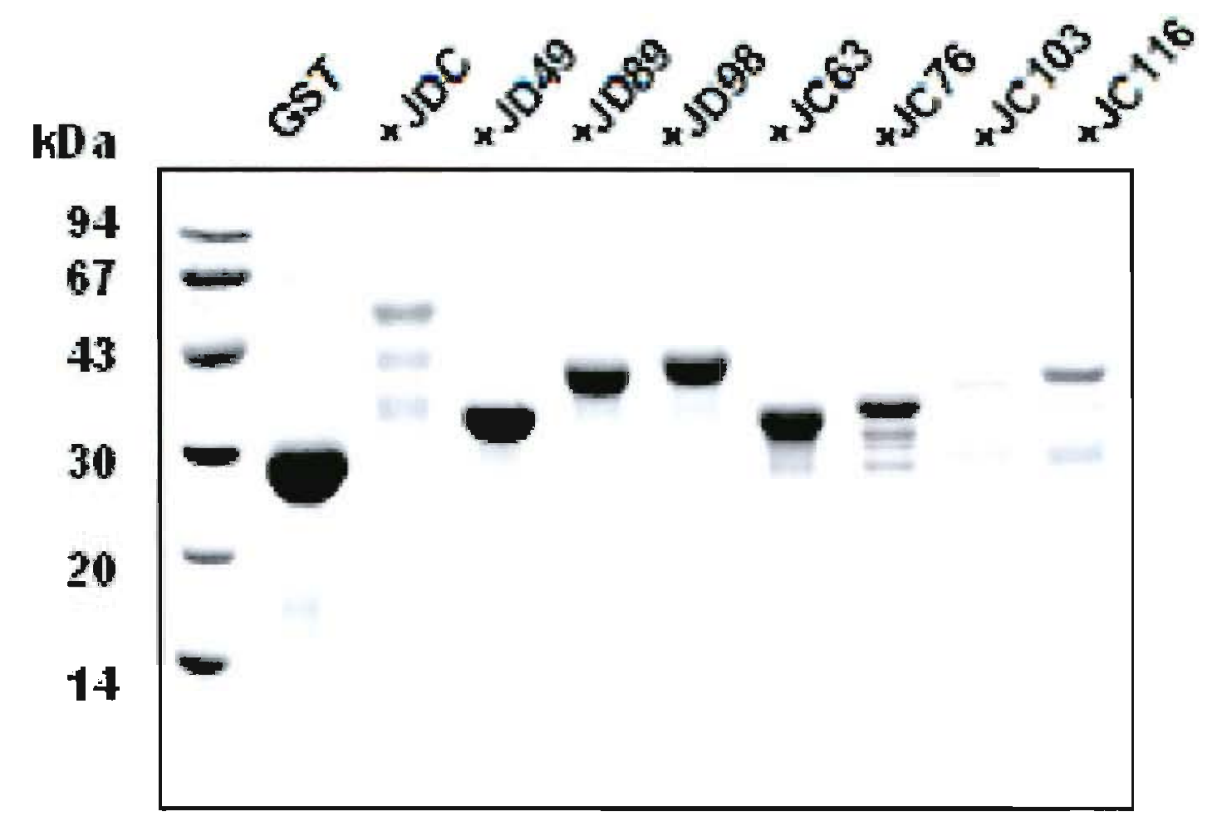

Fig. 12. Análise da purificação por SDS-PAGE. Os extratos bacterianos contendo as proteinas de fusão foram purificados com Glutationa Sepharose 4B e as proteinas eluídas foram analisadas por SDS-PAGE $12 \%$. Na primeira fileira podemos ver o padräo de massa molecular. Como controle purificamos o produto do pGEX selvagem (2). Nas fileiras 3 a 10 estão presentes os produtos de purificação das proteinas de fusão GST/JDC, GST/JD49, GST/JD89, GST/JD98, GST/JC63, GST/JC76, GST/JC103 e GST/JC116, respectivamente.

\section{ATIVIDADE BIOLÓGICA:}

A atividade biológica de todos os fragmentos foi avaliada pela inibição da agregação plaquetária, ensaios de ligação a plaquetas e ao colágeno e pela reatividade frente ao MAJar3, anticorpo monoclonal neutralizante da atividade hemorrágica e afinidade pelo colágeno presentes na jararagina nativa (Tanjoni e col., 2003).

\section{- Inibição da agregação plaquetária dependente de colágeno.}

Os resultados de agregação plaquetária estão mostrados na figura 13. Em A, podemos ver o perfil normal de agregação para os 2 canais após adição de $1 \mu \mathrm{g} / \mathrm{mL}$ de colágeno; em $\mathrm{B}$, a inibição total por parte da jararagina nativa na concentração de $100 \mu \mathrm{g} / \mathrm{mL}$ (controle positivo em preto) enquanto a GST (controle negativo em azul) na concentração de $400 \mu \mathrm{g} / \mathrm{mL}$ foi incapaz de inibir esta atividade. Os resultados de inibição com nossos fragmentos na concentração de $400 \mu \mathrm{g} / \mathrm{mL}$ (C-F) mostraram-se negativos. Nenhum fragmento foi capaz de inibir a agregação plaquetária dependente de colágeno nas condições do teste. Testes com concentrações menores deram o mesmo resultado (dados não mostrados). 

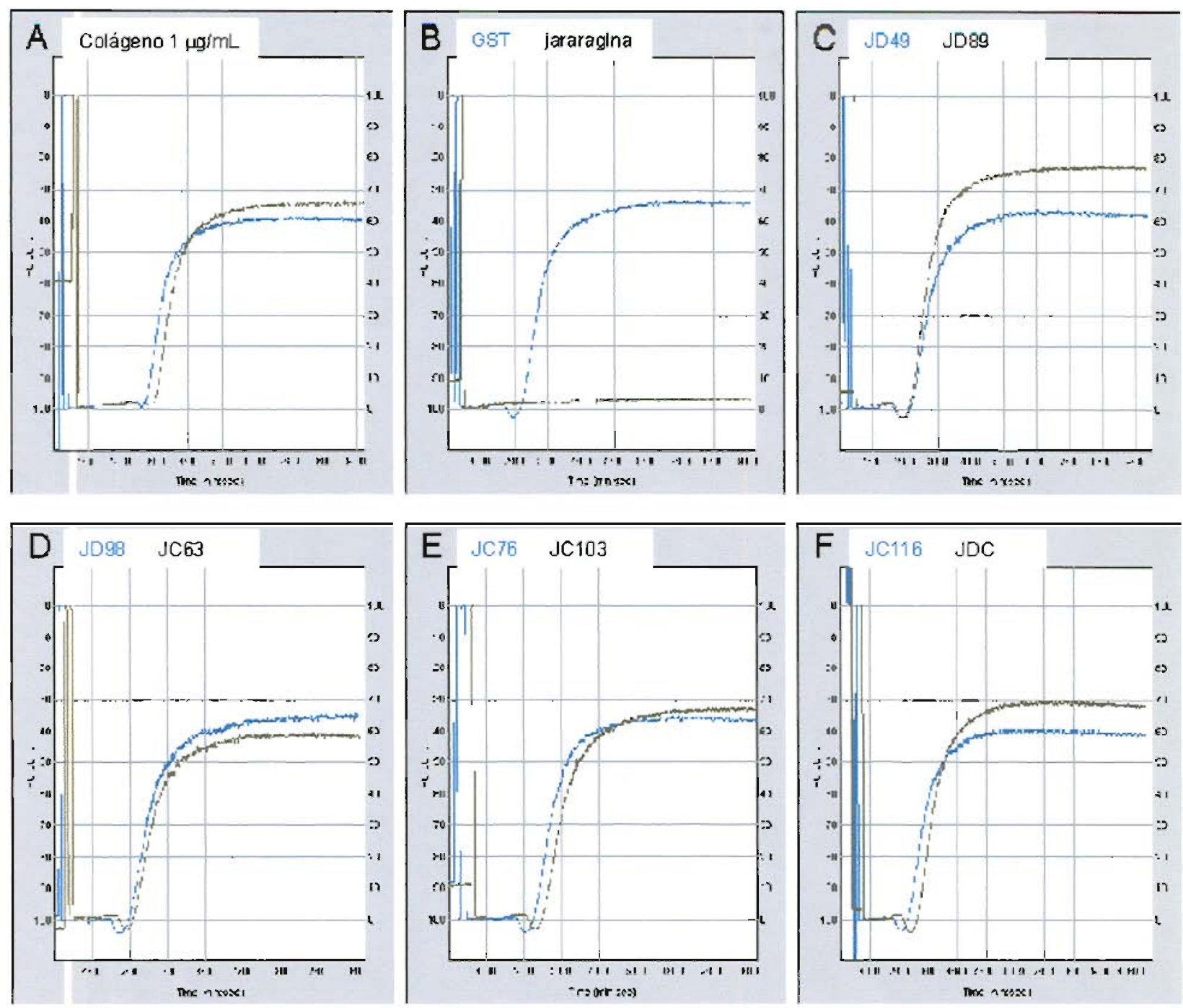

Fig. 13. Teste de íniblção da agregação plaquetária. Os fragmentos recombinantes $(200 \mu \mathrm{g})$ foram incubados com plaquetas lavadas por $5 \mathrm{~min}$ a $37^{\circ} \mathrm{C}$ antes da adição de $1 \mu \mathrm{g} / \mathrm{mL}$ de colágeno. A extensão da inibição da agregação plaquetảria foi estimada como a diminuição da porcentagem de transmissāo de luz tomando-se como $100 \%$ o valor obtido com as plaquetas desafiadas diretamente com o colágeno (A). Como controle negativo utılizamos $400 \mu \mathrm{g} / \mathrm{mL}$ de GST (B em azul) e como controle positivo $100 \mu \mathrm{g} / \mathrm{mL}$ de jararagina (B em preto). Os testes com $400 \mu \mathrm{g} / \mathrm{mL}$ dos fragmentos estão mostrados nas figuras $\mathrm{C}$ a $\mathrm{F}$. 
- Avaliação dos fragmentos quanto à sua ligação às plaquetas por dot blot.

Como alternativa ao teste de agregação plaquetária, decidimos avaliar a ligação direta dos fragmentos à plaqueta por dot blot. A figura 14 mostra que enquanto a jararagina se liga às plaquetas e ao colágeno; os fragmentos não conseguiram ligar-se, mostrando que não interagem com estas moléculas. Como controle positivo incubamos dots de proteínas recombinantes com os soros anti-jararagina e anti-GST onde podemos ver sua reatividade.

Anti-GST

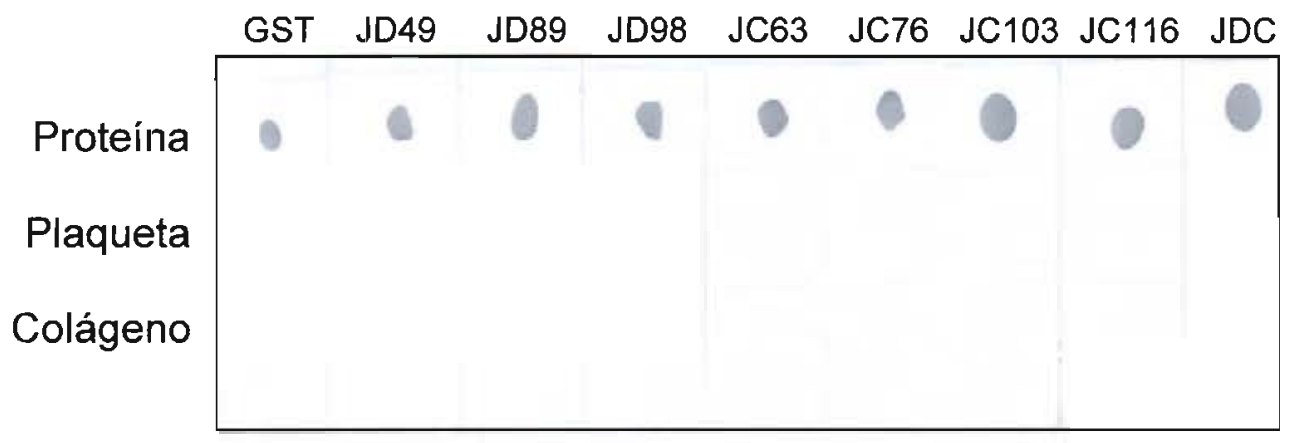

Anti-jararagina

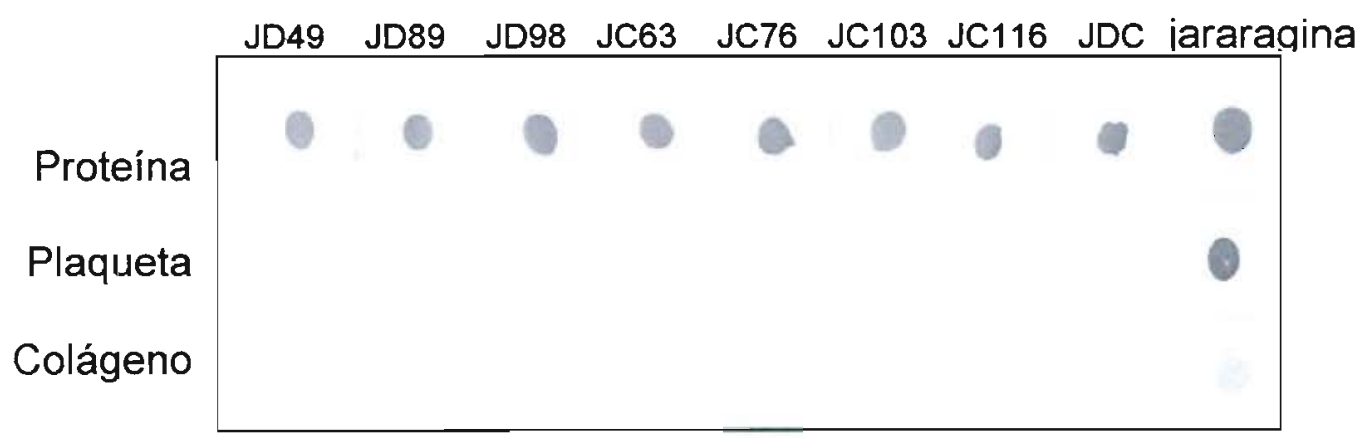

Fig. 14. Teste de adesão por dot blot. Membranas de nitrocelulose contendo $1 \times 109$ plaquetas $/ \mathrm{mL}$ ou $1 \mathrm{mg} / \mathrm{mL}$ de colágeno foram incubadas com os fragmentos recombinantes por $1 \mathrm{~h}$ a $37^{\circ} \mathrm{C}$; após este periodo as membranas foram lavadas 3 vezes com Tris/ $\mathrm{NaCl}$ e incubadas com o anticorpo antiGST ou anti-jararagina nativa por $1 \mathrm{~h}$ a $37^{\circ} \mathrm{C}$. As membranas foram lavadas novamente e incubadas com anticorpo anti-IgG de coelho conjugado com peroxidase. Após a última lavagem, os dots foram revelados com alfa-4-cloro-naftol adicionado de água oxigenada. 
- Avaliação dos fragmentos quanto à sua ligação ao colágeno por ensaio imunoenzimático.

A ligação dos fragmentos ao colágeno foi também verificada utilizando placas de ELISA, através de um ensaio quantitativo. Neste teste verificamos que a jararagina tem aita afinidade pelo colágeno ligando-se em concentrações de $5 \mathrm{nM}$ (não mostrados), porém os fragmentos não conseguiram ligar-se. Na concentração de $0,5 \mathrm{mg} / \mathrm{mL}$, a extensão da ligação foi comparável à do GST utilizado como controle (figura 16A). No entanto, decidimos verificar se os fragmentos poderiam inibir a ligação da jararagina ao colágeno. Na figura 16B mostramos um ensaio de competição utilizando $10 \mathrm{ng}$ de jararagina e $0,5 \mathrm{mg}$ dos fragmentos por pocinho $(100 \mu \mathrm{L})$. Podemos ver uma baixa inibição de $14 \%$ no caso de JDC, mas que desconsideramos devido ao fato desse valor não ser estatisticamente significante. Deste modo confirmamos a baixa afinidade dos fragmentos para interagir com esta molécula.

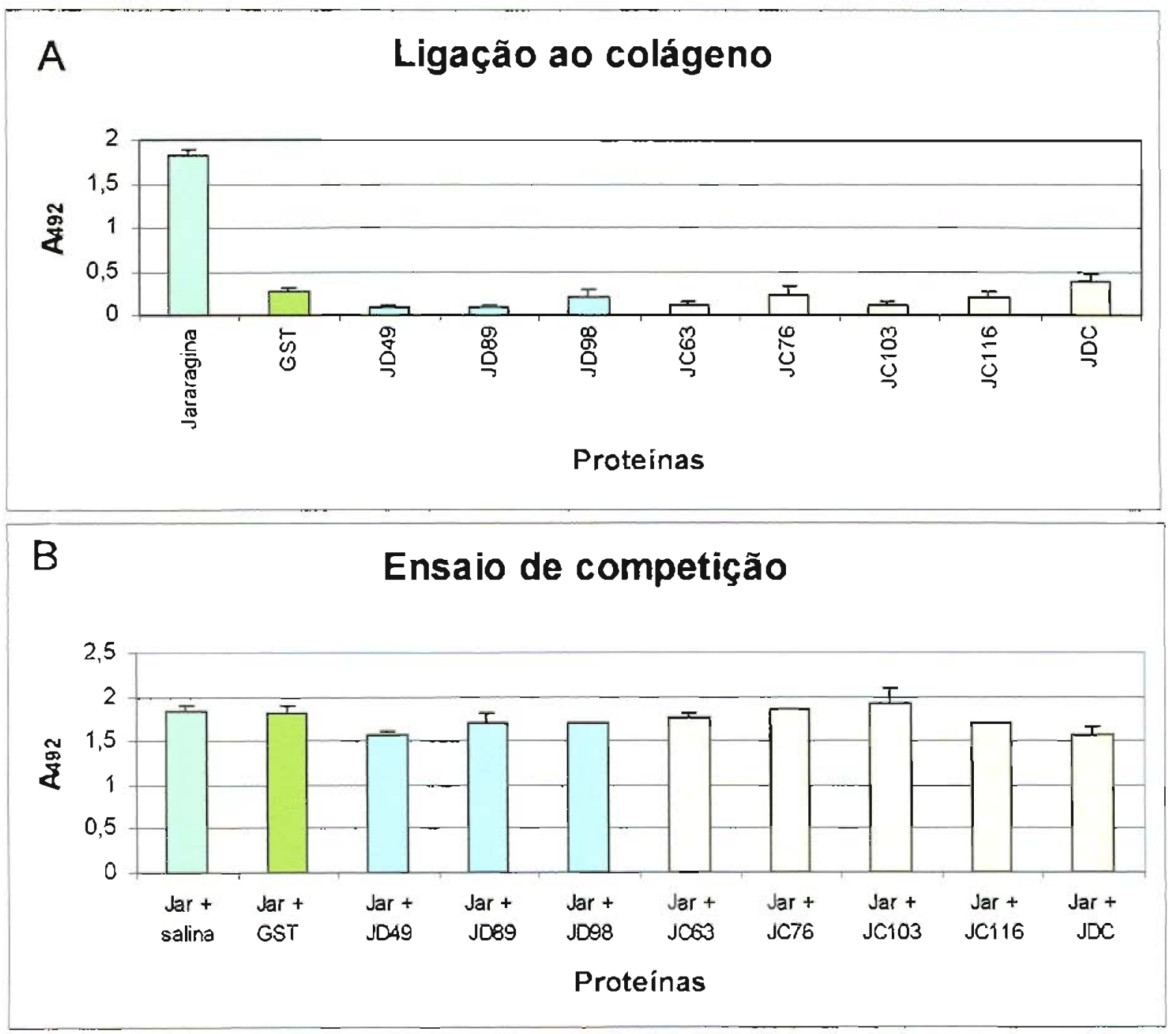


Fig. 15. Teste de ligação ao colágeno por ELISA. Placas de microtitulação de 96 poços foram sensibilizadas por 12 a 18 horas, a $4^{\circ} \mathrm{C}$ em câmara úmida, com $100 \mu \mathrm{L}$ por poço de uma solução contendo $2 \mu \mathrm{g} / \mathrm{mL}$ de colágeno. Após este período, as placas foram lavadas com PBS contendo $0,1 \%$ de Tween 20 (Sigma) e, em seguida, bloqueadas por 2 horas a $37^{\circ} \mathrm{C}$ com uma solução de PBS com $1 \%$ de BSA (200 $\mu \mathrm{L}$ por poço). Após um novo ciclo de lavagens, as placas foram mantidas a $-20^{\circ} \mathrm{C}$ até o momento do uso. As placas foram incubadas por $1 \mathrm{~h}$ a $37 \mathrm{C}$ com $0,5 \mathrm{mg}$ dos fragmentos recombinantes em um ensaio de ligação $(A)$ ou com $0,5 \mathrm{mg}$ dos fragmentos recombinantes mais 10 ng de jararagina em um ensaio de competição (B), quantidades estas contidas em $100 \mathrm{~mL}$ de reação. Como controle positivo utilizamos jararagina e como controle negativo GST. As reações foram então incubados com soro anti-GST (A) ou anti-jararagina (B), as placas lavadas e subseqüentemente incubadas com anticorpo conjugado anti-lgG de coelho. Após lavagens as placas foram reveladas $\mathrm{e}$ lidas como indicado na parte experimental.

\section{- Reatividade dos fragmentos frente a anticorpos neutralizantes:}

A caracterização da região biologicamente ativa da jararagina foi então analisada de forma indireta através da localização de epítopos reconhecidos por anticorpos neutralizantes. Os fragmentos recombinantes foram então utilizados como antígenos em testes de dot blot com anticorpos policlonais ou com o anticorpo monoclonal MAJar3, que inibe a ligação da jararagina ao colágeno e neutraliza a atividade hemorrágica desta. Quando testado com nossos fragmentos (figura 16), MAJar3 reagiu com JD49, JD89 e JD98, não apresentando reatividade com os fragmentos correspondentes ao domínio rico em cisteínas. Os três fragmentos reconhecidos formam parte do domínio ECD-disintegrina, sendo que JD49 corresponde à porção C-terminal, análoga às menores RGD-disintegrinas. Este resultado sugere a importância da porção C-terminal do domínio disintegrina (JD49) como moduladora das atividades biológicas da jararagina.

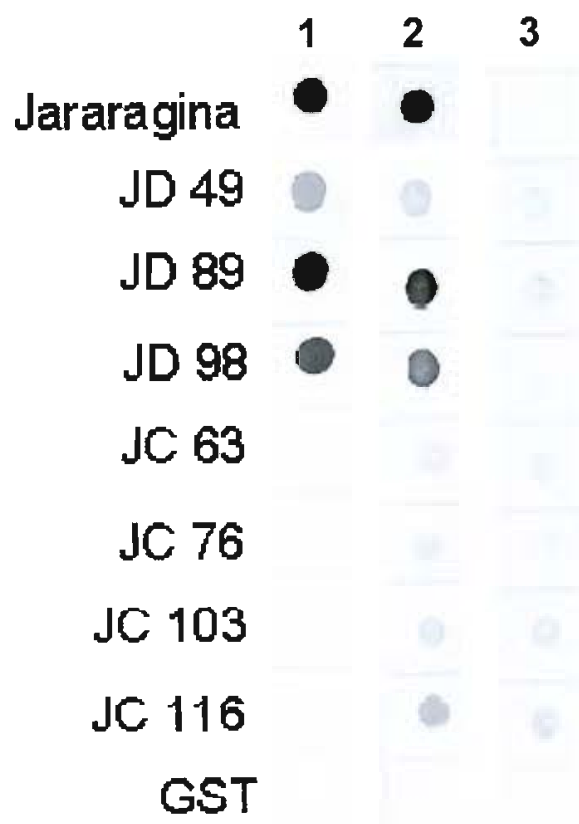

Fig. 16. Reatividade dos fragmentos frente a anticorpos neutralizantes. A reatividade dos fragmentos foi testada foi testada frente ao anticorpo monoclonal MAJar3 (coluna 1) e ao anticorpo policlonal murino anti-jararagina (coluna 2). Como controle negativo utilizamos soro normal de camundongo (coluna 3 ). No lado esquerdo da figura podemos verificar os fragmentos recombinantes e a jararagina e a GST utilizadas como controle. 


\section{CARACTERIZAĊ̃O DO FRAGMENTO JD49:}

Uma vez demonstrada a reatividade do fragmento JD49 com o anticorpo neutralizante MAJar3, passamos a melhor estudar suas propriedades. Esse fragmento apresenta uma massa molecular teórica de 5199,6 e um ponto isoelétrico (pI) de 5,05. Sua estrutura 3-D foi determinada por modelagem. Este fragmento foi também separado da GST por clivagem com trombina e posteriormente purificado por HPLC e analisado quanto a atividade biológica.

\section{- Modelagem:}

A sequência do fragmento JD49 foi analisada pela Dra. Dulce Ferreira, do Instituto de Física de São Carlos da Universidade de São Paulo para a determinação de sua estrutura terciária por modelagem, utilizando a echistatina como molde. O modelo de JD49 apresenta um enovelamento muito semelhante ao da echistatina apesar da baixa identidade entre as duas seqüências $(34,78 \%)$. Na figura 17 podemos ver o modelo de JD49 com a estrutura secundaria e o loop contendo a seqüência ECD. No modelo podemos observar que JD49 é composta por duas fitas- $\beta$ (em laranja) e um loop com a seqüência ECD no seu ápice. Na sobreposição do modelo de JD49 com a estrutura da echistatina (figura 19) podemos observar que as seqüencias RGD e ECD não estão exatamente sobrepostas e os únicos resíduos que ocupam posições equivalentes são o ácido aspártico do RGD e o ácido glutâmico do ECD. Com respeito às pontes dissulfeto o modelo identifica 3 pontes formadas entre a Cys4-Cys 13 , Cys9-Cys35 e Cys22-Cys42, sendo que as Cys10 e Cys29 permaneceriam livres. A análise de qualidade do modelo mostra que $48,8 \%$ dos resíduos se encontram. em uma região favorável, $36,6 \%$ se encontram em regiões adicionalmente permitidas e só um resíduo, a serina 27 , está localizado em uma regiăo desfavorável. Este residuo encontra-se no loop que contém a seqüência ECD e provavelmente apresenta certa flexibilidade o que pode justificar os valores desfavoráveis apresentados. Em resumo o modelo obtido sugere uma estrutura estável, com a sequência ECD exposta no loop e com a cisteina livre. 


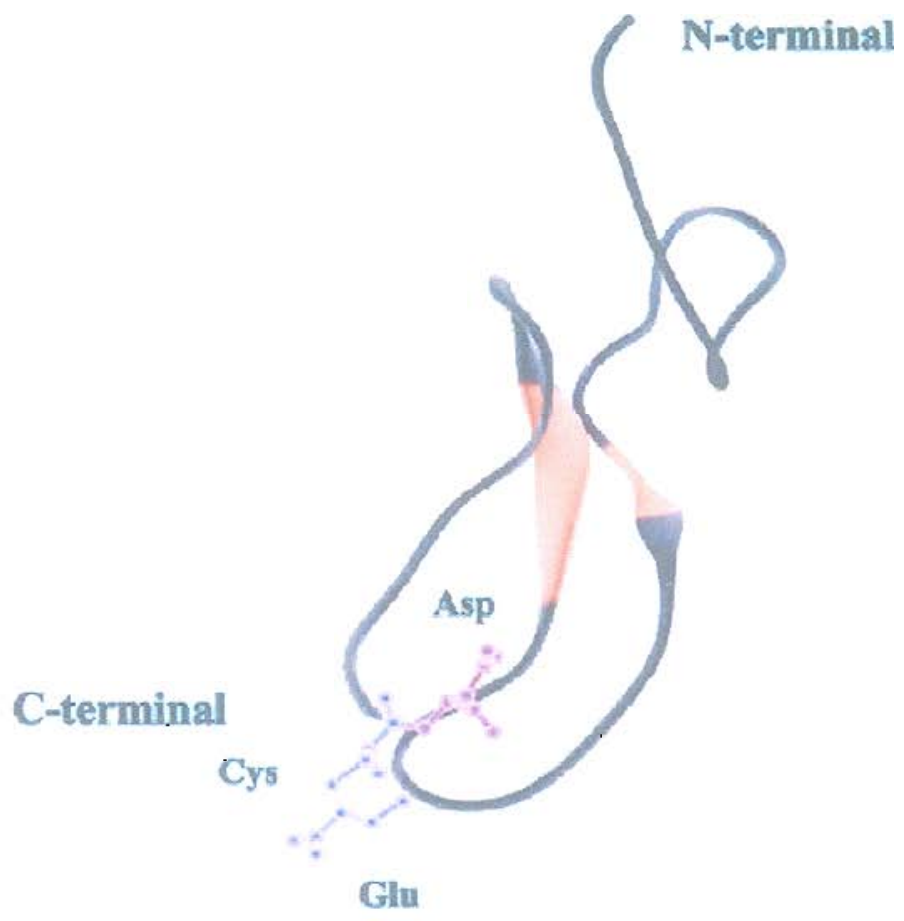

Fig. 17. Modelagem molecular de JD49. Esta sequiência foi modelada utilizando a estrutura terciária da echistatina oblida por RMN como molde.

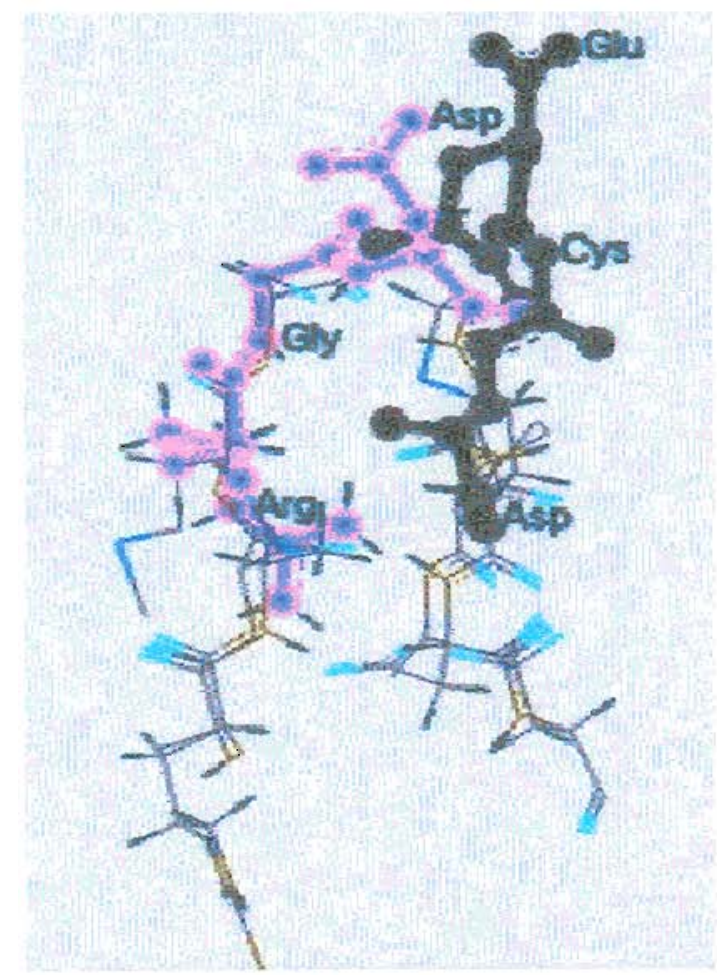

Fig 19. Sobreposição das estruturas dos loops da echistatina e de JD49. O modelo mostra a região do loop da echistatina e de JD49 contendo as seqüências RGD e ECD, respectivamente. Os resíduos RGD estão coloridos em lilas e os ECD em preto. 


\section{- Obtenção do fragmento JD49 livre da fusẫo com GST:}

Para obtermos JD49 livre, inicialmente produzimos a proteina de fusão GST/JD49 por indução das culturas de BL2! transformadas com o clone pKD31. A proteína de fusão foi então isolada por afinidade à glutationa Sepharose 4B (Amersham Biosciences) e posteriormente submetida a clivagem com trombina. A clivagem da proteína de fusão com trombina foi padronizada com respeito a temperatura, tempo e concentração de enzima utilizada. Em todos os casos a padronização foi analisada por SDS-PAGE $18 \%$. Foram utilizadas $0,03 \mathrm{U}, 0,3 \mathrm{U}$ e $0,65 \mathrm{U}$ de trombina na clivagem de $30 \mu \mathrm{g}$ de proteina recombinante Estas reações foram realizadas tanto a $37^{\circ} \mathrm{C}$ por $2 \mathrm{~h}$ como a $23^{\circ} \mathrm{C}$ durante $16 \mathrm{~h}$, onde pudemos verificar que a clivagem foi mais eficiente utilizando $0,65 \mathrm{U}$. Foi então que passamos a avaliar esta concentração e temperatura a diferentes tempos de incubação $(12,16,24$ e 36 h. $)$ Os resultados mostraram uma melhor clivagem com 16 h de incubação. Nestas condições de 0,65 $\mathrm{U}$ de trombina por $\mathrm{mg}$ de proteina recombinante, a $23^{\circ} \mathrm{C}$ durante $16 \mathrm{~h}$ conseguimos clivar aproximadamente $75 \%$ da proteina de fusão (fig. 21 , fileira 4).

\section{- Isolamento de JD49 por HPLC:}

Com a finalidade de isolar JD49 da GST e da proteína de fusão não clivada GST/JD49 (figura 21, fileira 4) e especialmente da trombina usada na clivagem, passamos a purificar esta fração por cromatografia de fase reversa em HPLC segundo protocolo anteriormente descrito para o isolamento das RGD disintegrinas de 49 resíduos, eristostatina e echistatina (McLane e col, 1994). A figura 20 mostra o perfil cromatográfico em coluna C-18. Seis picos foram eluídos à medida que o gradiente de acetonitrila aumentava e foram analisados por SDS-PAGE $18 \%$. Nos picos eluídos aos 7,9 e 12 min não apareceu banda alguma; o material eluído aos 26 min corresponderia à trombina segundo isolamentos anteriores com enzimas tipo trombina isoladas do veneno de B. jararaca no mesmo tempo de retenção; e por último o pico eluido aos $32 \mathrm{~min}$ corresponde a GST e GST/JD49. O material eluído aos $20 \mathrm{~min}$, sinalizado com a seta, foi o único que apresentou uma banda correspondente a JD49 (Fig.21, fileira 4). 


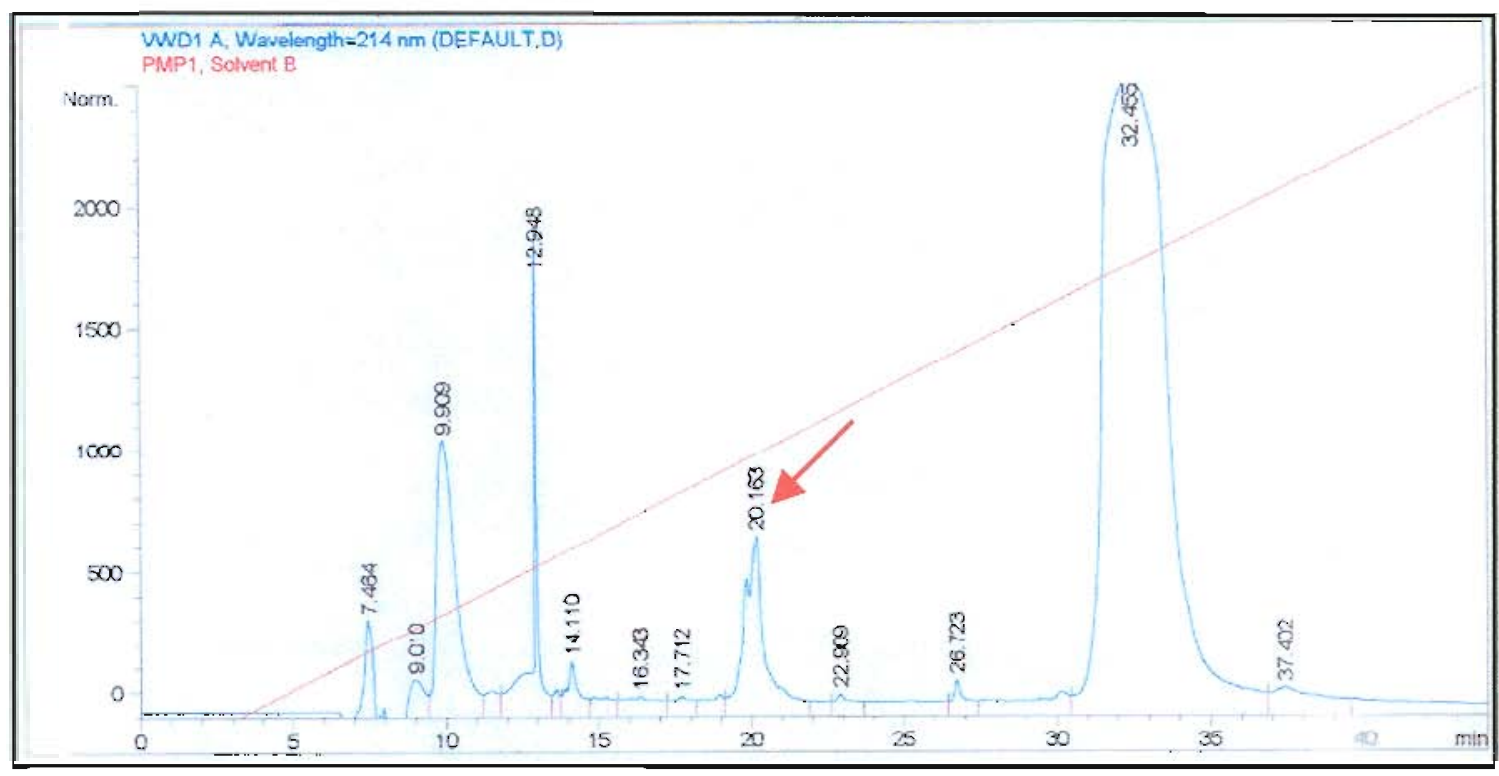

Fig. 20. Isolamento de JD49 por HPLC. A porção JD49 clivada foi obtida em sistema de HPLC em coluna de fase reversa C18 (Vydac, Hesperia, USA) equilibrada em $0,1 \%$ de TFA (Ácido Tri Fluoroacético) e eluída por um gradiente de acetonitrila de 0 a $80 \%$ em volume de $40 \mathrm{~mL}$ a um fluxo de $2 \mathrm{~mL} / \mathrm{min}$. A cromatrografia foi monitorada por absorbância a $214 \mathrm{~nm}$ e as fraçōes reunidas foram analisadas por SDS-PAGE $18 \%$ quanto à presença de uma banda de baixa massa molecular ( 5 $\mathrm{kDa}$ ) que corresponde a JD49 isolada

A figura 21 abaixo mostra todas as etapas envolvidas na purificação de JD49. Na primeira fileira podemos observar o extrato bacteriano, produto da expressão do clone pKD31, contendo GST/JD49 (32 kDa). A fileira 2 corresponde à purificação por afinidade deste material com glutationa Sepharose 4B, onde podemos observar a purificação de GST/JD49. $\mathrm{Na}$ fileira 3 apresentamos este material clivado com trombina e por último, na fileira 4 , indicada com a seta, podemos ver a banda de $5 \mathrm{kDa}$ correspondente a JD49 purificada por HPLC, que foi concentrada com respeito ao material inicial (terceira banda da fileira 3).

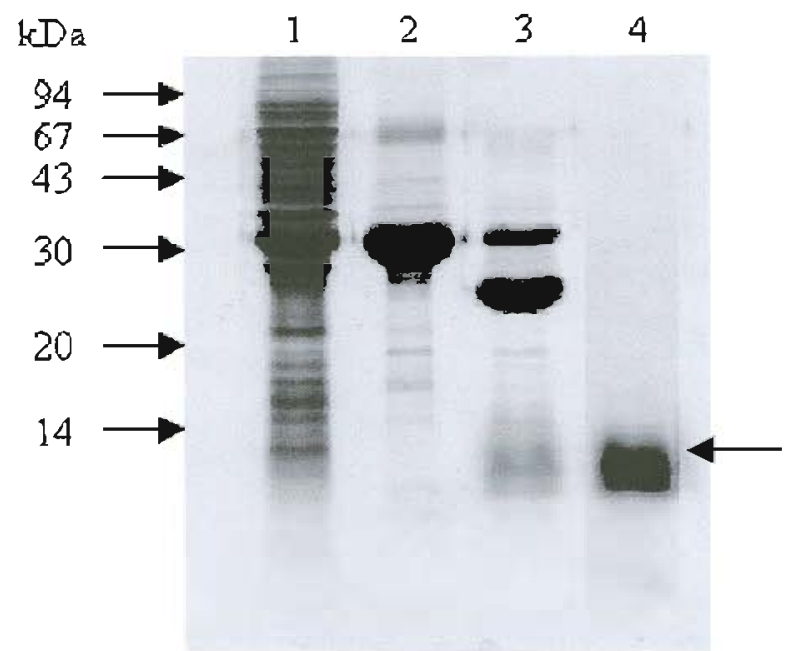

Fig. 21. Etapas envolvidas na purificação de JD49. Na primeira fileira podemos observar o extrato bacteriano, produto da expressão do clone pKD31. A fileira 2 corresponde à purificação por afinidade deste material com glutationa Sepharose 4B. Na terceira fileira apresentamos este material clivado com trombina; e por último a fileira 4 corresponde ao material isolado em fase reversa. 
- Avaliação da atividade biológica:

Após a purificação de M49 decidimos testar a atividade biológica deste fragmento. Uma vez que JD49 reage fracamente com o anticorpo anti-jararagina, descartamos o teste de dot blot e optamos por avaliar o fragmento quanto à sua habilidade de inibir a agregação plaquetária induzida por colágeno. Nossos resultados mostraram que JD49, purificada por HPLC, não apresentou atividade inibitória (dados nâo mostrados), embora a jararagina, purificada do veneno de $B$. jararaca, inibiu em $100 \%$ a agregação plaquetária, mantendo sua forte atividade disintegrina. Estes dados sugerem que esta regiăo por si só não é suficiente para desenvolver a atividade e que outras porçôes da molécula precisam estar presentes.

Apesar de JD49 não possuir atividade biológica, a reatividade com o anticorpo monoclonal MAJar3 sugere que este fragmento está envolvido na ligação ao colágeno e na atividade hemorrágica da jararagina. Estes dados poderão servir de base para um estudo mais detalhado da jararagina e ainda podem servir como ponto de partida para a elaboração de marcadores moleculares da integrina $\alpha 2 \beta 1$.

\section{MARCADORES MOLECULARES}

Com a finalidade de desenvolver marcadores moleculares seletivos para integrinas, decidimos clonar as disintegrinas no vetor pLIP6-GN que permite a expressão periplásmica de proteinas exógenas em fusão com a fosfatase alcalina de $E$. coli. A eristostatina, de 49 residuos foi selecionada por seu pequeno tamanho e por apresentar seletividade pela integrina $\alpha$ Ilb $\beta 3$ Adicionalmente escolhemos o fragmento JD49, uma vez que demonstramos de forma indireta a participação desta sequência na ligação ao colágeno e na atividade hemorrágica da jararagina. Este produto resultaria em um possivel marcador seletivo para a integrina $\alpha 2 \beta 1$. Embora JD49 não tenha apresentado atividade biológica, acreditamos que o micro ambiente periplásmico facilite a solubilidade e permita a exposição das porções ativas deste fragmento O periplasma bacteriano permitiria assim a correta formação das pontes dissulfeto adquirindo assim uma conformação adequada e atividade biológica preservada. 


\section{PRODUCÃO DE JD49 E DA ERISTOSTATINA:}

\section{- Clonagem:}

Os oligonucleotídeos usados para a amplificação do inserto por PCR foram construídos levando em conta os dois únicos sítios de clonagem do vetor pLIP6-GN: Sfi I (5') e Not I ( $\left.3^{\prime}\right)$, e os 15 primeiros nucleotídeos correspondentes às terminações 5' e 3' dos fragmentos de DNA que codificam as sequêencias de JD49 e eristostatina. As seqüências teoricamente resultantes dessa clonagem foram avaliadas quanto à fase de leitura, com a ajuda do programa ExPASy - Translate tool. No caso do pLIP6-GN era especialmente importante ver se estava em fase tanto a região $5^{\prime}$ (Sfi I), quanto a 3' (Not I) devido ao fato de que o fragmento será inserido dentro do gene $P h o A$ da fosfatase alcalina. Com o programa WebCutter verificamos a ausência dos sítios de restrição para Sfi I e Not I dentro do DNA que codifica nossos fragmentos. Adicionalmente desenhamos os oligonucleotídeos para o seqüenciamento com a ajuda do programa Primer Tool. Estes primers foram construídos levando em conta o começo e o final da seqüència que codifica à fosfatase alcalina presente no vetor, assim mesmo se escolheu uma região onde o relação AT:GC esteja na proporção $1: 1$. O primer pLIPseq 5' anela com a região 1612-1631 do vetor em quanto o primer pLIP5seq3' se localiza na posição $1796-1815$

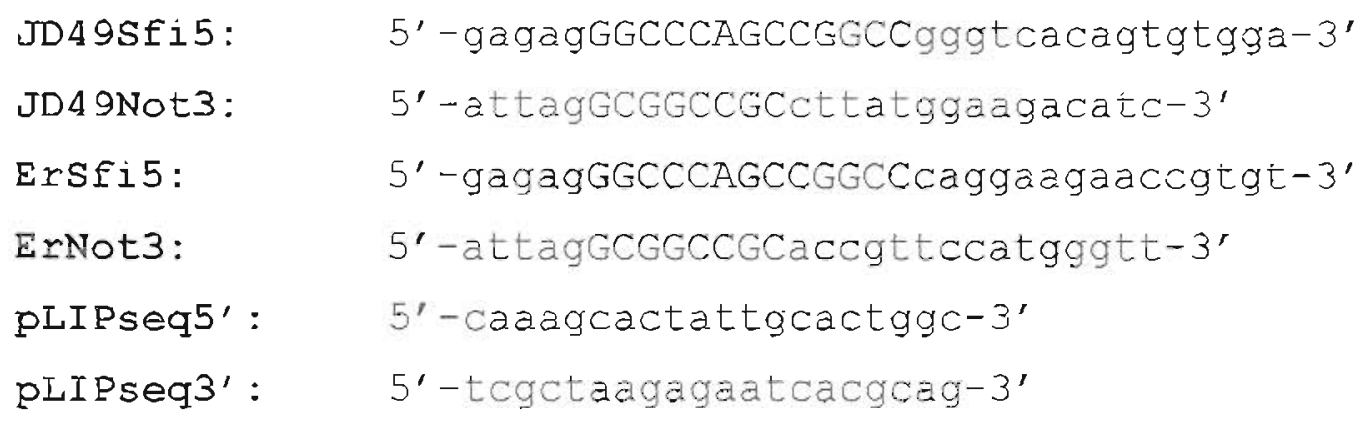

Fig. 22. Oligonucleotideos. Os nucleotídeos em maiúsculas correspondem ao lugar de reconhecimento das endonucleases de restrição. Os nucleotídeos em minúsculas à direita do sítio de restrição correspondem as 15 primeiras bases do DNA a ser amplificado da seqüência da disintegrina tanto do lado $5^{\prime}$ como do lado 3'. Os nucleotideos em minúsculas à esquerda do sítio de restrição correspondem ao lugar de apoio para as endonucleases. 
Os fragmentos de DNA correspondentes a JD49 e a eristostatina foram amplificados seguindo o programa e protocolo descritos em material e métodos. Como moldes utilizamos o cDNA da jararagina no fago $\lambda Z a p I I$ e o clone pGEr contendo o gene sintético da eristostatina, gentilmente cedido pela Dra. Mary Ann McLane. Ao final dos 30 ciclos, a reação foi avaliada em gel de agarose $1 \%$ para verificar a amplificação dos fragmentos. Os produtos de PCR foram digeridos com Not I e Sfi İ. Antes da digestão, estas enzimas de restrição foram testadas em reações independentes onde observamos a clivagem do vetor pLIP6-GN.

Os produtos de PCR foram ligados no vetor pLIP6-GN previamente digerido com as mesmas enzimas e subseqüentemente foram utilizados para transformar $E$. coli DHS $\alpha$ competente. As bactérias foram semeadas em placas de L-agar contendo ampicilina e o substrato de fosfatase alcalina BCIP. Desta forma, a ampicilina selecionou as bactérias transformadas e o substrato BCIP revelou as colonnias azuis contendo o vetor PL,IP6-GN clonado com os insertos de PCR. A clonagem mostrou uma eficiência media com $50 \%$ das colônias positivas (em azul) Alem disso, todas as colônias azuis triadas por PCR mostraram-se positivas amplificando a banda de 150 pb correspondente aos fragmentos clonados. O clone pD7 de JD49 e pE5 da eristostatina tiveram seus insertos completamente seqüenciados confirmando-se a correta inserção de ambas sequêencias no gene PhoA da fosfatase alcalina. A figura 23 mostra a tradução de loda a seqüência usando o ExPASy Translate tool. Os nucleotídeos GGAG em negrito correspondem à seqüência Shine-Dalgarno onde se liga a seqüência 3' terminal do rRNA $16 \mathrm{~S}$ de $E$. coli. A seqüência GTG corresponde à metionina iniciadora e junto com o restante de resíduos sublinhados, forma parte do peptídeo sinal de 21 resíduos. A sequência da fosfatase alcalina madura começa com a arginina $(R)$. Em minúsculas e negrito podemos ver os sitios de restrição que flanqueiam a sequêencia clonada, no quadro. Em vermelho indicados por uma seta estão as regiões onde anelam os primers de seqüência. 


\section{JD49/APv}

GGAGaaataaaGTGaaacaagcactattgcactggdactcttaccgttactgtttaccctgtgacaaaa \begin{tabular}{llllllllllllllllllll}
$M$ & $K$ & $Q$ & $S$ & $T$ & $I$ & $A$ & $L$ & $A$ & $L$ & $L$ & $P$ & $L$ & $L$ & $F$ & $I$ & $P$ & $V$ & $T$ & $K$ \\
\hline
\end{tabular}

gcccggacaccagaaatgccggcccagccggфcgggtcacagtgtggacatggagactgttgtgagcaatgc

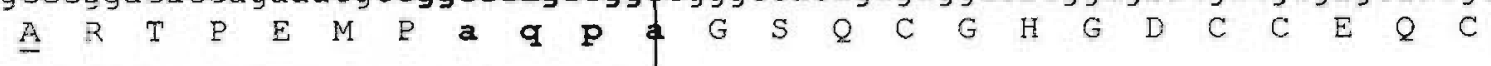
aaatttagcaaatcaggaacagaatgccgggcatcaatgagtgaatgtgacccggctgaacactgcactggo \begin{tabular}{llllllllllllllllllllllll}
$K$ & $F$ & $S$ & $K$ & $S$ & $G$ & $T$ & $E$ & $C$ & $R$ & $A$ & $S$ & $M$ & $S$ & $E$ & $C$ & $D$ & $P$ & $A$ & $E$ & $H$ & $C$ & $T$ & $G$ \\
\hline
\end{tabular} caatcttctgagtgtcctgcagatgtcttccataaggcggccgcagttctggaaaaccgggctgctcagggc

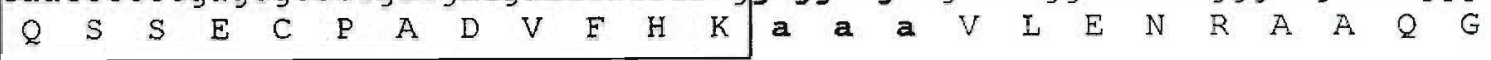

gatattactgcacccggcggtgctcgccgttaacgggtgatcagactgcogct tgcgtgattctcttagc $\begin{array}{llllllllllllllllllllllll}D & I & T & A & P & G & G & A & R & R & L & T & G & D & Q & T & A & A & L & R & D & S & L & S\end{array}$ gataaactgcaaaaatattatttgctgattggcgatgggatgggggactcggaaattactgccgcacgt

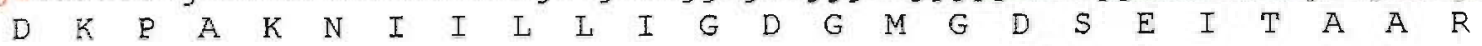
aattatgccgaaggtgcgggcggctttttaaggtatagatgccttaccgcttaccgggcaatacactcac

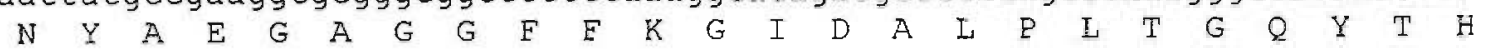

tatgcgctgaataaaaaaccggcaaccggactacgtcaccgac

$\begin{array}{lllllllllllllll}Y & A & L & N & K & K & T & G & K & P & D & Y & V & T & D\end{array}$

\section{Er/APv}

tttaatgtatttgtacatGGAGaaataaaGTGaacaagcactattgcactgg dact.

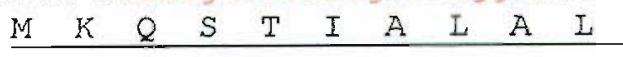

ttta cccetgtgacaaaagcccggacaccagaaatgccggcccagccggcodaggaagaaccgtguyciacd $\begin{array}{llllllllllllllllllllllllll}E & T & P & V & T & K & A & R & T & P & E & M & P & a & q & P & a & Q & E & E & P & C & A & T\end{array}$

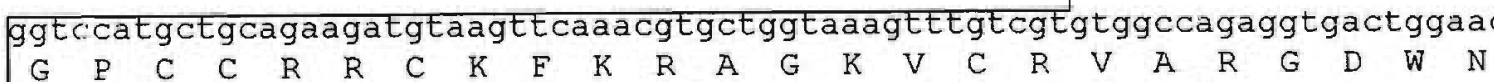
$\begin{array}{llllllllllllllllllllllll}G & P & C & C & R & R & C & K & F & K & R & A & G & K & V & C & R & V & A & R & G & D & W & N\end{array}$ gacgactactgtaccggtaagtcttgtgactgcccgagaaacccatggaacggtgcggcogcagttctggaa \begin{tabular}{llllllllllllllllll|llllll}
$D$ & $D$ & $Y$ & $C$ & $T$ & $G$ & $K$ & $S$ & $C$ & $D$ & $C$ & $P$ & $R$ & $N$ & $P$ & $W$ & $N$ & $G$ & $a$ & $a$ & $a$ & $V$ & $I$ & $E$
\end{tabular}

aaccgggctgctcagggcgatattactgcacccggcggtgctcgcogtttaacgggtgatcagactgccget

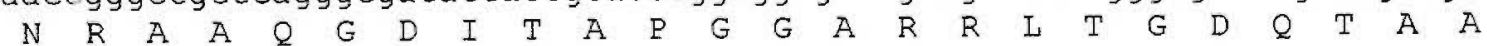

tgcgtgattctct agcgataacctgcaaaaatattatttgctgattggcgatgggatgggggactcg

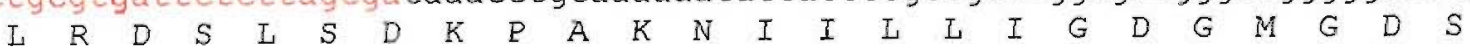
gaattactgccgcacgtaattatgccgaaggtgogggcggct:ttttaaaggtatagatgccttaccgctt

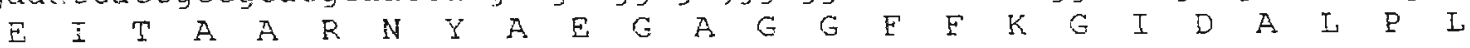
accuggcaatacactcactägcgctgaataaaaaacoggcaaccggactacgtcaccgactcggctgca

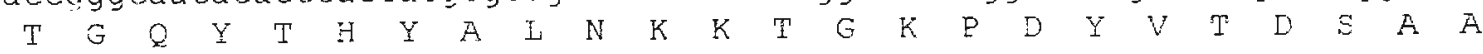


Figura 23. Tradução do DNA sequenciado usando o ExPASy Translate tool. Os residuos GGAG em negrito correspondem à seqüência SD (Shine-Dalgarno) onde se liga a seqüência 3 ' terminal do rRNA $16 S$ de $E$. coli. A seqüência GTG corresponde à metionina iniciadora e junto com o restante de resíduos sublinhados, forma parte do peptideo sinal de 21 resíduos. A arginina 22 (R) dá início à seqüência da fosfatasse alcalina madura. Em minúsculas e negrito podemos ver os sítios de restrição que flanqueiam a seqüência clonada, no quadro. Em vermelho indicados por uma seta estão as regiões onde anelam os primers de sequiência.

\section{- Expressão:}

Inicialmente padronizamos a produção de nossas proteinas recombinantes em 4 cepas distintas de E. coli: BL21, BL21(DE3), CC118 e AD494(DE3). Nossos resultados mostraram uma maior quantidade de proteína solúvel na expressão em BL21. Esta bactéria foi utilizada para padronizar a concentração de IPTG, tempo e temperatura de indução ideal resultando nos valores de $100 \mu \mathrm{M}$ de IPTG a $37^{\circ} \mathrm{C}$ durante 4 horas. Em todos os casos as bacterias foram submetidas a choque osmótico e foi medida a concentração protéica dos extratos solúveis. $\mathrm{O}$ critério de avaliação foi baseado na atividade fosfatase alcalina de concentrações iguais de proteína periplásmica. Utilizando estas condições de indução, preparamos novas culturas para assim compararmos a atividade fosfatase alcalina, as bandas de migração em SDS-PAGE e os antígenos revelados por Western Blotting dos produtos do pLIP6, do pD7 (JD49/APv) e do pE5 (Er/APv), induzidos ou não induzidos

O SDS-PAGE feito com as proteínas obtidas nestas condições ideais é apresentado a seguir. Foram aplicadas $10 \mu \mathrm{g}$ de proteina por fileira. Na primeira fileira pode-se ver o padrão de massa molecular, a segunda fileira corresponde às proteínas da bactéria vazia, a terceira e quarta fileiras correspondem à migtação do pLIP6 sem induzir e induzido, respectivamente. Como esperado, a banda de $45 \mathrm{kDa}$ correspondente à fosfatase alcalina de $E$. coll não está presente, devido ao fato do DNA que codifica esta proteina não estar em fase de leitura. A fileira 5 corresponde ao pD7 não induzido e a 6 ao induzido, é possível verificar o produto de expressão correspondente ao fragmento JD49 em fusão com a fosfatase alcalina de E. coli (62 $\mathrm{kDaj}$. Nas fileiras 7 e 8 podemos ver os produtos correspondentes ao clone pE5 não induzido e induzido, respectivamente, onde podemos ver neste último a banda de $62 \mathrm{kDa}$ correspondente a Er/APv. A fleira 9 corresponde à fosfatase alcalina, produto do vetor pLIP5 induzido. 


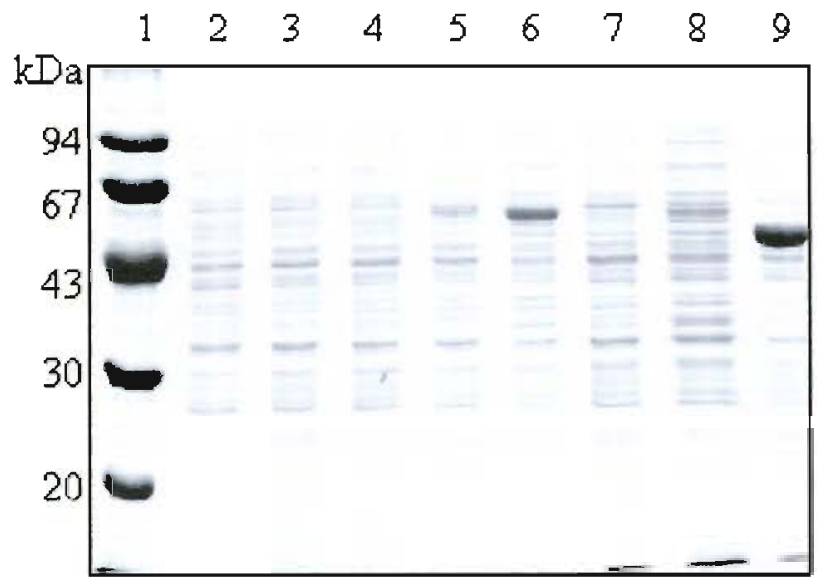

Figura 24. Análise de expressão das proteínas de fusão. Os clones pD7 e pE5 foram induzidos com IPTG, os extratos periplásmicos extraidos e avaliados por SDS-PAGE $12 \%$ quanto à expressão de JD49/APV (6) e Er/APv (8). Na primeira fileira podemos observar o padrão de massa molecular. Como controles utilizamos o extrato periplásmico. correspondente a BL21 vazia (2), o produto de expressão do vetor pLIP6 sem induzir (3) e induzido (4), os clones pD7 (5) e pE5 (7) não induzidos e por último o produto do vetor pLIP5 induzido (9).

Os resultados de SDS-PAGE foram confirmados por Western blot utilizando anticorpos antijararagina, eristostatina e fosfatase alcalina de E. coli produzidos em coelho. A figura 25 mostra o Western blot utilizando o anticorpo policlonal anti-jararagina onde podemos verificar uma banda mais intensa de $62 \mathrm{kDa}$ correspondente a JD49 em fusão com APv (4). Os controles de vetor vazio $(1,2,7)$, clone $\operatorname{pE5}(5,6)$ e clone pD7 não induzido (3) mostram uma banda do mesmo tamanho, mas de menor intensidade que provavelmente corresponde a algum antígeno de E. coli reconhecido pelo soro. Como alternativa, repetimos o teste com soro anti-jararagina previamente adsorvido com antígenos de $E$. coli obtendo os mesmos resultados (dados não mostrados).

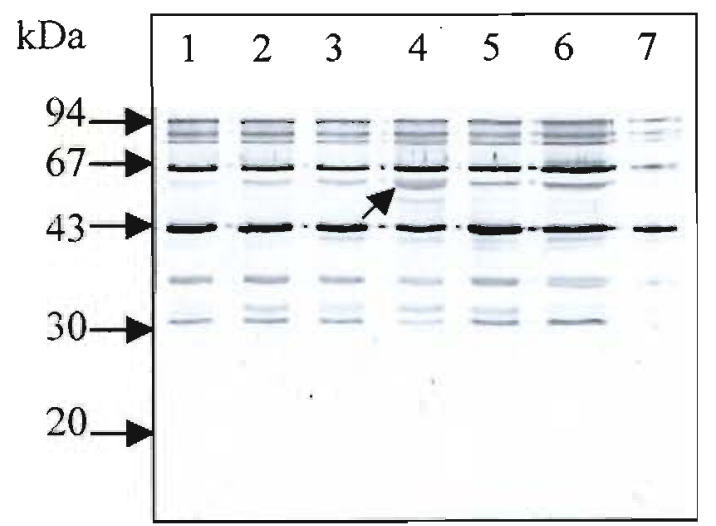

Figura 25. Análise de expressão de JD49/APv por Western blot. As proteínas de fusão foram analisadas por Western blot utilizando $o$ anticorpo anti-jararagina. Como controles utilizamos o vetor pLIP6 sem induzir (1) e induzido (2), o clone pD7 não induzido (3), o clone pE5 não induzido (5) e induzido (6) e o vetor pLIP5 induzido (7). $\mathrm{Na}$ fileira 4 podemos observar a banda de 62 $\mathrm{kDa}$ correspondente a JD49/APV, produto do clone pD7. 
A figura 26 corresponde à incubação do produto de expressão $(5 \mu \mathrm{g}$ de proteína por fileira) com soro policlonal anti-eristostatina. O canal 1 corresponde ao extrato periplásmico de $E$. coli, o canal 2 e 3 correspondem ao pLIP6-GN induzido e sem induzir, respectivamente. $\mathrm{O}$ canal 4 e 5 corresponde ao clone pD7 induzido e sem induzir, respectivamente. No canal 7 (pE5 induzido) pode ser verificada a banda de $62 \mathrm{kDa}$ correspondente a proteína de fusão Er/APv. No canal 6 correspondente ao pE5 sem induzir se pode ver uma pequena expressão basal da proteína de fusão. Como controle negativo o canal 8 apresenta o produto de expressão do clone pE5.
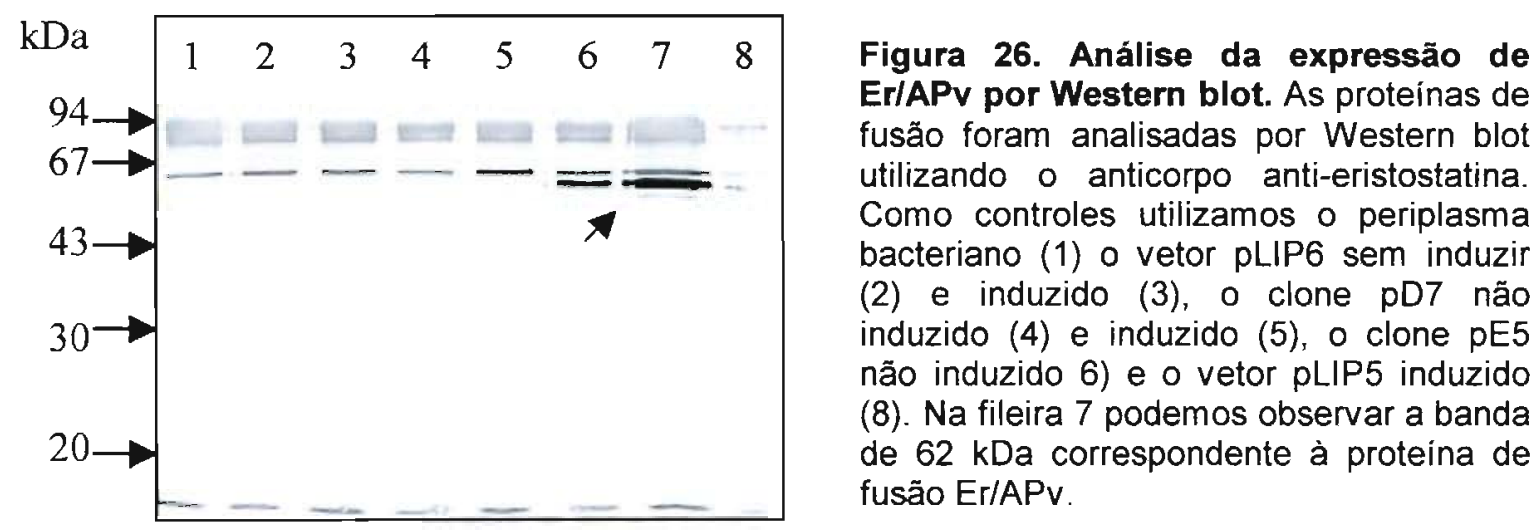

Adicionalmente, avaliamos ambos os fragmentos de fusão utilizando soro policlonal antifosfatase alcalina de $E$. coli. Os dados (fig. 27) mostram claramente que tanto a banda correspondente a JD49/APv (5), Er/APv (7) como APv (8) foram identificadas com o soro demonstrando a preservação de sua antigenicidade. Os controles de clones não induzidos (4, 6) apresentaram bandas fracas de $62 \mathrm{kDa}$ correspondentes a um vazamento da expressão. Como controles negativos utilizamos periplasma bacteriano (1), pLIP6 não induzido (2) e induzido (3). 


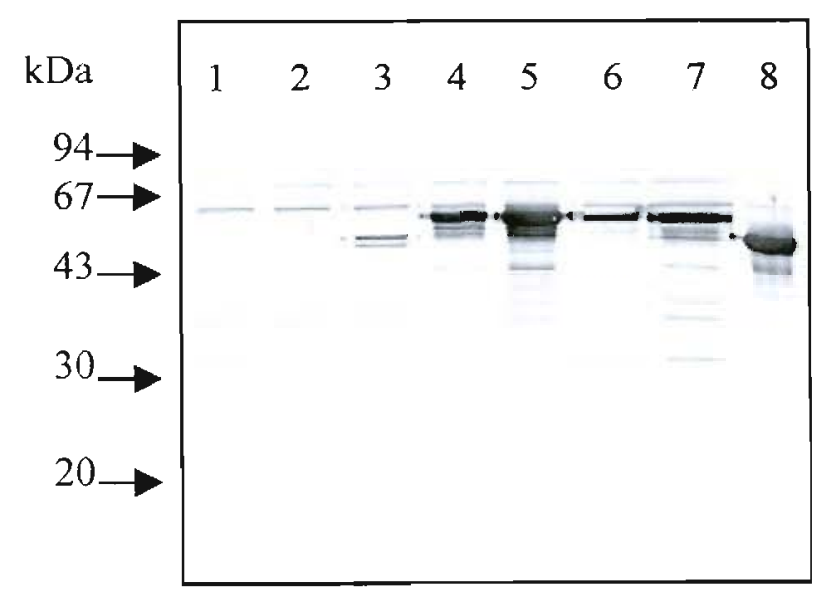

Figura 27. Análise da expressão das proteínas de fusão por Western blot. As proteinas de fusão foram analisadas por Western blot utilizando o anticorpo anti-fosfatase alcalina. Como controles negativos utilizamos o periplasma bacteriano (1) o vetor pLIP6-GN sem induzir (2) e induzido (3); e os clones pD7 (4) e pE5 (6) não induzidos. Como controle positivo utilizamos o vetor pLIP5-GN induzido (8). As fileiras 5 e 7 correspondem aos clones pD7 e pE5 induzidos, respectivamente.

\section{- Dosagem protéica das disintegrinas de fusão:}

Bactérias E. coli BL21 contendo os clones pD7 e pE5 foram cultivadas e, após indução, as proteínas periplásmicas foram extraídas. Na figura 28 podemos ver o produto do clone $\mathrm{pD} 7$ (1) apresentando uma banda intensa de $62 \mathrm{kDa}$ correspondente a JD49/APv. Na coluna 2, podemos ver a banda da mesma migração pertencente a Er/APv (clone pE5) e na coluna 3 visualizamos a banda de APv (pLIP5). Uma vez que nossas proteínas de fusão não estavam puras e sim contaminadas com proteínas periplásmicas era impossível quantificá-las por métodos convencionais. Foi então que decidimos quantificar especificamente as bandas correspondentes a nossas disintegrinas em fusão utilizando medida de densitometria da banda no sistema Eagle Eye (Stratagene). Nas colunas 5 a 9 estão presentes as bandas correspondentes a 0,$05 ; 0,1 ; 0,2 ; 0,4 ; 0,8$ e $1,6 \mu \mathrm{g}$ de BSA. Os valores calculados para JD49/APv, Er/APv e APv resultaram em 140, 20 e $800 \mathrm{ng}$ de proteína de fusão por $\mu \mathrm{L}$ de periplasma.

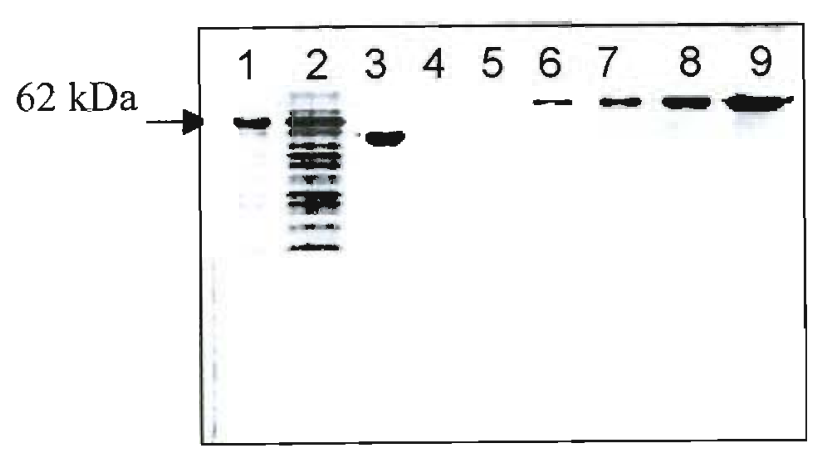

Fig. 28. Dosagem protéica. Os extratos periplásmicos correspondentes aos clones pD7 (1), pE5 (2) e ao plasmídeo pLIP5-GN (3) foram fracionados por SDSPAGE $12 \%$ junto com bandas de concentração conhecida de albumina indo de 0,05 a 1,6 $\mu \mathrm{g}$ (fileiras 4-9). Utilizando o sistema Eagle Eye (Stratagene) foi construida uma curva com os valores obtidos de BSA e a concentração das bandas de JD49/APv (1), Er/APV (2) e APv (3) foi estimada através da comparação por densitometria. 


\section{ATIVIDADE BIOLÓGICA:}

\section{- Atividade fosfatase alcalina.}

A atividade fosfatase alcalina foi testada em um ensaio de Western blot onde revelamos as proteínas periplásmicas diretamente com o substrato NBT/BCIP. Para tanto, utilizamos $4 \mu \mathrm{g}$ do extrato periplásmico por pocinho. Na figura 29 mostramos as proteínas recombinantes e seus controles. A fileira 1 corresponde aos extratos periplásmico de BL21 e as fileiras 2 e 3 correspondem ao vetor pLIP6 sem induzir e induzido, onde se pode comprovar a ausência de bandas positivas para a atividade fosfatase alcalina ( $p h o A$ fora de fase de leitura); nas fileiras 4 e 5 correspondentes ao clone pD7 sem induzir e induzido pode-se ver um aumento em intensidade da banda de $62 \mathrm{kDa}$ (JD49/APv) correspondente ao clone induzido; no caso do clone $\mathrm{pE} 5$, esta banda (Er/APv) só se visualiza fracamente após indução (7); na fileira 8 podemos ver a banda correspondente à fosfatase alcalina (APv), produto do vetor pLIP5 (phoA em fase de leitura). Estes resultados mostram: primeiro, que nossas proteínas híbridas mantêm sua atividade fosfatase alcalina após serem submetidas a fracionamento eletroforético, e segundo, se compararmos com o SDS-PAGE (figura 24), podemos ver que entre todas as proteínas periplásmicas esta atividade é exclusiva de nossas proteínas recombinantes.

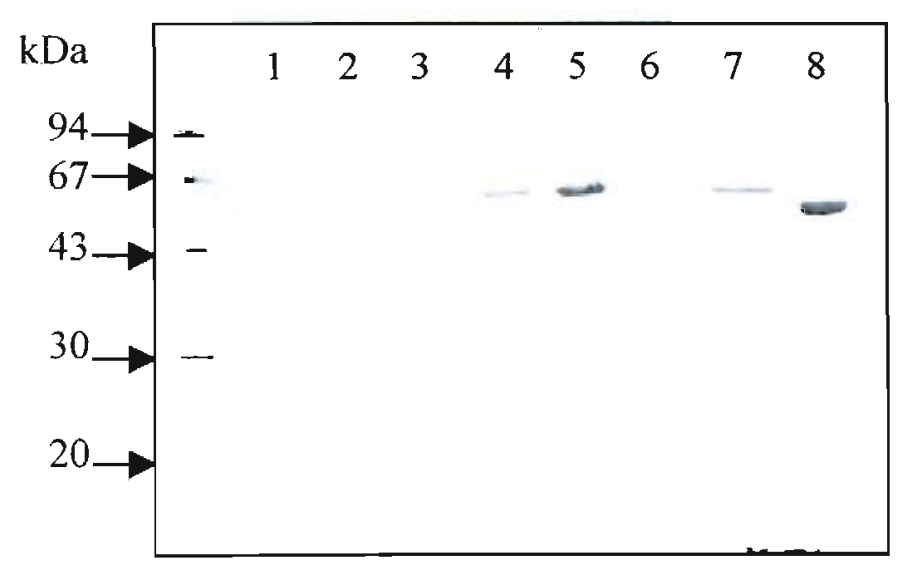

Figura 29. Determinação da atividade fosfatase alcalina das proteínas de fusão. As proteinas de fusão foram fracionadas por SDS-PAGE $12 \%$, transferidas a uma membrana de nitrocelulose e posteriormente reveladas com o substrato NBT/BCIP da fosfatase alcalina. Como controles negativos utilizamos o periplasma bacteriano (1) o vetor pLIP6 sem induzir (2) e induzido (3); e os clones pD7 (4) e pE5 (6) não induzidos. Como controle positivo utilizamos o vetor pLIP5 induzido (8). As fileiras 5 e 7 correspondem ao produto de indução dos clones pD7 e pE5, respectivamente. Os números à esquerda correspondem às massas moleculares. 


\section{- Determinação da atividade de inibição da agregação plaquetária.}

A habilidade das proteinas de fusão em inibir a agregação plaquetária induzida por ADP e colágeno foi testada como descrito em material e métodos. Como controles utilizamos extrato periplásmico, fosfatase alcalina livre (APv) e um mutante da mesma sem atividade catalitica $(\mathrm{APm})$. Os resultados da tabela 1 mostram que a APv livre inibiu a agregação plaquetária em $100 \%$ impossibilitando assim a determinação da atividade das disintegrinas em fusão com a mesma. O controle APm, não conseguiu inibir esta atividade, o que sugere que a inibição se deva exclusivamente a atividade catalítica da fosfatase alcalina e não a uma interação desta com os receptores de plaqueta. $\mathrm{Na}$ figura 30 , podemos observar que as bandas de $45 \mathrm{kDa}$ correspondentes a $\mathrm{APv}$ e $\mathrm{APm}$ são praticamente idênticas quanto a tamanho, intensidade e imunogenicidade como mostra o SDS-PAGE e Western blot revelado com o soro antifosfatase alcalina. Porém, a diferença de $\mathrm{APV}, \mathrm{APm}$ foi incapaz de catalisar o substrato NBT/BCIP e revelar a banda de $45 \mathrm{kDa}$, demonstrando-se assim a ausência de atividade enzimática.

\begin{tabular}{|c|c|c|c|c|c|}
\hline Proteína & Periplasma & JD49/APv & Er/APv & APv & APm \\
\hline ADP & 0 & $89 \%$ & $100 \%$ & $100 \%$ & 0 \\
\hline Colágeno & 0 & $78 \%$ & $100 \%$ & $98 \%$ & 0 \\
\hline
\end{tabular}

Tabela1. Inibição da agregação plaquetária. A tabela mostra a porcentagem de inibição da agregação plaquetária por parte das disintegrinas de fusão e os controles. A linha superior corresponde às proteínas testadas; a segunda linha corresponde aos ensaios com ADP como indutor da agregação e a última linha aos ensaios utilizando colágeno como indutor.

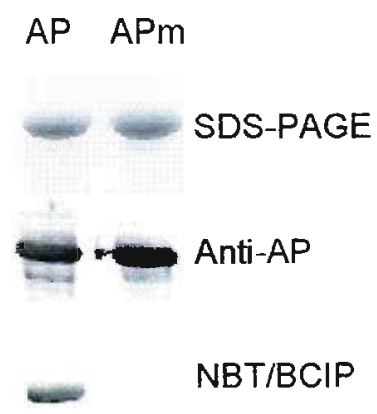

Figura 30. Caracterização da fosfatase alcalina mutante (APm). A expressão de APm foi caracterizada por SDS-PAGE e Western bloting utilizando soro anti-fosfatase alcalina e a atividade catalítica foi determinada com o substrato NBT/BCIP. Como controle utilizamos APv. 


\section{- Teste de dot blot direto utilizando JD49/APv e Er/APv:}

Como alternativa ao teste de agregação plaquetária estabelecemos um ensaio de dot blot para assim poder analisar a ligação destas proteínas à integrinas da superficie de plaquetas. Foram aplicados diretamente na membrana de nitrocelulose $3 \mu \mathrm{L}$ de plaquetas ou plasma rico em plaquetas (PRP). As membranas foram bloqueadas e imediatamente incubadas com nossas proteínas recombinantes e seus controles por $1 \mathrm{~h}$ a $37^{\circ} \mathrm{C}$. Após este período, as membranas foram lavadas e reveladas com o substrato cromógeno da fosfatase alcalina NBT/BCIP. Os resultados (fig. 31) mostram que só Er/APv foi capaz de reconhecer tanto o PRP como as plaquetas. Por outro lado, JD49/APv não conseguiu-se ligar nem ao PRP nem às plaquetas sugerindo que não esteja na conformação adequada. Lembrando a primeira parte do trabalho, JD49 apresenta duas cisteínas que estariam formando pontes com cisteínas não inclusas no fragmento. Estas pontes podem ser fundamentais para a formação do arcabouço da proteína e exposição do loop contendo a seqüência ECD.

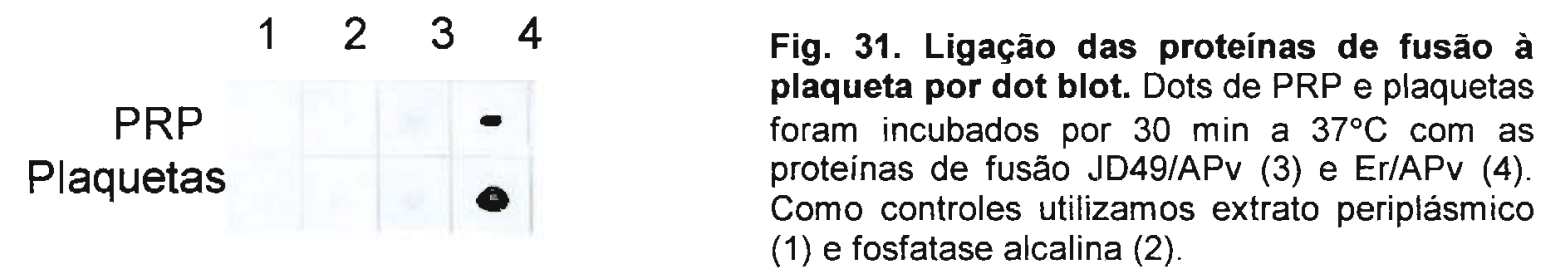

\section{CONSTRUÇÃO DA PROTEÍNA QUIMÉRICA ECD-Er/APv:}

Como alternativa a JD49/APv decidimos construir a proteína quimérica ECD-Er/APv. A diferença de JD49, a seqüência SECDPA estaria inserida no arcabouço da eristostatina que é mais estável e têm suas 8 cisteinas formando 4 pontes dissulfeto. Para tanto, introduzimos mutações pontuais no gene da eristostatina conferindo a substituição dos resíduos contidos no loop. Em principio foi utilizado o kit Quickchange site directed mutagenesis da Stratagene, o qual deu um resultado negativo devido ao excessivo número de substituições previstas. Como alternativa o mutante foi construído com uma modificação do método do megaprimer (Picard e col., 1999). 


\section{- Alinhamento}

Com o objetivo de determinar os resíduos a serem mutados, alinhamos as seqüências protéicas da eristostatina (vermelho) e $\mathrm{D} 49$ (azul) (fig. 32) utilizando o programa ClustalW (Thompson e col., 1994). Os símbolos (*), (:) e (.) correspondem a identidade, alta e baixa homologia, respectivamente. A figura também inclui as pontes dissulfeto onde podemos verificar que diferentemente da eristostatina, JD49 apresenta 2 cisteínas livres. Em negrito estão representados os resíduos pertencentes à região do loop de ambas as proteinas onde podemos ver que compartilham a arginina, sendo que JD49 tem um resíduo a mais na posição 32, o que indica que no total teriamos que substituir 10 aminoácidos e inserir um. Abaixo está representada a quimera ECD-Er onde podemos observar o loop de JD49 mantido na estrutura da eristostatina

JD49

Eristostatina

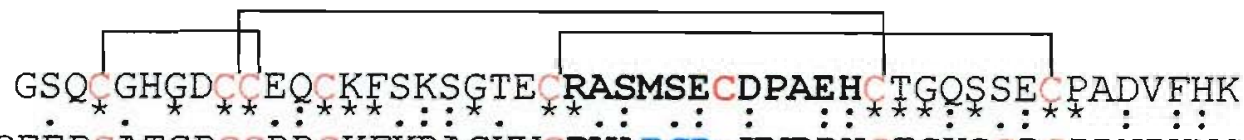

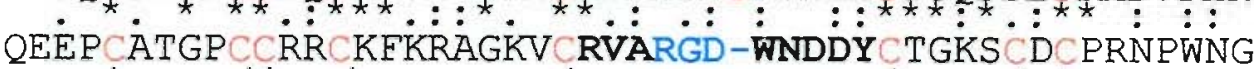
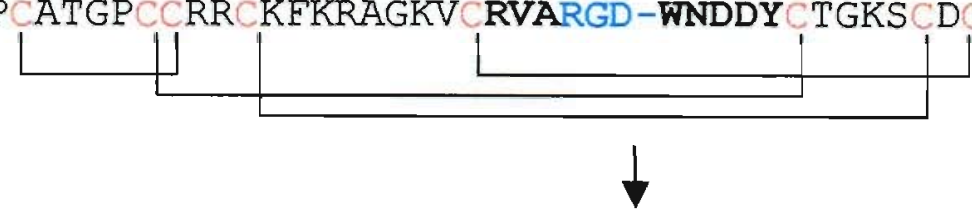

ECD-

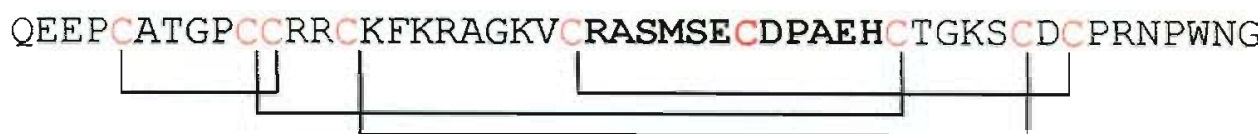

Fig. 32. Alinhamento das seqüências protéicas da eristostatina e JD49. As seqüências foram alinhadas com o programa Clustal W. Os símbolos $\left(^{*}\right)$, (:) e (.) correspondem a identidade, alta e baixa homologia, respectivamente. Em negrito estão os resíduos correspondentes à região do loop. As cisteínas estão marcadas em vermelho e as pontes dissulfeto diagramadas com uma linha. $\mathrm{Na}$ seqüência da quimera está representada o loop de JD49 na estrutura da eristostatina com as 4 pontes dissulfeto. 
$\mathrm{Na}$ figura 33 mostramos os aminoauldos do loop da eristostatina (linha 1) com seus nucleotídeos correspondentes (linha 2). Na linha 3 mostramos os nucleotídeos da eristostatina com 11 substituições (vermelho) e 3 inserções (azul), número mínimo de alterações que dariam origem aos aminoácidos da região do loop de JD49 (linha 4). Este número mínimo de mutações foi selecionado sem deixar de levar em consideração a freqüência de codons para cada aminoácido presente em E. coli (Nakamura e col., 1998).

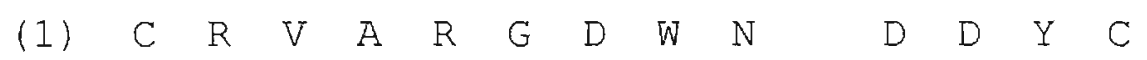

$$
\begin{aligned}
& \text { Er: (2) tgtcgtgtggccagaggtgactggaac---gacgactactgt } \\
& \text { JD49: (3) tgtcgtgcatccatgagtgaatgtgacccggccgaacactgt }
\end{aligned}
$$

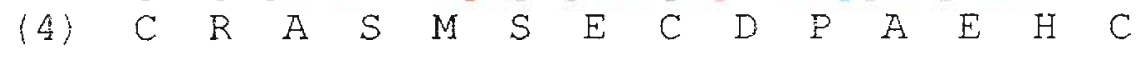

Fig. 33. Nucieotídeos a serem mutados. Nas linhas 1 e 2 mostramos as seqüências protéicas e de DNA da região do loop da eristostatina, respectivamente. Na linha 3 mostramos o mínimo de substituições (vermelho|) e inserções (azul) necessárias para originar o loop de JD49 (linha 4).

\section{- Desenho do megaprimer:}

Baseando-nos no alinhamento dos resíduos dos loops da eristostatina e JD49, desenhamos o megaprimer antisense, de 99 nucleotídeos, que incluía as 11 substituições (vermelho) e 3 inserções (azul) no centro, flanqueadas por 10 nucleotídeos no extremo 3' e seguidos no lado 5' dos resíduos correspondentes ao C-terminal da eristostatina, incluindo-se o sítio de restrição para Not I (negrito) e as bases de apoio para esta mesma (sublinhado). Este oligonucleotídeo foi purificado por PAGE para evitar interferências durante a amplificação por parte de fragmentos menores.

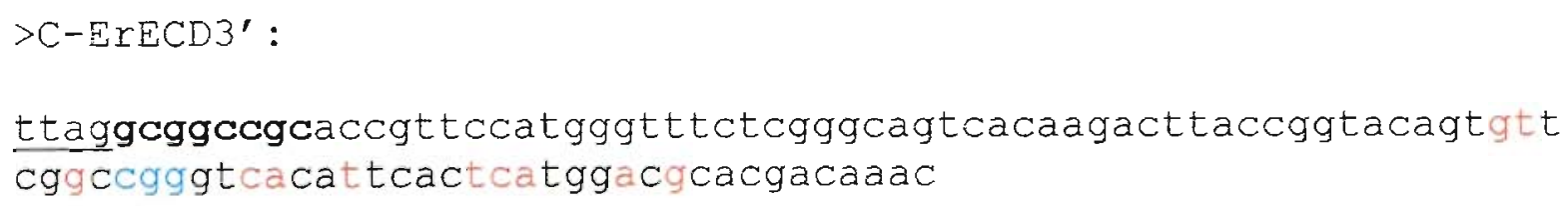

Fig. 34. Megaprimer C-ErECD3' onde podemos ver os nucleotideos a serem substituidos em vermelho $e$ os nucleotídeos a serem inseridos em azul. Os nucleotídeos em preto são complementares ao template sendo que os residuos em negrito correspondem ao sítio de restrição e os sublinhados as bases de apoio para Not $\mathrm{I}$. 


\section{- Reação de PCR:}

Foi feita uma primeira reação de PCR utilizando os primers Eris5Sfi e C-ErECD3'. Como controle positivo fizemos uma reação com os primers Eris5Sfi e Eris3Not e como controle negativo fizemos uma reação sem primers. Em todos os casos utilizamos como template o clone pE5 (gene da eristostatina clonado no vetor pLIP6). A banda resultante desta reação de $150 \mathrm{pb}$ apareceu muito fraca (fig. 35, fileira 5). Para resolver este problema decidimos usar maior tempo de anelamento para favorecer a aderência do megaprimer com o template. Foi assim que dobramos o tempo de anelamento para 2 minutos e repetimos a reação de PCR utilizando os mesmos controles. Na figura 35, podemos ver o padrão de massa molecular (1), seguido das bandas de $150 \mathrm{pb}$ dos produtos de PCR correspondentes à ECD-Er (2) e a eristostatina (3). O controle negativo (4) corresponde a uma reação sem primers. Como podemos observar, a banda correspondente à reação de PCR submetida a $2 \mathrm{~min}$. de anelamento (2), embora apareça mais intensa do que a submetida a um minuto (5), não foi o suficientemente intensa para ser usada na clonagem.

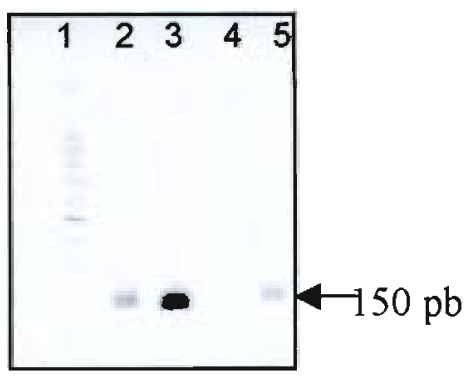

Fig. 35. Produtos de PCR
correspondentes à quimera.
Podemos ver em 1 o marcador de
massa molecular, seguido do
produto de $150 \mathrm{pb}$ correspondente à
quimera (2) e a eristostatina (3). A
fileira 4 corresponde ao controle
negativo e a 5 à banda da quimera
da reação de PCR anterior.

Devido à baixa quantidade do gene mutante produzido por PCR, decidimos usar esta banda como template e amplificá-la por PCR utilizando os primers Eris5Sfi e Eris3Not. Para isso, isolamos esta banda do gel e a purificamos utilizando o Mermaid kit. Nesta purificação perdemos cerca de $60 \%$ do material, deixando a banda quase imperceptivel no gel (dados não mostrados). Posteriormente, realizamos 5 reações de PCR, utilizando o produto purificado como template, e obtivemos uma forte banda de $150 \mathrm{pb}$ correspondente a ECD-Er (dados não mostrados).

O produto de PCR correspondente ao DNA de ECD-Er foi então clonado no vetor pLIP6-GN seguindo os procedimentos descritos para JD49 e Er. Para facilitar a triagem das colônias, bactérias E. coli DH5 $\alpha$ transformadas foram semeadas em TSB-Agar contendo $40 \mathrm{mg} / \mathrm{L}$ de 
BCIP, $100 \mu \mathrm{M}$ de IPTG, e 2,5 $\mu \mathrm{g}$ de ampicilina. Nas placas semeadas pudemos constatar que $28 \%$ das colônias eram azuis, correspondendo às bactérias transformadas com os produtos de ligação ( $P$ hoA em fase de leitura). As colônias brancas correspondiam às bactérjas transformadas com o vetor pLIP6-GN (PhoA fora de fase de leitura).

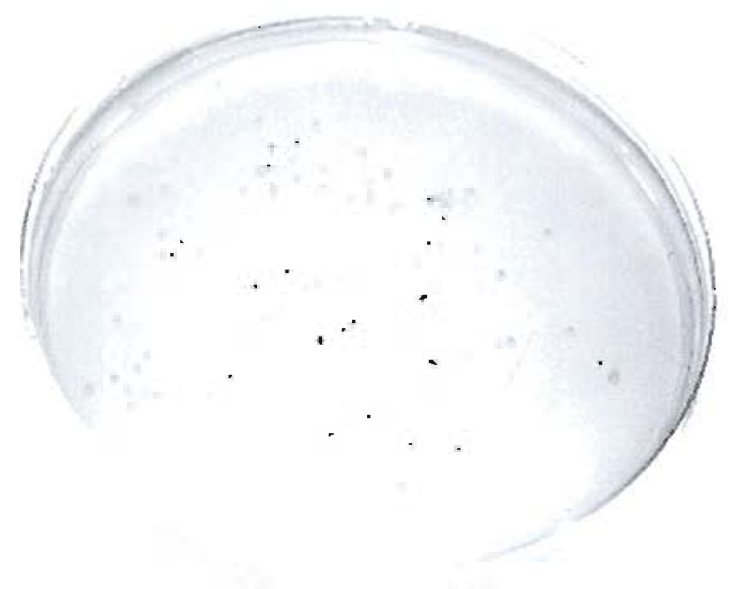

Fig. 36. Seleção de colônias positivas em placas de cultura. Placas de TSB-agar contendo $40 \mathrm{mg} / \mathrm{L}$ de BCIP, 100 $\mu M$ de IPTG, e $2.5 \mu \mathrm{g}$ de ampicilina foram utilizadas para semear a bactéria transformada e os controles. O substrato BCIP foi catalisado pelas colônias que restituíram o gene PhoA da fosfatase alcalina, gerando assim uma coloração azul.

\section{- Triagem das colônias por PCR:}

Com a finalidade de verificar a presença do mutante nestas colônias, construímos o primer 5'ECD, correspondente aos resíduos SECDPA do loop de JD49.

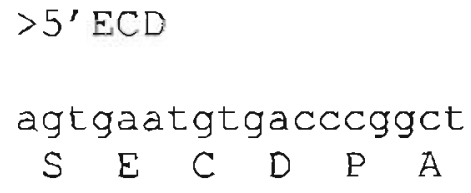

Sete colônias azuis foram triadas por PCR utilizando o primer $5^{3} \mathrm{ECD}$ (sense) que anelaria com a região central do loop de JD49 e o primer pLIPseq3' que anelaria no pLIP6 a 108 nucleotídeos downstream da região de clonagem. Como controle negativo usamos de template o clone pE5 (eristostatina clonada no pLIP6) e como controle positivo o clone pD7 (JD49 clonado no pLIP6). Na figura 38, primeira fileira, podemos observar o padrão de massa molecular; as fileiras 2 a 8 correspondem aos amplificados provenientes das 7 colônias; a fileira 9 corresponde ao controle negativo e a 10 ao positivo. A fileira 11 corresponde a uma reação sem template. O resultado mostra que 6 das 7 colônias deram a banda esperada de 180 pb, idêntica à do controle positivo (coluna 10) demonstrando a presença do cDNA
Fig. 37. Primer 5'ECD. A figura mostra os tradução nos aminoácidos SECDPA, pertencentes à região central do loop de JD49. 
correspondente à disintegrina quimérica. $O$ clone 4 , denominado de mut 4 , foi completamente seqüenciado verificando-se a correta construção da quimera e a inserção desta no gene PhoA da fosfatase alcalina. Fste clone foi selecionado para transformar E. coli BL21.

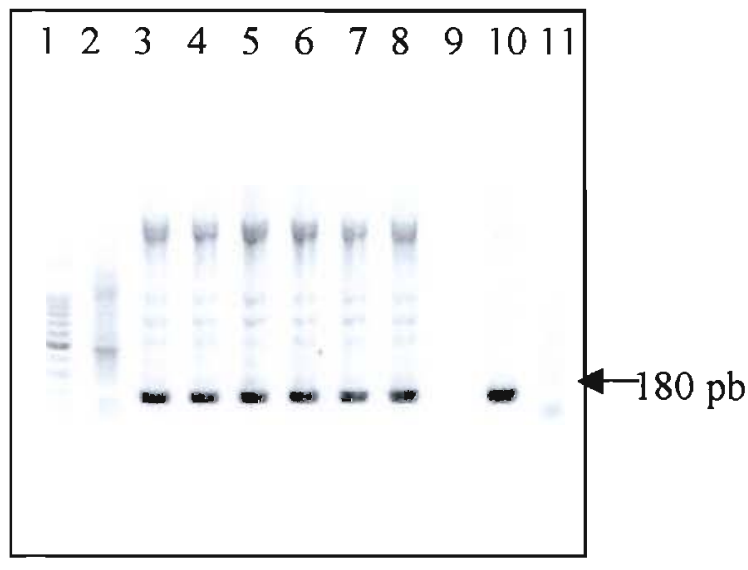

Fig. 38. Triagem das colônias por PCR. No gel podemos observar a migração correspondente ao padrão de massa molecular (1) seguido dos produtos de amplificação de 7 colônias (2-8). Como controle negativo utilizamos o clone pE5 (9) de template e como positivo, o clone pD7 (10). Uma reação sem template foi feita como branco (11).

\section{- Expressão de ECD-Er/APv:}

A expressão foi realizada nas mesmas condições utilizadas para Er/APv. Após extração periplásmica a banda foi identificada por SDS-PAGE e Western blotting utilizando o soro policlonal anti-fosfatase alcalina de $E$. coli. $\mathrm{Na}$ figura 39, primeira coluna, podemos ver a banda de $62 \mathrm{kDa}$ correspondente à quimera ECD-Er/APv. Nas fileiras 2-7 apresentamos valores crescentes de soroalbumina bovina utilizada para construir a curva e determinar a concentração da banda de ECD-Er/APv. A concentração obtida foi de $20 \mathrm{ng} / \mu \mathrm{L}$, valor similar ao obtido para Er/APv.

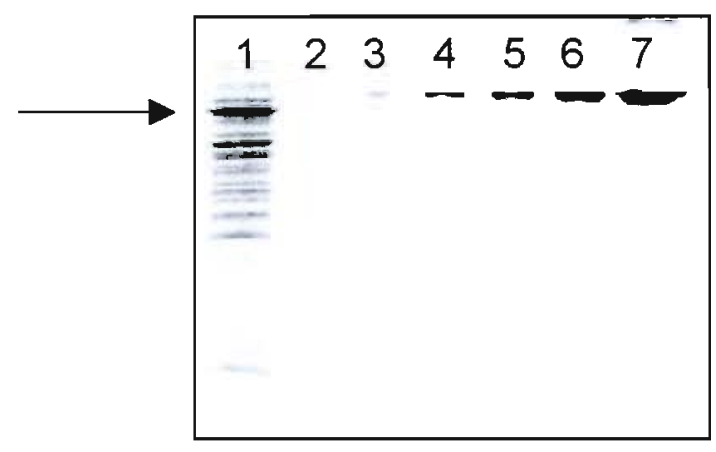

Fig. 39. Expressão de ECD-Er/APv e Dosagem protéica. $O$ extrato periplásmico correspondente ao clone M4 (1) foi fracionado por SDS-PAGE $12 \%$ junto com bandas de concentração conhecida de albumina indo de 0,05 a 1,6 $\mu \mathrm{g}$ (fileiras 2-7). Utilizando o sistema Eagle Eye (Stratagene) foi construida uma curva com os valores obtidos de BSA e a concentração das bandas de ECDEr/APv (1) foi estimada através da comparação por densitometria. 


\section{- Atividade biológica:}

$\mathrm{O}$ extrato periplásmico contendo a proteína de fusão ECD-Er/APv foi analisado por dot blot quanto à sua capacidade de ligar plaquetas e células $\alpha 2-\mathrm{K} 562$ expressando a integrina $\alpha 2 \beta 1$. As membranas foram incubadas por $1 \mathrm{~h}$ a $37^{\circ} \mathrm{C}$ com $3 \mu \mathrm{g} / \mathrm{mL}$ de ECD-Er/APv (1). Como controles, foram utilizados $21 \mu \mathrm{g} / \mathrm{mL}$ de JD49/APv (9), $3 \mu \mathrm{g} / \mathrm{mL}$ de $\mathrm{Er} / \mathrm{APv}$ (8) e $120 \mu \mathrm{g} / \mathrm{mL}$ de APv (10). Na figura 40, podemos ver que só Er/APv (2) manteve sua alta afinidade pelas plaquetas emitindo um sinal positivo. Este resultado mostra por um lado que o loop da eristostatina é fundamental para a ligação as plaquetas, já que sua substituição aboliu totalmente esta afinidade e por outro, que o loop de JD49 não tem uma afinidade evidente pelas plaquetas. Estes resultados foram confirmados com concentrações de ECD-Er/APv de até $10 \mu \mathrm{g} / \mathrm{mL}$, e incubações a temperaturas de 6 e $37^{\circ} \mathrm{C}$ durante tempos de até $16 \mathrm{~h}$. Adicionalmente realizamos testes com os outros 5 clones positivos obtidos (fig. 38). Em todos estes testes, os resultados de dot blot com as quimeras se mostraram negativos (dados não mostrados).

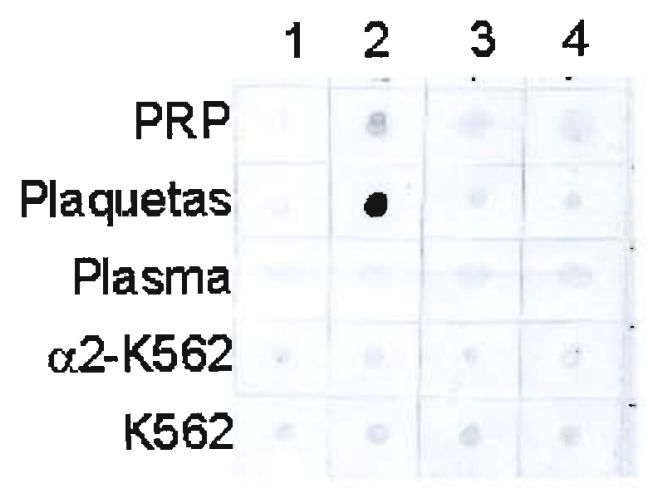

Fig. 40. Análise da atividade de ECDEr/APv por dot blot. Dots de PRP, plaquetas e células $\alpha 2-K 562$ foram incubados com o extrato periplásmico contendo a quimera ECD-Er/APv (1). Como controle negativo das células utilizamos a linhagem K562 e do PRP e das plaquetas, plasma pobre em plaquetas (PPP). Adicionalmente incubamos os dots com Er/APv (2), JD49/APv (3), e APv (4). 


\section{PADRONIZAÇÃo DE Er/APv COMO MARCADOR MOLECULAR}

\subsection{Seletividade de Er/APv para $\alpha$ IIb $\beta 3$ :}

A seletividade da ligação de Er/APv pela integrina $\alpha \operatorname{ll} b \beta 3$ foi avaliada por ensaios de dot blot, utilizando plaquetas e células, e por testes de competição com a eristostatina livre.

\section{- Teste de seletividade por dot blot:}

A seletividade de Er/APv foi testada utilizando plaquetas (1), células K1 (2), A5 (3) e VNRC3 (4). A concentração de células foi ajustada para $4 \times 10^{5} \mathrm{U} / \mathrm{mL}$ e $3 \mu \mathrm{L}$ foram adicionadas por membrana. Os dots foram incubados com $100 \mathrm{ng} / \mathrm{mL}$ de Er/APv (B) durante $1 \mathrm{~h}$ a $37^{\circ} \mathrm{C}$ e revelados durante $2 \mathrm{~min}$. com o substrato NBT/BCIP. Como controle negativo, realizamos uma incubação só com solução bloqueadora (A) e outra com APv (C). Como podemos ver na figura 41, o dot correspondente às células A5 (3B) expressando a integrina $\alpha \operatorname{Ilb} \beta 3$ foi notoriamente reconhecido com respeito às células K1 (2B) e VNRC3 (4B). Assim mesmo, se o compararmos com o controle negativo, podemos evidenciar que o sinal é bem mais intenso que o basal correspondente as células A5 (3A). Como controle positivo podemos observar a forte reatividade de Er/APv com as plaquetas (1B).

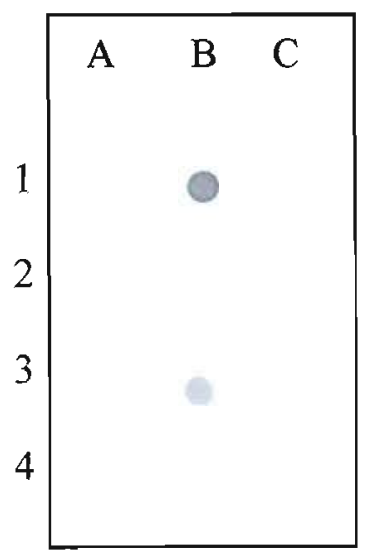




\section{- Teste de competição com eristostatina livre:}

Para verificar se Er/APv estava se ligando ao mesmo receptor que a eristotatina nativa, realizamos um teste de competição por dot blot (fig. 42). Neste caso, utilizamos eristostatina recombinante livre ( $\mathrm{r}-\mathrm{Er}$ ), previamente caracterizada com respeito a sua seletividade pela integrina $\alpha \operatorname{Il} b \beta 3$, por teste de inibição da agregação plaquetária induzida por $\mathrm{ADP}$, mostrando um IC50 de $20 \mathrm{nM}$.

As plaquetas foram incubadas com $0,72 \mu \mathrm{g} / \mathrm{mL}$ de $\mathrm{r}$-Er por $1 \mathrm{~h}$ a $37^{\circ} \mathrm{C}$ (3). Após lavagem, adicionamos $0,2 \mu \mathrm{g} / \mathrm{mL}$ de Er/APv e continuamos a incubação por mais $1 \mathrm{~h}$ a $37^{\circ} \mathrm{C}$. Após a incubação, as membranas foram lavadas e reveladas com o substrato NBT/BCIP da fosfatase alcalina. Como controle negativo e positivo, incubamos as plaquetas só com solução bloqueadora (1) e só com Er/APv (2), respectivamente. $\mathrm{O}$ resultado mostra uma inibição quase total da ligação de $\mathrm{Er} / \mathrm{APv}$ às plaquetas por parte de $\mathrm{r}-\mathrm{Er}$ (3) se o compararmos com os controles, podendo afirmar que Er/APv estaria se ligando ao mesmo receptor que r-Er.

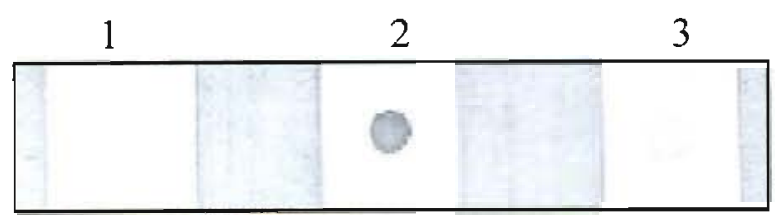

Fig. 42. Teste de competição com eristostatina recombinante isolada. As plaquetas foram reveladas diretamente (1) ou após incubação com Er/APv (2), como controle negativo e positivo, respectivamente. $\mathrm{O}$ dot 3 corresponde à ligação das plaquetas a Er/APv após estas serem incubadas com eristostatina isolada.

\subsection{Conservação da atividade fosfatase alcalina de Er/APv.}

A atividade fosfatase alcalina específica de Er/APv e APv foi comparada a partir de uma curva de atividade construída a partir de diluições seriadas dos recombinantes. Nossos resultados (fig. 43.) mostraram valores similares para ambas as proteínas, sugerindo que toda Er/APv exportada ao periplasma estava enzimaticamente ativa. Desta forma, a inclusão da disintegrina no $\mathrm{N}$-terminal parece não ter alterado a atividade enzimática da porção $\mathrm{APV}$. 


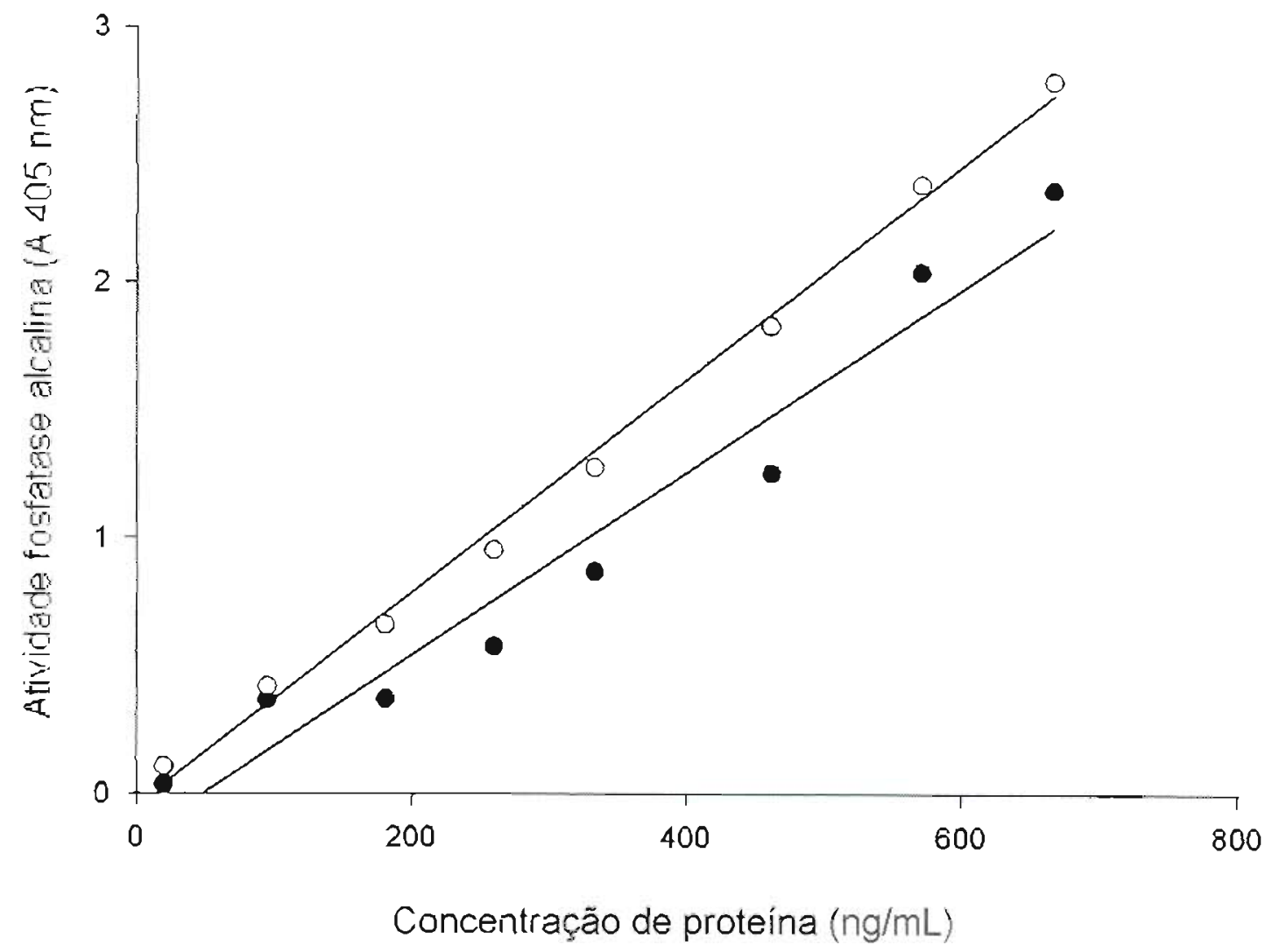

Fig. 43. Comparação da atividade fosfatase alcalina de Er/APv e APv. Diluições seriadas de Er/APv e APV foram aplicadas em placas de ElıISA e subseqüentemente reveladas durante 2 mir. utilizando o substrato pNPP de fosfatase alcalina. As placas foram lidas a $405 \mathrm{~nm}$ e uma curva fc: traçada utilizando-se o programa Sigma Plot, relacionando-se a absorbância com a concentração de proteína.

\subsection{Padronização do teste de dot blot para plaquetas:}

Uma vez determinado que Er/APv se liga às plaquetas e tem atividade AP, passamos a padronizar o teste de dot blot para esta proteina de fusão. Realizamos a padronizaçâo de concentração de proteína e da concentração de plaquetas por dot, tempo e temperatura de incubaçào. 


\section{- Padronização da concentração de Er/APv:}

Realizamos incubações de $1 \mathrm{~h}$ a $37^{\circ} \mathrm{C}$ com concentrações crescentes de Er/APv de $0,5 \mathrm{ng} / \mathrm{mL}$ até $160 \mathrm{ng} / \mathrm{mL}$. Após 2 minutos de revelação podemos constatar, na figura 44, que a intensidade do dot aumenta à medida que aumentamos a concentração de Er/APv. No ensaio podemos observar que com apenas $0,5 \mathrm{ng} / \mathrm{mL}$ de $\mathrm{Er} / \mathrm{APv}$ (2) é possível distinguir marcação em relação ao controle negativo (1), indicando o alto poder de sensibilidade desta proteína de fusão na detecção de integrinas de plaqueta.

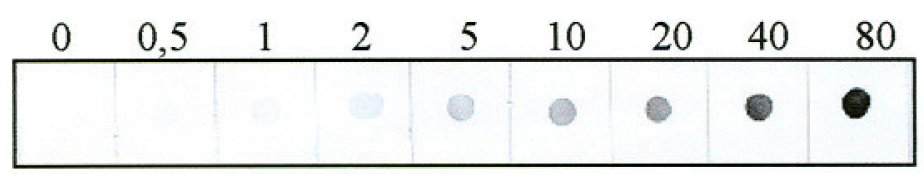

Fig. 44. Padronização do teste de dot blot com respeito à concentração de Er/APv. Dots de plaqueta foram incubados durante $1 \mathrm{~h}$ a $37^{\circ} \mathrm{C}$ com concentrações crescentes de Er/APv e subseqüentemente revelados durante $2 \mathrm{~min}$ com o substrato NBT/BCIP. Os números acima de cada dot indicam a concentração de proteína em $\mathrm{ng} / \mathrm{mL}$ utilizada na incubação.

\section{- Padronização da temperatura de incubação:}

Com respeito à temperatura de incubação, realizamos os testes com $5 \mathrm{ng} / \mathrm{mL}$ de Er/APv por 1 h. a temperatura ambiente $\left(20^{\circ} \mathrm{C}\right), 6^{\circ} \mathrm{C}$ e $37^{\circ} \mathrm{C}$. A temperatura correspondente a $37^{\circ} \mathrm{C}$ foi a mais efetiva para a interação disintegrina-plaqueta.

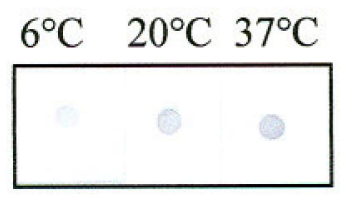

Fig. 45. Padronização do teste de dot blot com respeito à temperatura de incubação. Dots de plaqueta foram incubados durante $1 \mathrm{~h}$ com $5 \mathrm{ng} / \mathrm{mL}$ de $\mathrm{Er} / \mathrm{APv}$ a 6,20 e $37^{\circ} \mathrm{C}$. Logo após as membranas foram lavadas e reveladas durante $2 \mathrm{~min}$ com o substrato NBT/BCIP. Os números acima de cada dot indicam a temperatura utilizada na incubação. 


\section{- Padronização do tempo de incubação:}

Para a padronização do tempo, utilizamos $50 \mathrm{ng} / \mathrm{mL}$ de $\mathrm{Er} / \mathrm{APv}$ a $37^{\circ} \mathrm{C}$ durante tempos de $120,60,30,20,10$ e 5 minutos. A figura 46 mostra que a intensidade do dot é diretamente proporcional ao tempo de incubação e que a reatividade já é evidente em 5 min de incubação.

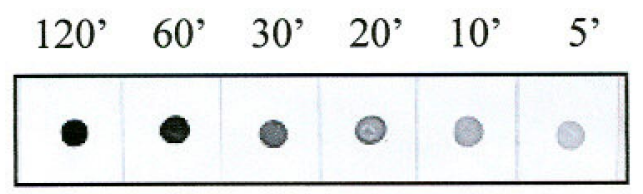

Fig. 46. Padronização do teste de dot blot com respeito ao tempo de incubação. Dots de plaqueta foram incubados a $37^{\circ} \mathrm{C}$ com $50 \mathrm{ng} / \mathrm{mL}$ de Er/APv durante tempos decrescentes indicados acima em minutos. Logo após os dots foram revelados durante 2 min com o substrato NBT/BCIP.

\section{- Padronização da concentração de plaquetas:}

Esta padronização foi realizada para determinar a concentração mínima de plaquetas que permitiria a detecção da interação das mesmas com Er/APv. Para isso, incubamos diluições seriadas de plaquetas $\left(7 \times 10^{8}\right.$ até $11 \times 10^{6}$ plaquetas por $\mathrm{mL}$ ) com $50 \mathrm{ng} / \mathrm{mL}$ de Er/APv durante $1 \mathrm{~h} \mathrm{a} 37^{\circ} \mathrm{C}$. As intensidades dos dots diminuem à medida que diluímos as plaquetas. Como pode ser observado na figura 47 , podemos visualizar a marcação a partir de $2 \times 10^{7}$ $\mathrm{plq} / \mathrm{mL}$ (dot 6), sendo que $1,75 \times 10^{8} \mathrm{plq} / \mathrm{mL}$ (dot 3), seria a concentração ótima para o teste. Para os testes futuros, decidimos utilizar a concentração de $3 \times 10^{8}$ plq/mL, por ser a concentração mais próxima da fisiológica.

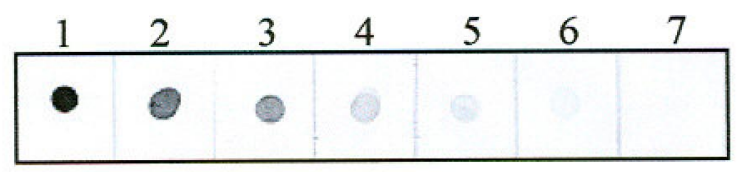

Fig. 47. Padronização da concentração de plaquetas. Dots de plaquetas foram adicionadas em membranas de nitrocelulose em concentrações decrescentes de plaquetas indo de $7 \times 10^{8}$ até $11 \times 10^{6}$. Estas foram incubadas por 1 hora a $37^{\circ} \mathrm{C}$ com $50 \mathrm{ng} / \mathrm{mL}$ de Er/APv e reveladas por $2 \mathrm{~min}$ com o substrato NBT/BCIP. 


\section{DISCUSSÃO:}

A clonagem e expressão de cDNAs exógenos em vetores de $E$. coli é uma estratégia amplamente difundida para a super-produção de proteínas heterólogas (Ducancel e col., 1989) ou fragmentos destas (Moura-da-Silva e col., 1999). Uma das dificuldades mais freqüentes no uso destes sistemas é que a conformação da maioria das proteínas de eucariontes depende de pontes dissulfeto que não podem ser formadas no ambiente redutor do citoplasma bacteriano (Hwang e col., 1992). Tal é o caso das disintegrinas que contèm entre 13 e $20 \%$ residuos de cisteínas. Para superar este empecilho, muitos vetores permitem a expressão de proteínas exógenas em fusão com proteínas que aumentam sua solubilidade no citoplasma, tal como é o caso da glutationa S-transferase (GST), produzida nos vetores pGEX (Smith and Johnson, 1988). Assim mesmo, proteínas de fusão como a tioredoxina impedem a formação de pontes dissulfeto no citoplasma, facilitando a solubilidade das proteinas recombinantes (Stewart e col., 1998). Outros sistemas abordam o problema de solubilidade sob uma perspectiva diferente, direcionando a expressão das proteinas exógenas ao periplasma. O periplasma, por sua vez não é um ambiente redutor e permite a formação de pontes dissulfeto (Uhlen e Moks, 1990). Nestes vetores as proteínas exógenas são geralmente clonadas após uma seqüência sinal que possibilita o direcionamento destas ao periplasma (Gillet e col., 1992). Neste trabalho, utilizamos estas duas abordagens no sentido de produzirmos fragmentos ricos em cisteínas, correspondentes a diferentes extensões dos domínios C-terminais da jararagina, a fim de correlacionarmos motivos estruturais da toxina com as funções da mesma.

A jararagina inibe a agregação plaquetária induzida por colágeno com um $\mathrm{IC}_{50}$ de 40 nM (Kamiguti e col., 1996). Além disso, inibe seletivamente a ligação de células $\alpha 2$ K562, expressando a integrina $\alpha 2 \beta 1$, ao colágeno (Moura da Silva e col,, 2001), confirmando assim a inibição da agregação plaquetária através do bloqueio desta integrina. Da mesma forma, a jararagina-C, produto de proteólise correspondente aos domínios ECDdisintegrina/rico-em-cisteínas, conserva atividade inibitória da agregação plaquetária (Usami e col., 1994). Além do mais, foi demonstrado que o produto análogo de Bothrops ahemaths, alternagina-C, inibe a adesão celular mediada pela integrina $\alpha 2 \beta 1$ (Souza e col., 2000). Estes dados e outros (Wang e col., 2002; Ito e col., 2001) sugerem que os motivos 
responsáveis pela inibição da agregação plaquetária se acham concentrados nos domínios ECD-disintegrina/rico-em-cisteínas. Bigler e colaboradores (2000), têm demonstrado que o dominio ECD-disintegrina da ADAM2, fertilina $\beta$, presente na membrana do espermatozóide é responsável pela ligação à integrina $\alpha 6 \beta 1$ do óvulo. Foi demonstrado que este domínio recombinante liga no óvulo e, além disso, inibe a ligação e fusão espermatozóide-óvulo. Por outro lado, Evans e colaboradores (1998), mostraram que o domínio rico-em-cisteinas recombinante desta mesma proteína também se liga ao óvulo. Além do mais, o domínio rico-em-cisteinas da atrolisina $\mathrm{A}$ inibe a agregação plaquetária. dependente de colágeno com um IC $\mathrm{C}_{50}$ de $456 \mathrm{nM}$ (Jia e col., 2000).

Trabalhos mais especificos mostram que o motivo de adesão se acha localizado no loop correspondente ao domínio ECD-disintegrina. O peptídeo sintético SECDPA, correspondente à região do loop do domínio disintegrina da jararagina conseguiu inibir a agregação plaquetária dependente de colágeno (Kamiguti e col., 1997). Zhou e colaboradores (1996), também conseguiram inibir esta atividade com um peptídeo cíclico contendo a sequuência SECDPA da Catrocolastatina-C. Do mesmo modo foi demonstrado que o peptídeo AQDECDVT correspondente à região do loop do domínio ECDdisintegrina da ADAM2 ế responsável pela ligação ao óvulo (Zhu e colaboradores, 2000). Entretanto, outros trabalhos indicam que outras regiões da molécula podem estar envolvidas nessa atividade. Recentemente, Kamiguti e colaboradores (2003), identificaram uma região no domínio rico-em-cisteínas da jararagina com atividade inibitória da agregação plaquetária dependente de colágeno. Ainda mais, Ivaska e colaboradores (1999), têm mostrado que o peptideo TRKKHDNAQ correspondente aos resíduos 241-249 do domínio catalítico da jararagina liga no domínio I da integrina $\alpha 2$.

Com a finalidade de caracterizar a regiăo da jararagina responsável por esta atividade produzimos 3 fragmentos correspondentes ao domínio ECD-disintegrina, 4 fragmentos correspondentes ao dominio rico-en-cisteinas e um oitavo fragmento, correspondente à jararagina-C, foi selecionado para expressar como controle positivo. A inibição da agregação plaquetária por parte da jararagina-C recombinante expressa no vetor pET-32 já foi demonstrada por Moura-da-Silva e colaboradores (1999). O teste de inibição da agregação plaquetária mostrou que nenhum dos fragmentos foi capaz de inibir esta 
atividade enquanto a jararagina inibiu completamente a agregação plaquetária Não conseguimos observar a ligaçào dos fragmentos nem ao colágeno nem às plaquetas. A ausência de atividade pode ser decorrente de uma baixa afinidade e por isto os fragmentos são deslocados quando adicionado o colágeno ou durante as lavagens nos ensaios de dot blot e ELISA. Outra possibilidade é que a região que compreende os fragmentos não seja suficientemente extensa para a interação com os receptores. Como explicado anteriormente, a jararagina é uma molécula que age integralmente nas suas funções. Podemos ver que os domínios ECD-disintegrina e rico-em-cisteínas de metaloproteinases de veneno inibem a agregação plaquetária com muita menos potência que a molécula inteira (Usami e col., 1994, De Luca e col, 1995).

Os fragmentos foram utilizados no teste em fusão com GST e não clivados, primeiro, porque sob nossa experiência, a porção GST tem se mostrado inerte, mantendo a atividade natural da disintegrina. A insularina, disintegrina do veneno de Bothrops insularis, apresentou-se biologicamente ativa, após ser expressa em fusão com GST, tanto na inibição da agregação plaquetária dependente de ADP, como na sua ligação a células expressando a integrina $\alpha v \beta 3$ (Della-Casa, tese de doutorado em andamento). Assim mesmo a rodostomina, disintegrina do veneno de Calloselasma rhodostoma foi expressa em fusão com GST, conservando sua atividade disintegrina (Chang e col., 1997). Segundo, nos testes de ligação por dot blot ou ELISA precisávamos de um marcador para verificar a capacidade de interação dos fragmentos com as plaquetas ou o colágeno. Neste caso, utilizamos a porção GST como marcadora, uma vez que o anticorpo policlonal anti-GST reconhece similarmente todos os fragmentos. O anticorpo policlonal anti-jararagina reagiu distintamente com os fragmentos como podemos ver na figura 14. O uso deste anticorpo nos testes de ligação impediria a comparação de um fragmento com outro tornando dificıl interpretar os resultados, além da possibilidade de interagir com epítopos envolvidos na atividade biológica, o que resultaria em competição no momento da detecção.

Mesmo considerando os pontos acima, nenhum dos fragmentos obtidos mostrou interatividade com $\alpha 2 \beta 1$ ou colágeno, sendo ineficientes em inibir a agregação plaquetária via colágeno. Com base nesses resultados, a região funcional da região ECDdisintegrina/rico-em-cisteínas da jararagina foi caracterizada de forma indireta através do anticorpo monoclonal MAJar3. Este anticorpo neutraliza as principais funções da 
jararagina: inibe a atividade hemorrágica da jararagina, sua ligação ao colágeno e a inibição da agregação plaquetária induzida por colágeno (Tanjoni e col., 2003). A reação do fragmento JD49 com o MAJar3 é muito interessante, uma vez que esta pequena região parece participar de diversas funçōes da jararagina. Harrison e colaboradores (2000), têm demonstrado que $o$ anticorpo policlonal anti-jararagina- $C$ consegue proteger camundongos da atividade hemorrágica da jararaģina. A participação da região correspondente a JD49 nesta atividade reforça estes dados e localiza o epítopo de interação na porção C-terminal do domínio ECD-disintegnna da jararagina Fica descartada uma alteração conformacional do dominio catalítico após ligação do MAJar3, uma vez que este anticorpo não conseguiu inibir a atividade proteolítica da jararagina em um substrato sintético fluorescente. Pelo fato do substrato corresponder a um peptídeo pequeno de 11 resíduos, este não teve nenhum impedimento para entrar na fenda catalítica (Tanjoni e col., 2003). A inibição da atividade hemorrágica provavelmente se deva a um bloqueio por parte do MAJar3 na ligação da jararagina com componentes da matriz extracelular como o colágeno. Nossos resultados sugerem que a porção correspondente a JD49 deva estar agindo como um exositio que serviria para direcionar a jararagina ao substrato a ser catalisado. Os exosítios são regiões extemas à região catalítica responsáveis pela ligação seletiva da enzima ao substrato aumentando a afinidade e muitas vezes preparando o substrato a ser clivado. Segundo dados de aditividade, o epítopo reconhecido pelo MAJar3 estaria muito próximo do domínio catalítico (Tanjoni e col, 2003) suportando a idéia de interação de ambas as regiões. A atividade colagenolítica de algumas MMPs têm sido relacionada com a presença de exosítios também. Na colagenase I, o domínio hemopexina C (exosítio) é fundamental para a atividade colagenolítica desta enzima. Após deletar este domínio se pode ver a extinção da colagenólise, no entanto, esta mantém sua atividade proteolitica em substrato sintético (Murphy e col., 1992). Assim mesmo, o domínio rico-em-cisteínas da ADAM 13 coopera intra-molecularmente com o domínjo catalítico modulando a atividade da protease in vivo (Smith e col., 2002).

Em um trabalho recente temos demonstrado que o anticorpo monoclonal, MAJarl, também reage só com o fragmento JD49 (Tanjoni e col., 2003). Este anticorpo inibe em $100 \%$ a atividade proteolítica e neutraliza parcialmente a hemorragia induzida pela jararagina. É interessante notar que o MAJarl reconhece um epitopo conformacional igual 
que o MAJar3 e testes de aditividade mostram que ambos os epitopos estão muito próximos. Estes dados sustentam a presença de uma região funcional na porção C-terminal do dominio ECD-disintegrina da jararagina e que esta região é dependente de conformação. Por outro lado não podemos sugerir o mesmo da porção $N$-terminal, já que os MAJares 2, 6 e 7 que reagem com esta região não têm atividade neutralizante (Tanjoni e col., 2003).

O MAJar3 reconhece um epitopo conformacional presente no fragmento JD49, já que em condições redutoras este anticorpo monoclonal não apresen tou reatividade (Tanjoni e col,, 2003). Esta regiăo é altamente conformacional e aparentemente não apresenta epítopos seqüenciais uma vez que a reatividade foi a mesma quando usamos o soro policlonal anti-jararagina. Cabe lembrar que as cisteínas 263 e a 279 , esta última correspondente ao ECD, formam pontes com cisteínas não inclusas no fragmento, razão pela qual a conformação do fragmento estaria comprometida. Podemos ver que a reatividade comn os fragmentos JD89 e JD98, onde a cisteína 263 está pareada, é bem mais intensa que com JD49, pelo que poderíamos sugenr que a formação dessa ponte é importante para a manutenção do epítopo reconhecido pelo MAJar3. Já no caso do JD98, que a diferença de JD89 permitiria a formação da ponte entre a cisteína do ECD (279) e a 299 , não vimos um aumento na intensidade do dot com respeito a JD89, pelo que podemos sugerir que a formação da ponte entre a cisteína 279 e a 299 não seria importante para a manutenção deste epítopo ou não estaria acontecendo no fragmento JD98. Resultados de dot blot com JD49/APv mostram que esta proteina de fusão não reage com o MAJar3 (dados não mostrados). A diferença do GST/JD49, no JD49/APv a extremidade C-terminal de JD49 não está livre e sim ligada com a fosfatase alcalina. Esta enzima deve estar mascaran do o epítopo reconhecido pelo MAJar3 que provavelmente se acha na região $\mathrm{C}$ terminal. Alérn do mais, trabalhos com RGD-disintegrinas mostram que a extremidade Cterminal é altamente funcional (Wierzbicka-Patynowski e col., 1999) o que sugere que anticorpos neutralizantes como o MAJar3 possam estar reconhecendo epítopos nesta região. Ainda mais, nossos resultados mostram que o epítopo estaria inteiramente localizado no fragmento, já que JD89, que é idêntico a JD49 na extremidade C-terminal, reage muito bem com o MAJar3. Destes dados podemos sugerir que o epítopo reconhecido pelo MAJar3 está totalmente incluído no JD49 e que se acha localizado no extremo Cterminal do fragmento. 
Aında não foi determinada qual seria a cisteína live, nem a importância desta permanecer reduzida ou oxidada. Se nos baseamos em comparações com RGDdisintegrinas, podemos sugerir que a cisteína do motivo ECD esteja livre. $\mathrm{O}$ alinhamento do dominio ECD-disintegrina da jararagina com a bitistatina (fig. 4) mostra todas as cisteinas conservadas exceto a cisteína do ECD. Assim mesmo, o modelo de W49, obtido a partir da estrutura da echistatina (fig. 18), mostra que a seqüência ECD está inserida em um loop e com a cisteína livre. Por outro lado, os resultados de Calvete e colaboradores (2000-B) e de Fujimura e colaboradores (2000), sugerem que a cisteina do ECD está envolvida na formação de uma ponte dissulfeto. No entanto, estes dados não são conclusivos, uma vez que foram verificados apenas para a catrocolastatina-C e p29K, fragmentos correspondentes apenas aos domínios ECD-disintegrina/rico-em-cisteínas. No mesmo trabalho, Fujimura e colaboradores (2000), observaram a presença de um grupo SH livre na brevilisina $\mathrm{H6}$, precursor de $\mathrm{p} 29 \mathrm{~K}$ apresentando os domínios catalítico, ECD-disintegrina e rico-em-cisteínas. Sendo assim, fica em aberto a possibilidade da cisteína do ECD estar tanto reduzida como oxidada. Se a cisteína do ECD estiver envolvida na formação de uma ponte S-S, o loop não poderia formar-se. No modelo da figura 18 podemos observar que a formação do loop dependeria da presença da cisteina do ECD reduzida. A formação da ponte implicaria na desestruturação do loop o que sugeriria um papel mais estrutural que funcional desta cisteína. A funcionalidade desta cisteína conservada também nas ADAMs, for estudada por mutagênese sitio-dirigida. No caso da fertilina $\beta$, a cisteina do ECD não parece ter importância funcional uma vez que sua substituição por uma alanina reduziu a lisgação a seu substrato só em $25 \%$ (Zhu e col., 2000). Mesmo que a jararagina não apresente um loop nesta região e a cisteína do ECD esteja envolvida em uma ponte dissulfeto, não podemos descartar funcionalidade à seqüência SECDPA como mostram os resultados de Kamiguti e colaboradores (1997) e Zhou e colaboradores (1996).

Nesta primeira parte do itabalho conseguimos correlacionar uma sequência mínima da jararagina, correspondente ao fragmento JD49, com grande parte da sua atividade biológica. Um estudo mais apurado dos motivos envolvidos nessas atividades poderá ocorrer através da caracterizaçăc do epítopo reconhecido pelo MAJar3. Isto será muito importante para entender a estrutura e função da jararagina e outras metaloproteinases, incluindo as ADAMs e MMPs. No entanto, não podemos deixar de olhar a jararagina como 
uın todo e lembrar que existem potenciais regiões já descritas no dominio catalitico (Ivaska e col., 1999) e rico-em-cisteinas (Kamiguti e col., 2003) que interfeririam com a ligação in tegrina $\alpha 2 \beta 1$-colágeno.

A segunda parte do trabalho corresponde ao desenvolvimento de marcadores moleculares baseados em disintegrinas em fusão com a fosfatase alcalina de $E$. coli. Esta enzima foi selecionada como marcadora uma vez que é altamente estável, já foi amplamente usada como ferramenta molecular (Lindbladh e col., 1993; Gillet e col., 1993; Chanussot e col, 1996) e os substratos de detecção estão comercialmente disponiveis. A fosfatase alcalina é um homodímero de $96 \mathrm{kDa}$, possuindo 2 pontes intramoleculares em cada monômero (Kim e Wyckoff, 1990). Estas pontes precisam ser formadas para que a enzima possa ficar conformacionalmente ativa (DuBose e Hartl, 1991) o que não ocorre quando a proteina é retida no citoplasma (Derman e Beckwith, 1991). Para conseguir tal conformação e atividade é necessário que a proteina seja secretada ao periplasma. Como a maioria das proteínas de secreção, o precursor contém uma seqüência sinal que é removida por una peptidase de sinal associada à membrana interna, pernitiodo a saída da proteína madura ao espaço periplásmico (Tnouye e Beckwith, 1977)

A utilização de disintegrinas como marcadores moleculares é uma nova abordagem para a detecção de integrinas. As disintegrinas ligam-se com altas afinidades nas integrinas $\left(\mathrm{Kd}, 10^{-7} \sim 10^{-8} \mathrm{M}\right)$, são de bajxo peso molecular $(\sim 5 \mathrm{kDa})$, apresentam uma estrutura filogeneticamente estável com um loop exposto de 14-17 $\AA$ (Adler e col., 1991; Saudek e col., 1991; Senn e Klaus, 1993), e muitas delas ligam-se às integrinas seletivamente. Muitos trabalhos têm mostrado a utilização de estruturas diferentes para a apresentação do loop com o motivo funcional RGD, gerando quimeras com atividade disintegrina (Lu e col., 1996; Vella e col, 2003). No entanto, nossos resultados mostram que a estrutura das disintegrinas recombinantes testadas é conformacionalmente estável o suficiente para apresentar atividade biológica preservada.

A eristostatina foi selecionada como base para a construção de marcadores moleculares devido a seu tamanho (49 resíduos), sua afinidade e seletividade pela integrina $\alpha \operatorname{llb} \beta 3$ de plaqueta. O fragmento JD49 também foi selecionado para ser usado como marcador. Uma vez que seria produzido no periplasma acreditávamos que poderia 
apresentar uma conformação cometa e por conseqüència atividade biológica. A expressão de JD49/APv e Er/APv for realizada com sucesso. Embora a porção disintegrina de ambas tivesse 8 cisteínas, as proteínas foram expressas com solubilidade no periplasma de $E$. coli. Os soros policlonais identificaram tanto as porções disintegrina como fosfatase alcalina na proténa bíbrida e o teste de atividade fosfatase alcalina mostrou que a inserção da disintegrina na região $N$-terminal da fosfatase alcalina não estava interferindo com a atividade biológica, sugerindo também que a porção disintegrina possa estar em uma conformação adequada estável e com atividade. Podemos ver no Westem blot, revelado diretamente com o substrato NBT/BCIP, que a intensidade das bandas de JD49/APv e Er/APv é proporcional às mesmas bandas no SDS-PAGE, sugerindo que a atividade fosfatase alcalina das disintegninas de fusão está diretamente relacionada com a quantidade de proteína. Ainda mais, mostramos que Er/APv tem atividade catalítica similar a APv. Isto sugere que toda a Er/APv exportada ao periplasma deve estar corretamente enovelada e com atividade biológica preservada. A formação das 4 pontes dissulfeto da porção erıstostatina não deve afetar o enovelamento da porção fosfatase alcalina, e ainda mais, não deve interferir com a formação do homodímero, essencial para estabilizar a estrutura da fosfatase alcalina (Martin e col., 1999)

No teste de Western blot, onde unlizamos o substrato NBT/BCIP para revelar as bandas com atividade fosfatase alcalina, mostrou-se que só e exclusivamente as proteinas recombinantes JD49/APv e Er/APv apresentaram atividade fosfatase alcalina entre as proteínas periplásmicas de $E$. coli. Estes dados foram muito importantes, uma vez que nos possibilitou trabalhar diretamente com o extrato periplásmico nos ensaios de adesão. Muller e colaboradores (1999) utilızaram também o extrato periplásmico, contendo a fração ScFv de um anticorpo monoclonal em fusão com a fosfatase alcalina de $E$. coli, na detecção direta do antígeno alvo.

O teste de inibição da agregação plaquetária é o ensaio tradicional para avalıar a atıvidade das RGD-disintegrinas. No entanto, durante os experimentos pudemos observar que o controle de fosfatase alcalina também estava inibindo esta atividade, o que tornaria impossivel determinar a inibição por parte da porção disintegrina. Com o objetivo de determinar se a inibição era decorrente da atividade catalitica da enzima ou de uma interação desta com as plaquetas, realizamos um teste de agregação utilızando fosfatase 
alcalina recombinante desprovida de atıvidade catalítica. Com esta enzima pudemos confirmar que a atividade enzimátıca é a responsável pela inibição da agregação plaquetária induzida por ADP e colágeno. Estes dados foram confirmados com os dados de dor blor onde mostramos a incapacidade de APv de se ligar às plaquetas. A fosfatase alcalina por ser uma fosfomonoesterase inespecifica deve desfosforilar o ADP, e dessa maneira, impedir a ação deste sobre as plaquetas. Isto impossibilitaria a determinação da inıbição da agregação plaquetária por parte da porçăo disintegrina. O ADP induz alterações conformacionais na plaqueta, por conseqüência a estrutura da integrina $\alpha \Pi b \beta 3$ muda de forma, permitindo a exposição de sítios de ligação (Marcinkiewicz e col., 1996), que levam à interação com o fibrinogênio, formando uma malha de plaquetas interligadas por este agonista (agregação plaquetária). No caso da agregação plaquetária induzida por colágeno, a fosfatase alcalina interfere também com esta atividade. Em condições naturais, o colágeno do subendotélio se liģa à integrina $\alpha 2 \beta 1$ desencadeando estímulos que levam à mudança de forma da plaçueta e à secreção de fatores dos grânulos (Murray e col., 1993). Para isto é preciso da fosforilação de ao menos duas proteinas: da cadeia leve da miosina (2l kDa) e da pleckstrina (47 kDa), envolvidas na mudança de forma da plaqueta e secreção, respectivamente (Kroll e Schafer, 1989). A presença da fosfatase alcalina no teste de agregação pode estar desfosforilando estas duas proteínas, inibindo assim a agregação plaquetária induzida por esta via.

O teste de adesão na forma de dol blot foi realizado como altemativa ao ensaio de agregação plaquetária. Neste teste, a proteína receptora pode ser aplicada diretamente na membrana sem ser submetida a tratamentos que possam implicar na sua desnaturação. Dessa forma, poderiamos testar o potencial das disintegrinas hibridas como ferramentas na deteç̧ão direta de seus receptores. Nossos resuitados mostram a praticidade deste sistema, já utilizado com êxito na detecção direta de 2-acetylaminofluorene-DNA (AAF-DNA) por parte do ScFv anti-AAF-DNA conjugado com a fosfatase alcalina (Muller e col., 1999). A porção eristostatina de Er/APv manteve sua atividade disintegrina, ligando-se fortemente com as plaquetas e com o PRP. No entanto, no caso das membranas tratadas com JD49/APv, não pudemos detectar ligação desta nem às plaquetas, nem ao PRP. Como esperado o controle negativo, APV, não se ligou a nenhum dos substratos utilizados 
Pensamos que o fato de JD49/APv não interagir com as plaquetas podia se dever a uma alteração conformacional, onde a sequência SECDPA correspondente ao suposto motivo adesivo (Kamiguti e col., 1997), não estaria exposta. A partiı do padrão das pontes dissulfeto da catrocollastatina-C (Calvete e col., 2000-B) podemos sugerir que JD49 esteja sem conformação natural preservada, já que 2 das 8 cisteínas estariam formando pontes com cisteinas não incluídas no fragmento Outra possibilidade seria que devido à integrina $\alpha 2 \beta 1$ se achar presente nas plaquetas em quantidades bem menores que a integrina $\alpha$ llb $\beta 3$, receptor da eristostatina (Hynes, 1991) os sitios de ligação para JD49/APr estariam em menor número. No entanto, esta proteína de fusão tambèm não se ligou às células $\alpha 2-\mathrm{K} 562$ que expressam a integrina $\alpha 2 \beta \mathrm{l}$, contrariamente a jararagina que liga tanto a estas células como às plaquetas. Para solucionarmos esta questăo optamos por inserir o loop de JD49 na estrutura da eristostatina, a qual está bem caracterizada e mantém suas 8 cisteinas envolvidas em 4 pontes dissulfeto (Calvete e col., 1994; McLane e col., 1996; Marcinkiewickz e col., 1996). Isto possibilitaria a estabilização do loop de JD49 e a exposição dos residuos centrais SECDPA, supostamente responsáveis pela inibição da agregação plaquetária dependente de colágeno (Kamiguti e col., 1997).

Inicialmente utilizamos a técnica do QuickChange site-directed mutagenesis kit (Stratagene), mas sem resultados positivos, uma vez que o número de mutações excedia o estipulado pelo fabricante. Como altemativa, optamos pelo método de megaprimer já usado com êxito na mutagênese sítio-dirigida da eristostatina e echistatina (WierzbickaPatynowski e col., 1999). Com respeito aos resultados da amplificação da quimera por PCR uthlizando o megaprimer C-ErECD3', podemos dizer que a fraca banda resultante deve-se à localização das mutações no megaprimer. As substituições do lado $3^{\circ}$ dos primers geralmente afetam as taxas de sintese de DNA (Nassal e Rieger, 1090). Outro fato importante para esta baixa amplificação pode ser o grande tamanho do primes: Quanto maior for o primer, menor é sua velocidade de anelamento com o template (Brown, 1996). Em nossos resul tados, podemos observar quando aumentamos o tempo de anelamento, que a intensidade da banda resultante aumentou.

A expressão de ECD-Er/APv foi similar à de Er/APv com uma concentração aproximada de $20 \mathrm{ng} / \mathrm{mL}$ e com atividade catalítica similar. Como mostrado nos resultados, 
nem JD49/APv nem a quimera ECD-Er/APv foram capazes de se ligar nem às plaquetas nem ás células $\alpha 2-K 562$. Este fato mostra por um lado que a regiăo do loop da eristostatina é fundamental para a ligação às plaquetas, já que sua substituição aboliu totalmente esta atividade. Por outro lado, parece que a seqüencia do loop contendo o motivo ECD não é suficiente para ligar com a integrina $\alpha 2 \beta 1$. Trabalhos com mutantes de disintegrinas mostram que os resíduos da porção terminal também são importantes para estabilizar a ligação com as integrinas (Wierzbicka-Patynowski e col, 1999). Outra possibilidade è que a seqüência SECDPA não esteja formando parte de um loop originalmente como já discutido acima Na construçăo ECD-Er/APv estamos forçando a exposição da seqüência SECDPA em um loop que não necessariamente corresponde com a conformação funcional do fragmento. A idéia que esta região está envolvida na formação de um loop se sustenta em bases teóricas e não em fatos experimentais. $\mathrm{O}$ alinhamento das ECD-disintegrinas com as RGD-disintegrinas e o modelo de JD49 obtido a partir da echistatina sugerem a formação do loop. A análise de qualidade do modelo mostra um único resíduo em uma região desfavorável, a senina 27. Este resíduo se encontra no loop e antecede ao ácido glutâmico do ECD No entanto, nosso modelo mostra a estrutura do loop muito flexível, o que pode justificar que a serina esteja em uma zona desfavorável. Porém, esta flexibilidade pode também justificar a adoção de uma outra conformação por parte dos resíduos SECDPA.

Por outro lado, a eristostatina mostrou-se ativa, preservando sua especificidade pela integrina $\alpha \Pi b \beta 3$. No teste de seletividade mostramos que $\mathrm{Er} / \mathrm{APv}$ se liga preferencialmente às células A5 que expressam a integrina $\alpha \Pi b \beta 3$, demonstrando a preservação da especificidade da porção eristostatina por esta integrina. Nos controles negativos podemos observar uma marcação tênue que provavelmente corresponde à fosfatase alcalina nativa destas células. É importante mencionar que muitas destas células expressam fosfatase alcalina na sua superficie (Burtis e Ashwood, 200l), dando falsos positivos na hora de revelar os dots com o substralo NBT/BCIP. Para confirmar o resultado de seletividade pela integrina $\alpha \Pi b \beta 3$, realizamos um teste de competição utilizando eristostatina recombinante ( $r-E r)$ sem fusão e com atividade biológica preservada. O ensaio mostrou que r-Er inibe a ligação de Er/APv às plaquetas, indicando que ambas as moléculas estariam ligando-se ao mesmo receptor (ou receptores) na plaqueta. 
Os dados de dot blot são conclusivos no que se refere à ligação de Er/APv às plaquetas. A padronização do teste de dot blot mostra que este é dose-dependente, sendo que mesmo quantias tão ínfimas de apenas $0,5 \mathrm{ng}$ de proteína por $\mathrm{mL}(\sim 10 \mathrm{pM})$ são capazes de ligar às plaquetas gerando um sinal ao ser reveladas com o substrato NBT/BCIP. Assim mesmo o teste também é tempo-dependente, mostrando um incremento da intensidade do dot com respeito ao tempo de incubação, sendo que com apenas 5 minutos de incubação pudemos revelar um dot positivo. Com respeito à temperatura de incubação obtivemos resultados similares tanto para 20 como para $37^{\circ} \mathrm{C}$. Assim mesmo, concentrações fisiológicas de plaquetas mostraram ser suficientes na reação.

A demonstração da afinidade e seletividade de Er/APv pela integrina $\alpha \Pi b \beta 3$ possibilita sua aplicação no diagnóstico de doenças dependentes da expressão desta integrina. A integrina $\alpha \Pi b \beta 3$ está envolvida principalmente na doença de Glanzmann, qüé consiste na ausência ou baixa expressão desta integrina nas plaquetas, levando a uma deficiência na agregação plaquetária e aumentando o período de sangramento do paciente (Newman e col., 1991). Esta integrina, até pouco conhecida nas plaquetas e seus precursores, foi recentemente descoberta em tumores de várias origens (Chen e col. 1997), apresentando aumento de expressão durante a metástase de células de adenocarcinoma da próstata (Trikha e col., 1998), também estando envolvida no arrest de células de melanoma em condições de fluxo (Felding-Habermann e col. 1996). A determinação da expressão da integrina $\alpha \Pi b \beta 3$ em cortes de tumores pode ser um ótimo indicador da progressão de um determinado tipo de câncer. Plaquetas tratadas com 3,7\% de formaldeido foram igualmente reativas com Er/APv a plaquetas não tratadas (dados não mostrados). Isto é muito importante, uma vez que os cortes histológicos são rotineiramente fixados com formaldeído $3,7 \%$ nos hospitais.

Este trabalho estabelece um ponto de partida para a construção de marcadores moleculares baseados em disintegrinas e sugere a utilização da estrutura destas para a apresentação e estudo de motivos funcionais de outras proteínas. Er/APv mostrou-se muito estável, conservando tanto sua atividade disintegrina como fosfatase alcalina até por uma ano após ser produzida. Além disso, verificamos que a liofilização de Er/APv não afetou em nada suas atividades comportando-se de igual maneira que a Er/APv recém preparada 
nos ensaios de dol blot. Partindo do rendimento da expressão/extração de Er/APv, podemos afirmar que com $50 \mathrm{~mL}$ de cultura inicial podemos realizar pelo menos 1000 detecções de dor blor. Adicionalmente, estes testes podem ser realizados a temperatura ambiente e sem necessidade de aparelhos sofisticados. Como podemos ver, a diferença dos anticorpos monoclonais, os marcadores baseados em disintegrinas são muito mais baratos, estáveis e simples de usar possibilitan do seu uso massificado pelo sistema de saúde pública, além de serem marcadores das regiões funcionais das integrinas, o que nem sempre ocorre com os demais reagentes. 


\section{CONCLUSÕES}

- Neste trabalho foi identificada uma regiăo na porção C-terminal do domínio ECDdisintegrina da jararagina com provável particıpação na ligação ao colágeno e atividade hemorágica.

- A eristostatina foi produzida com êxito em fusão com a fosfatase al calina resultando em uma proteina bifuncional com potencial uso como marcador molecular.

- Este trabalho serve de base para a produção de marcadores moleculares baseados em disintegrinas e a utilização da conformação destas para apresentar motivos exógenos. 


\section{REFERÊNCIAS BIBLIOGRÁFICAS:}

Adler M, Lazanus RA, Dennis MS, Wagner G. Solution structure of kistrin, a potent platelet aggregation inhibitor and GP Mb-Illa antagonist Science 1991 Jul $26 ; 253(5018): 445-8$.

Akiyama SK, Layava $H$, Yamada KM. Differences in the biosynthesis and localization of the fibronectin receptor in normal and transformed cultured human cells. Cancer Res 1990 Mar 1;50(5):1601-7.

Albelda SM, Buck CA. Integrins and other cell adhesion molecules. FASEB J 1990 Aug;4(11):2868-80.

Alberts B, Bray D, Lewis J, Raff M, Roberts K, Watson JD, (1994) Molecular Biology of the Cell. Third ed, (1994) Garland Publishing, New York.

Almeida EA, Huovila AP, Sutherland AE, Stephens LE, Calarco PG, Shaw LM, Mercurio AM, Sonnenberg A, Primakoff P, Myles DG, et al. Mouse egg integrin alpha 6 beta 1 functions as a sperm receptor. Cell 1995 Jun 30;81(7):1095-104.

Baramova EN, Shannon JD, Bjamason JB, Fox JW. Degradation of extracellular matrix proteins by hemorthagic metalloproteinases. Arch Biochem Biophys. 1989 Nov $15 ; 275(1): 63-71$

Baramova EN, Shannon JD, Bjamason JB, Fox JW. Identification of the cleavage sites by a hemorhagic metalloproteinase in type IV collagen. Matrix 1990 May;10(2):91-7.

Bello L, Lucini V, Carrabba G, Giussani C, Machluf M, Pluderi M, Nikas D, Zhang J, Tomei G, Villani RM, Cartoll RS, Bikfalvi A, Black PM Simultaneous inhibition of glıoma angrogenesis, cell proliferation, and invasion by a naturally occuring fragment of human metalloproteinase-2. Cancer Res 200I Dec 15;61 (24);8730-6.

Bessos H, Perez S, Armstong-Fisher S, Urbaniak S, Tumer M. The development of a quantitative ELISA for antibodies against human platelet antigen type la Transfusion 2003 Mar;43(3);350-6.

Bigler D, Takahashı Y, Chen MS, Almeida EA, Osbourne L, White M. Sequencespecific interaction between the disintegrin domain of mouse ADAM 2 (fertilin 
beta) and murine eggs. Role of the alpha(6) integrin subunit. J Biol Chem. $2000 \mathrm{Apr}$ $21,275(16): 11576-84$.

Bjarnason JB, Hamilton D, Fox JW. Studies on the mechanism of hemornage production by five proteolytic hemorthagic toxins from Crotalus atrox venom. Biol Chem Hoppe Seyler. 1988 May;369 Suppl:121-9.

Biamason JB, Fox JW. Hemorrhagic metalioproteinases from snake venoms. Pharmacol Ther 1994;62(3):325-72.

Biamason JB, Fox JW. Snake venom metalloendopeptidases: reprolysins. Methods Enzymol 1995;248:345-68

Black RA, Rauch CT, Kozlosky CJ, Peschon JJ, Slack JL, Wolfson MF, Castner BJ, Stocking KL, Reddy P, Srinivasan S, Nelson N, Boiani N, Schooley KA, Gerhart M, Davis R, Fitzmer JN, Johnson RS, Paxton RJ, March CJ, Cerretti DP. A metalloproteinase disintegrin that releases tumour-necrosis factor-alpha from cells Nature 1997 Feb 20;385(6618):729-33

Blakesley RW, Boezi JA. A new staining technique for protems in polyacrylamide gels using coomassie brilhant blue G250. Anal Bicchem. 1977 Oct,82(2):580-2.

Blobel CP, Wolfsberg TG, Turck CW, Myles DG, Primakoff P, White JM. A potential fusion peptide and an integrin ligand domain in a protein active in sperm-egg fusion. Nature 1992 Mar 19;356(6366) 248-52.

Blundell TL. Metalloproteinase superfamilies and drug design. Vat Struct Biol 1994 Feb;1(2):73-5.

Boehm $\Upsilon$, Folkman $\mathrm{I}$, Browder T, O'Reilly MS. Antiangiogenic therapy of experimental cancer does not induce acquired drug resistance. Nature 1997 Nov $27: 390(6658): 404-7$

Boer HA, Comstock LJ, Vasser $M$. The tac promoter: a functional hybnd derived from the trp and lac promoters. Proc Natl Acad Sci U S A. 1983 Jan;80(1):2 I-5. 
Brooks PC, Stromblad S, Klemke R, Visscher D, Sarkar FH, Cheresh DA. Antiintegrin alpha v beta 3 blocks human breast cancer growth and angiogenesis in human skin. J Clin Invest 1995 Oct;96(4):1815-22.

Brooks PC, Stromblad S, Sanders LC, von Schalscha TL, Aimes RT, Stetler-Stevenson WG, Quigley JP, Cheresh DA.Localization of matrix metalloproteinase MMP-2 to the surface of invasive cells by interaction with integrin alpha v beta 3. Cell 1996 May 31;85(5):683-93.

Brooks PC, Silletti S, von Schalscha TL, Friedlander M, Cheresh DA. Disruption of angiogenesis by PEX, a noncatalytic metalloproteinase fragment with integrin binding activity. Cell $1998 \mathrm{Feb}$ 6;92(3):391-400

Brown TA. Gene cloning, an introduction. Third edition, (1996) Chapman and Hall, London.

Buda A, Qualtrough D, Jepson MA, Martines D, Paraskeva C, Pignatelli M. Butyrate downregulates alpha2betal integrin: a possible role in the induction of apoptosis in colorectal cancer cell lines. Gut 2003 May;52(5):729-34.

Burridge K, Chrzanowska-Wodnicka M.Focal adhesions, contractility, and signaling. Annu Rev Cell Dev Biol 1996;12:463-518

Burtis CA, Ashwood ER, Tietz Fundamentals of Clinical Chemistry. Fifth edition, (2001) Saunders Company, Philadelphia, PA, p 366.

Calvete JJ. Clues for understanding the structure and function of a prototypic human integrin: the platelet glycoprotein IIb/Ila complex. Thromb Haemost 1994 Jul $; 72(1): 1-15$.

Calvete JJ, McLane MA, Stewart GJ, Niewiarowski S. Characterization of the crosslinking site of disintegrins albolabrin, bitistatin, echistatin, and eristostatin on isolated human platelet integrin GPIb/LUa. Biochem Bioplys Res Commun. 1994 Jul 15;202(1):135-40.

Calvete JJ, Jurgens M, Marcinkiewicz C, Romero A, Schrader M, Niewiarowski S. Disulphide-bond pattern and molecular modelling of the dimeric disintegrin EMF- 
10, a potent and selective untegrin alpha5betal antagonist from Eristocophus macmahoni venom. Biochem J 2000 Feb 1;345 Pt 3 573-81.

Calvete JJ, Moreno-Murciano MP, Sanz L, Jurgens M, Schrader M, Raida M, Benjamin DC, Fox JW. The disulfide bond pattern of catrocollastatin C, a disintegrinlike/cysteine-rich protein isolated from Crotalus atrox venom. Protein Sci. 2000 Jul;9(7):1365-73

Calvete JJ, Fox JW, Agelan A, Niewiarowski S, Marcinkiewicz C. The presence of the WGD motif in CC8 heterodimeric disintegrin increases its inhibitory effect on alphall(b)beta3, alpha(v)beta3, and alphasbetal integrins. Biochemistry 2002 Feb $12 ; 41(6): 2014-21$

Chan BM, Matsuura N, Takada Y, Zetter BR, Hemler ME. In vitro and in vivo consequences of VLA-2 expression on rhabdomyosarcoma cells. Science 1991 Mar $29 ; 251(5001): 1600-2$

Chang HH, Tsai WJ, Lo SJ. Glutathione S-transferase-rhodostomin fusion protein inhibits platelet aggregation and induces platelet shape change. Toxicon. 1997 Feb;35(2):195-204.

Chang JY. Thrombin specificity Requirement for apolar amino acids adjacent to the thrombin cleavage site of polypeptide substrate. Eur $J$ Biochem. 1985 Sep $2 ; 151(2): 217-24$.

Chanussot C, Bellanger L, Ligny-Lemaire C, Seguin P, Menez A, Boulain JC. Engineering of a recombinant colorimetric fusion protein for immunodiagnosis of insulin. J Immunol Methods. 1996 Oct 16;197(1-2):39-49.

Chen CS, Mrksich M, Huang S, Whitesides GM, Ingber DE. Geometric control of cell life and death. Science 1997 May 30;276(5317): 1425-8.

Chen FA, Repasky EA, Bankert RB. Human lung tumor-associated antigen identified as an extracellular matrix adhesion molecule. J Exp Med 1991 May 1;173(5):1111-9.

Chen P, Melchior C, Brons NH, Schlegel N, Caen J, Kieffer N. Probing conformational changes in the I-like domain and the cysteine-rich repeat of human beta 3 integrins following disulfide bond disruption by cysteine mutations: identification of cysteine 
598 involved in alphallbbeta3 activation. J Biol Chem 2001 Oct 19;276(42):3862835.

Chen YQ, Trikha M, Gao X, Bazaz R, Porter AT, Timar J, Honn KV. Ectopic expression of platelet integrin alphallb beta3 in tumor cells from various species and histological origin. Int J Cancer I997 Aug 7;72(4);642-8.

Cheresh DA. Structural and biologic properties of integrin-mediated cell adhesion. Clin Lab Med 1992 Jun;12(2):217-36.

Clissa PB, Laing GD, Theakston RD, Mota I, Taylor MJ, Moura-da-Silva AM. The effect of jararhagin, a metalloproteinase from Bothrops jararaca venom, on proinflammatory cytokines released by murine peritoneal adherent cells. Toxicon 2001 Oct;39(10):1567-73.

Correa MC Jr, Maria DA, Moura-da-Silva AM, Pizzocaro KF, Ruiz IR. Inhibition of melanoma cells tumorigenicity by the snake venom toxin jararhagin. Toxicon 2002 Jun;40(6):739-48.

Costa EP, Clissa PB, Teixeira CF, Moura-da-Silva AM. Importance of metalloproteinases and macrophages in viper snake envenomation-induced local inflammation. Inflammation 2002 Feb;26(1):13-7.

Cox D, Aoki T, Seki J, Motoyama Y, Yoshida K. The pharmacology of the integrins. Med Res Rev 1994 Mar;14(2):195-228.

Danen EH, van Mujjen GN, Ruiter DJ. Role of integrins as signal transducing cell adhesión molecules in human cutaneus melanoma. Em: Hart I, Hogg N, Eds. Cell Adhesion and Cancer. Cancer Surveys. Advances and Prospects in Clinical Epıdemiological and Laboratory Oncology. Plainview, NY: Cold Spring Harbor Laboratory Press, 1995, Vol 24 pp 43-65.

Danen EH, Marcinkiewicz C, Comelissen IM, van Kraats AA, Pachter JA, Ruiter DJ, Niewiarowski S, van Muijen GN. The disintegrin eristostatin interferes with integrin alpha 4 beta 1 function and with experimental metastasis of human melanoma cells. Exp Cell Res 1998 Jan 10;238(1):188-96. 
De Luca M, Ward CM, Ohmori K, Andrews RK, Berndt MC. Jararhagin and jaracetin: novel snake venom inhibitors of the integrin collagen receptor, alpha 2 beta $I$. Biochem Biophys Res Commun. 1995 Jan 17;206(2):570-6.

Dedhar S. Integrin mediated signal transduction in oncogenesis: an overview. Cancer Metastasis Rev 1995 Sep;14(3):165-72.

Derman AI, Beckwith J. Escherichia coli alkaline phosphatase fails to acquire disulfide bonds when retained in the cytoplasm. J Bacteriol. 1991 Dec;173(23):7719-22.

Deryugina EI, Bourdon MA, Luo GX, Reisfeld RA, Strongin A. Matrix metalloproteinase-2 activation modulates glioma cell migration. J Cell ScL 1997 Oct;110 ( Pt 19):2473-82.

Deryugina EI, Bourdon MA, Jungwirth $\mathrm{K}$, Smith JW, Strongin AY. Functional activation of integrin alpha $V$ beta 3 in tumor cells expressing membrane-type I matrix metalloproteinase. Int J Cancer 2000 Apr 1;86(1):15-23.

DuBose RF, Hartl DL. Evolutionary and structural constraints in the alkalıne phosphatase of E. coli Evolution at the molecular level (1991). Sinauer Associates, Sundeland, Mass.

Ducancel F, Boulain JC, Tremeau O, Menez A. Direct expression in E. coli of a functionally active protein A--snake toxin fusion protein. Protein Eng 1989 Nov;3(2):139-43

Duperray A, Troesch A, Berthier R, Chagnon E, Frachet P, Uzan G, Marguerie G. Biosynthesis and assembly of platelet GPIlb-Illa in human megakaryocytes: evidence that assembly between pro-GPMb and GPUla is a prerequisite for expression of the complex on the cell surface. Blood 1989 Oct; 74(5):1603-1 ]

Emsley J, Knight CG, Farndale RW, Bames MJ, Liddington RC. Structural basis of collagen recognition by integrin alpha2betal. Cell 2000 Mar $31 ; 101(1): 47-56$

Evans JP, Schultz RM. Kopf GS. Roles of the disintegrin domains of mouse fertilins alpha and beta in fertilization. Biol Reprod 1998 Jul;59(1):145-52 
Farrell DH, Thiagarajan P, Chung DW, Davie EW. Role of fibrinogen alpha and gamma chain sites in platelet aggregation Proc Natl Acad Sci U S A 1992 Nov 15;89(22):10729-32.

Felding-Habermann B, Habermann R, Saldivar E, Ruggeri ZM. Role of beta3 in tegrins in melanoma cell adhesion to activated platelets under flow. J Biol Chem 1996 Mar $8 ; 27 !(10) ; 5892-900$.

Fridman R, Fuerst TR, Bird RE, Hoyhtya M, Oelkuct M, Kraus S, Komarek D, Liotta LA, Berman ML, Stetler-Stevenson WG. Domain structure of human 72-kDa gelatinase/type IV collagenase. Characterization of proteolytic activity and identification of the tissue inhibitor of metalloproteinase-2 (TIMP-2) binding regions. J Biol Chem. 1992 Aug 5;267(22);15398-405.

Fujimura S, Oshikawa K, Terada S, Kimoto E. Primary structure and autoproteolysis of brevilysin $\mathrm{H} 6$ from the venom of Gloydius halys brevicaudus. J Biochem (Tokyo). 2000 Aug; 128(2):167-73

Gillet D, Ducancel F, Pradel E, Leonetti M, Menez A, Boulain JC. Insertion of a disulfide-containing neurotoxin into E. coli alkaline phosphatase: the hybrid retains both biological activities. Protein Eng. 1992 Apr,5(3):273-8.

Gillet D, Ezan E, Ducancel F, Gaillard C, Ardouin $\Upsilon$, Istin M, Menez A, Boulain IC, Grognet JM. Enzyme immunoassay using a rat prolactin-alkaline phosphatase recombinant tracer. Anal Chem. 1993 Jul 1;65(13): 1779-84.

Ginsberg MH, Loftus JC, Plow EF.Cytoadhesins, integrins, and platelets. Thromb Haemost 1988 Feb 25;59(1):1-6.

Gladson CL.Expression of integrin alpha $v$ beta 3 in small blood vessels of glioblastoma tumors. J Neuropathol Exp Neurol 1996 Nov;55(11):1143-9.

Gomis-Ruth FX, Kress LF, Bode W. First structure of a snake venom metalloproteinase' a prototype for matrix metalloproteinases/collagenases. EMBO J 1993 Nov; $12(11): 4151-7$. 
Gong W, Zhu X, Liu S, Teng M, Niu L. Crystal structures of acutolysin A, a threedisulfide hemorthagic zinc metalloproteinase from the snake venom of Agkistrodon acutus. J Mol Biol 1998 Oct 30;283(3):657-68.

Gould RJ, Polokoff MA, Friedman PA, Huang TF, Holt JC, Cook JJ, Niewarowski S Disintegrins: a family of integrin inhibitory proteins from viper venoms. Proc Soc Exp Biol Med 1990 Nov; 195(2):168-71.

Gui GP, Puddefoot JR, Vinson GP, Wells CA, Carpenter R. In vitro regulation of human breast cancer cell adhesion and invasion via integrin receptors to the extracellular matrix. BrJ Surg 1995 Sep;82(9):1 192-6.

Gutierrez JM, Romero M, Diaz C, Borkow G, Ovadia M. Isolation and characterization of a metalloproteinase with weak hemorhagic activity from the venom of the snake Bothrops asper (terciopelo). Toxicon 1995 Jan;33(1): 19-29.

Harrison RA, Moura-Da-Silva AM, Laing GD, Wu Y, Richards A, Broadhead A, Bianco $\mathrm{AE}$, Theakston RD. Antibody from mice immunized with DNA encoding the carboxyl-disintegrin and cysteine-rich doman (JD9) of the haemorthagic metalloprotease, Jararhagin, inhibits the main lethal component of viper venom. Clin Exp Immunol 2000 Aug; $121(2): 358-63$.

Heıno J Integrin-type extracellular matrix receptors in cancer and inflammation. Ann Med 1993 Aug;25(4):335-42.

Hite LA, Shannon JD, Bjarnason JB, Fox JW. Sequence of a cDNA clone encoding the zinc metalloproteinase hemorrhagic toxin e from Crotalus atrox: evidence for signal, zymogen, and disintegrin-like structures. Biochemustry $1992 \mathrm{Jul}$ 14;31(27):6203-11.

Ho PL, Serrano SM, Chudzinski-Tavassi AM, da Silva AM, Mentele R, Caldas C, Oliva ML, Batista Id Ide F, de Oliveira ML. Angiostat:-like molecules are generated by snake venom metalloproteinases. Biochem Biophys Res Commun 2002 Jun $21 ; 294(4): 879-85$. 
Hourihan RN, O'Sullivan GC, Morgan JG. Transcriptional gene expression profiles of oesophageal adenocarcinoma and normal oesophageal tissues. Anticancer Res 2003 Jan-Feb;23(1 A):161-5.

Huang TF, Wang WJ, Teng CM, Ouyang C.Mechanism of action of the antiplatelet peptide, arietin, from Bitis arietans venom. Biochim Biophys Acta 199l May $24 ; 3074(1): 144-50$.

Hughes PE, Pfaff M. Integrin affinity modulation. Trends Cell Biol 1998 Sep;8(9):35964.

Humphries MJ. Integrin structure. Biochem Soc Trans 2000;28(4):31 1 -39.

Flwang C, Sinskey AJ, Lodish $\mathrm{HF}$. Oxidized redox state of glutathione in the endoplasmic reticulum. Science. 1992 Sep 1 1;257(5076):1496-502.

Hymes RO The complexity of platelet adhesion to extracellular matrices. Thromb Haemost 1991 Jul 12;66(1):40-3

Hynes RO Integrins: versatility, modulation, and signaling in cell adhesion. Cell 1992 Apr 3:69(1): ll -25 .

Ingber DE, Prusty D, Frangioni NV, Cragoe EJ Jr, Lechene C, Schwartz MA. Control of intracellular $\mathrm{pH}$ and growth by fbronectin in capillary endothelial cells. J Cell Biol l990 May;110(5):1803-11.

Inouye $\mathrm{H}$, Beckwith J. Synthesis and processing of an Escherichia coli alkaline phosphatase precursor in vitro. Proc Natl Acad Sci U S A. 1977 Apr;74(4):1440-4

Ito M, Hamako J, Sakurai Y, Matsumoto M., Fujimura Y, Suzuki M, Hashimoto K, Titani $\mathrm{K}$, Matsui T. Complete amino acid sequence of kaouthiagin, a novel cobra venom metalloproteinase with two disintegrin-like sequences. Brochemistry. $2001 \mathrm{Apr}$ $10,40(14): 4503-11$

Ivaska J, Kapyla J, Pentikainen O, Hoffren AM, Hermonen J, Huttunen P, Johnson MS, Heino J. A peptide inhibiting the collagen binding function of integrin alphazI domain. J Biol Chem 1999 Feb 5;274(6):3513-21. 
Iwanaga S, Takeya $\mathrm{H}$. Structure and function of snake venom metalloproteinase family, in K. Imahori, F. Sakiyama (Eds.), Methods in Proteln Sequence Analysis, Plenum Press, NY, 1993, pp. 107-115.

Jia LG, Shimokawa K, Bjamason JB, Fox JW. Snake venom metalloprotennases: structure, function and relationship to the ADAMs family of protelns. Toxicon. 1996 Nov-Dec;34(11-12):1269-76.

Jia LG, Wang XM, Shannon JD, Bjamason JB, Fox JW. Inhibition of platelet aggregation by the recombinant cysteine-rich domain of the hemorrhagic snake venom metalloproteinase, atrolysin A. Arch Biochem Biophys. 2000 Jan 1;373(1):281-6

Juliano RL. The role of beta 1 integrins in tumors. Semin Cancer Biol 1993 Oct;4(5):27783

Kamiguti AS, Slupsky JR, Zuzel M, Hay CR. Properties of Gbrinogen cleaved by Jararhagin, a metalloproteinase from the venom of Bothrops jararaca. Thromb Haemost 1994 Aug; 72(2):244-9.

Kamiguti AS, Hay CR, Zuzel M. Inhibition of collagen-induced platelet aggregation as the result of cleavage of alpha 2 beta l-integrin by the snake venom metalloproteinase jararhagin. Biochem J 1996 Dec 1;320 ( Pt 2):635-4l.

Kamiguti AS, Moura-da-Silva AM, Laing GD, Knapp $T$, Zuzel M, Crampton JM, Theakston RD. Collagen-induced secretion-dependent phase of platelet aggregation is inhibited by the snake venom metalloproteinase jararhagin. Biochim Biophys Acta 1997 Apr 17;1335(1-2):209-17.

Kamiguti AS, Gallagher P, Marcinkievicz C, Theakston RD, Zuzel M, Fox JW. Identification of sites in the cysteine-rich domain of the class P-III snake venom metalloproteinases responsible for inhibition of platelet function. FEBS Lett. 2003 Aug 14;549(1-3):129-34

Kim EE, Wyckoff HW. Structure of alkaline phosphatases. Clin Chim Acta. 1990 Jan $15 ; 186(2): 175-87$ 
Kım JT, Lee do H, Chung KH, Kang IC, Kim DS, Joo CK. Inhibitory effects of salmosin, a disintegrin, on posterior capsular opacification in vitro and in vivo. Exp Eye Res 2002 May; 74(5):585-94.

Klein CE, Steinmayer T, Kaufinann D, Weber L, Brocker EB. Identification of a melanoma progression antigen as integrin VLA-2. J Invest Dermatol 1991 Feb;96(2):281-4.

Kloczewiak M, Timmons $\$$, Hawiger J.Recognition site for the platelet receptor is present on the 15-residue carboxy-terminal fragment of the gamma chain of human fibrinogen and is not involved in the fbrin polymerization reaction. Thromb Res $1983 \operatorname{Jan} 15 ; 29(2): 249-55$

Knight CG, Motton LF, Peachey AR, Tuckwell DS, Famdale RW, Bames MJ. The collagen-binding A-domains of integrins alpha(l)beta(1) and alpha(2)beta(1) recognize the same specific amino acid sequence, GFOGER, in native (triplehelical) collagens. J Biol Chem 2000 Jan 7;275(1);35-40.

Kroll MH, Schafer AI. Biochemical mechanisms of platelet activation. Blood. 1989 Sep; 74(4):1181-95

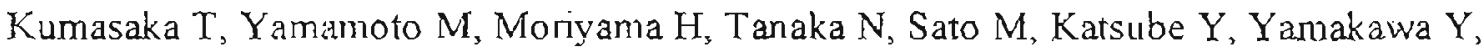
Omori-Satoh T, Iwanaga S, Ueki T. Crystal structure of H2-proteinase from the venom of Trimeresunus flavoviridis. J Biochem (Tokyo) $1996 \mathrm{Jan} ; 119(1$ ):49-57.

Laemmli UK Cleavage of structural proteins during the assembly of the head of bacteriophage T4 Nature. 1970 Aug 15;227(259):680-5.

Lefkovits J, Plow EF, Topol EJ. Platelet glycoprotein Ub/Tla receptors in cardiovascular medicine. N Engl J Med 1995 Jun 8;332(23):1553-9.

Leytin V, Shapiro H, Novikov I, Radnay J.Flow cytometric analysis of the platelet surface area and surface density of glycoprotein Mb-Mla of unactivated human platelets of various sizes. Biochem Biophys Res Commun 1996 Sep 4;226(1):94-100.

Liapıs H, Adler LM, Wick MR, Rader JS.Expression of alpha(v)beta3 integrin is less frequent in ovarian epithelial tumors of low malignant potential in contrast to ovarian carcinomas. Hum Pathol 1997 Apr;28(4):443-9. 
Lindbladh C, Mosbach K, Bulow L. Use of genetically prepared enzyme conjugates in enzyme immunoassay. Trends Biochem Sci. 1993 Aug, 18(8):279-83.

Liu Z, Brattain MG, Appert H. Differential display of reticulocalbin in the highly invasive cell line, MDA-MB-435, versus the poorly invasive cell line, MCF-7. Biochem Biophys Res Commun 1997 Feb 13;231(2):283-9

Loechel F, Gilpin BJ, Engvall E, Albrechtsen R, Wewer UM. Human ADAM 12 (meltrin alpha) is an active metalloprotease. J Biol Chem 1998 Jul 3;273(27):16993-7.

Lu X, Rahman S, Kakkar VV, Authi KS. Substitutions of proline 42 to alanme and methionine 46 to asparagine around the RGD domain of the neurotoxin dendroaspin alter its preferential antagonism to that resembling the disintegtin elegantin. J Biol Chem 1996 Jan 5;271(1):289-94

Marcinkiewicz C, Rosenthal LA, Mosser DM, Kunicki TJ, Niewiarowski S. Immunological characterization of eristostatin and echistatin binding sites on alpha IIb beta 3 and alpha V beta 3 integrins. Biochem J. 1996 Aug 1;317 ( Pt 3):817-25.

Marcinkiewicz C, Calvete JJ, Marcinkiewicz MM, Raida M, Vijay-Kumar S, Huang Z, Lobb RR, Niewiarowski S. EC3, a novel heterodimeric disintegrin from Echis cannatus venom, inhibits alpha4 and alphas integrins in an RGD-independent manner. J Biol Chem 1999 Apr 30;274(18):12468-73.

Marcinkiewicz C, Calvete JJ, Vijay-Kumar S, Marcinkiewicz MM, Raida M, Schick P, Lobb RR, Niewiarowski S. Structural and functional characterization of EMF10, a heterodimeric disintegrin from Eristocophis macmahoni venom that selectively inhibits alpha 5 beta 1 integrin. Biochemistry 1999 Oct 5;38(40):13302-9.

Marcinkiewicz C, Taooka Y, Yokosaki Y, Calvete JJ, Marcinkiewicz MMM, Lobb RR, Niewiarowski S, Sheppard D. Inhibitory effects of MLDG-containing heterodimeric disintegrins reveal distinct structural requirements for interaction of the integrin alpha 9beta I with VCAM-l, tenascin-C, and osteopontin. I Biol Chem 2000 Oct $13 ; 275(41): 31930-7$

Markland FS. Snake venoms and the hemostatic system. Toxicon 1998 Dec;36(12): 1749 800. 
Martin DC, Pastra-Landis SC, Kantrowitz ER. Amino acid substitutions at the subunit interface of dimeric Escherichia coli alkaline phosphatase cause reduced structural stability. Protein Sci. 1999 May;8(5):11 52-9.

Maruyama M, Sugiki M, Yoshida E, Shimaya K, Mihara H. Broad substrate specificity of snake venom fibrinolytic enzymes: possible role in haemorrhage. Toxicon. 1992 Nov;30(11):1387-97.

Mashiko $\mathrm{H}$, Takahashi $\mathrm{H}$. Haemorrhagic factors from snake venoms. Structures of haemorhagic factors and types and mechanisms of haemorrhage. J. Toxicol. Toxin Rev 1998 (17) 493-512.

McKay DG, Moroz C, De Vries A, Csavossy I, Cruse V. The action of hemorrhagin and phospholipase derived from Vipera palestinae venom on the microcirculation. Lab Invest 1970 May;22(5):387-99.

McLane MA, Kowalska MA, Silver L, Shattil SJ, Niewiarowski S. Interaction of disintegrins with the alpha $\mathrm{Ib}$ beta 3 receptor on resting and activated human platelets. Biochem J 1994 Jul 15;301 (Pt 2):429-36.

McLane MA, Vijay-Kumar S, Marcinkiewicz C, Calvete JJ, Niewrarowski S. Importance of the structure of the RGD-containing loop in the disintegrins echistatin and eristostatin for recognition of alpha Ilb beta 3 and alpha $v$ beta 3 integrins. FEBS Lett 1996 Aug 5;391(1-2):139-43.

McLane MA, Marcinkiewicz C, Vijay-Kumar S, Wierzbicka-Patynowski I, Niewiarowski S. Viper venom disintegrins and related molecules. Proc Soc Exp Biol Med 1998 Nov;219(2):109-19.

McLane MA, Kuchar MA, Brando C, Santoli D, Paquette-Straub CA, Miele ME. New insights on disintegrin-receptor interactions. enstostatin and melanoma cells. Haemostasis 2001 May-Dec;3 1 (3-6): 177-82.

Millichip MT, Dallas DJ, Wu E, Dale S, McKie N. The metallo-disintegrin ADAM10 (MADM) from bovine kidney has type IV collagenase activity in vito. Biochem Biophys Res Commun 1998 Apr 17;245(2):594-8 
Mizejewskj GJ.Role of integrins in cancer: survey of expression patterns. Proc Soc Exp Biol Med 1999 Nov;222(2):124-38

Moreira L, Borkow G, Ovadia M, Gutierrez JM. Pathological changes induced by BaHl, a hemorthagic proteinase isolated from Bothrops asper (Terciopelo) snake venom, on mouse capillary blood vessels. Toxicon 1994 Aug;32(8):976-87.

Moreno-Murciano MP, Monleon D, Calvete JJ, Celda B, Marcinkıewicz C. Amino acid sequence and homology modeling of obtustatin, a novel non-RGD-containing short disintegrin isolated from the venom of Vipera lebetina obtusa. Protein Sci 2003 Feb;12(2):366-7l

Morris VL, Schmidt EE, Koop S, MacDonald IC, Grattan M, Khokha R, McLane MA, Niewiarowski S, Chambers AF, Groom AC. Effects of the disintegrin eristostatin on individual steps of hematogenous metastasis. Exp Cell Res 1995 Aug;219(2):571-8.

Moura-da-Silva AM, Laing GD, Paine MJ, Dennison JM, Politi V, Crampton JM, Theakston RD. Processing of pro-tumor necrosis factor-alpha by venom metalloproteinases a hypothesis explaining local tissue damage following snake bite. Eur J Immunol 1996 Sep;26(9):2000-5.

Moura-da-Silva AM, Linica A, Della-Casa MS, Kamiguti AS, Ho PL, Crampton JM, Theakston RD. Jararhagin ECD-containing disıntegrin domain: expression in escherichia coli and inhibition of the platelet-collagen interaction. Arch Biochem Biophys. 1999 Sep 15;369(2):295-301.

Moura-da-Silva AM, Marcinkiewicz C, Marcinkiewicz M, Niewiarowski S. Selective recognition of alphazbetal integrin by jararhagin, a Metalloproteinase/disintegrin from bBothrops jararaca venom. Thromb Res. 2001 Apr 15;102(2):153-9.

Moura-da-Silva AM, Della-Casa MS, David AS, Assakura MT, Butera D, Lebrun I, Shannon JD, Serrano SM, Fox JW. Evidence for heterogeneous forms of the snake venom metalloproteinase jararhagin: a factor contributing to snake venom variability. Arch Biochem Biophys 2003 Jan 15;409(2):395-401. 
Muller BH, Chevrier D, Boulain JC, Guesdon J. Recombinant single-chain Fv antibody fragment-alkaline phosphatase conjugate for one-step immunodetection in molecular hybridization. J Immunol Methods. 1999 Jul 30;227(1-2):177-85

Murphy G, Allan JA, Willerbrock F, Cockett MI, O'Connell JP, Docherty AJ. The role of the $\mathrm{C}$-terminal domain in collagenase and stromelysin specificity. I Biol Chem. 1992 May 15;267(14):9612-8

Murray RK, Granner DK, Mayes PA, Rodwell VW. Harper's Biochemistry. Ed. (1993) 23, Appleton \& Lange, Norwalk, CT.

Nakamura $Y$, Gojobori T, Ikemura T. Codon usage tabulated from the intemational DNA sequence databases. Nucleic Acids Res. 1998 Jan 1;26(1):334.

Nassal M, Rieger A. PCR-based site-durected mutagenesis using primers with mismatched 3'-ends. Nucleic Acids Res. 1990 May 25;18(10):3077-8.

Natali PG, Nicotra MR, Botti C, Mottolese M, Bigotti A, Segatto O. Changes in expression of alpha 6/beta 4 integrin heterodimer in primary and metastatic breast cancer. Br J Cancer 1992 Aug;66(2):318-22.

Newman PJ, Seligsohn U, Lyman S, Coller BS. The molecular genetic basis of Glanzmann thrombasthenia in the Iraqi-Jewish and Arab populations in Israel. Proc Natl Acad Sci U S A 1991 Apr 15;88(8):3160-4.

Nurden AT, Caen JP.An abnomal platelet glycoprotein pattem in three cases of Glanzmann's thrombasthenia. Br J Haematol 1974 Oct;28(2):253-60.

Osaka A, Just M, Habermann E. Action of snake venom hemorrhagic principles on isolated glomerular basement membrane. Biochim Biophys Acta 1973 Oct $25 ; 323(3): 415-28$

Ownby CL, Bjarnason $J$, Tu AT. Hemorrhagic toxins from rattlesnake (Crotalus atrox) venom. Pathogenesis of hemorhage induced by three purified toxins. Am J Pathol 1978 Oct;93(1):201-18.

Paine MJ, Desmond HP, Theakston RD, Crampton JM. Purification, cloning, and molecular characterization of a high molecular weight hemorrhagic metalloprotease, 
jararhagin, from Bothrops jararaca venom. Insights into the disintegrin gene family. J Biol Chem. 1992 Nov 15;267(32):22869-76.

Phillips DR, Charo IF, Parise LV, Fitzgerald LA. The platelet membrane glycoprotein Пb-Шl complex. Blood 1988 Apr;71(4):831-43.

Phillips DR, Scarborough RM. Clinical pharmacology of eptifibatide. Am J Cardiol 1997 Aug 18;80(4A): 11B-20B.

Pierschbacher $\mathrm{MD}$, Ruoslahti E. Cell attachment activity of fibronectin can be duplicated by small synthetic fragments of the molecule. Nature 1984 May 3-9;309(5963) 303.

Plantefaber LC, Hynes RO. Changes in integnin receptors on oncogenically transformed cells. Cell 1989 Jan 27;56(2):281-90.

Plow EF, Ginsberg MH. Specific and saturable binding of plasma fibronectin to thrombin-stimulated buman platelets. J Biol Chem 1981 Sep 25;256(18):9477-82.

Plow EF, Srouji AH, Meyer D, Marguene G, Ginsberg MH. Evidence that three adhesive proteins interact with a common recognition site on activated platelets. J Biol Chem 1984 May 10;259(9):5388-91.

Plow EF, McEver RP, Coller BS, Woods VL Jr, Marguerie GA, Ginsberg MH.Related binding mechanisms for fibrinogen, fibronectin, von Willebrand factor, and thrombospondin on thrombin-stimulated human platelets. Blood 1985 Sep;66(3):724-7.

Plow EF, D'Souza SE, Ginsberg MH. Ligand binding to GPDb-Mla: a status report. Semin Thromb Hemost 1992;18(3):324-32.

Rucavado A, Lomonte B, Ovadia M, Gutienez JM. Local tissue damage induced by $\mathrm{BaPl}$, a metalloproteinase isolated from Bothrops asper (Terciopelo) snake venom. Exp Mol Pathol. 1995 Dec;63(3):186 99.

Rucavado A, Flores-Sanchez E, Franceschi A, Magalhaes As Gutierrez JM. Characterization of the local tissue damage induced by LHE-II, a metalloproteinase 
with weak hemorrhagic activity isolated from Lachesis muta muta snake venom. Toxicon. 1999 Sep;37(9):1297-312.

Rudolph R, Chereshi D.Cell adhesion mechanisms and their potential impact on wound healing and tumor control. Chn Plast Surg $1990 \mathrm{Jul} ; 17(3): 457.62$.

Ruoslahti E, Pierschbacher MD. Arg-Gly-Asp: a versatile cell recognition signal. Cell 1986 Feb 28;44(4):517-8.

Ruoslahti E. The Walter Herbert Lecture. Control of cell motility and tumour invasion by extracellular matrix interactions. Br J Cancer 1992 Aug;66(2):239-42.

Saelman EU, Nieuwenhuis HK, Hese KM, de Groot PG, Heijnen HF, Sage EH, Williams S, McKeown L, Gralnick HR, Sixma JJ. Platelet adhesion to collagen types I through VIII under conditions of stasis and flow is mediated by GPIa/lla (alpha 2 beta l-integrin). Blood 1994 Mar 1;83(5):1244-50.

Sambrook J, Fntsch EF, Maniatis, Molecular Cloning a laboratory manual. Second ed. (1989) Cold Spring Harbour Laboratory, Press. New York.

Sanger F, Nicklen S, Coulson AR. DNA sequencing with chain-terminating inhibitors. 1977. Brotechnology. 1992;24 104-8

Saudek V, Atkinson RA, Pelton JT. Three-dimensional structure of echistatin, the smallest active RGD protein. Biochemistry 1991 Jul 30;30(30):7369-72.

Senger DR, Claffey KP, Benes JE, Pertuzzi CA, Sergiou AP, Detmar M. Ang1ogenesis promoted by vascular endothelial growth factor: regulation through alphalbetal and alpha2betal integrins. Proc Natl Acad Sci U S A 1997 Dec 9;94(25):13612-7.

Senn $\mathrm{H}, \mathrm{KJ}$ aus $\mathrm{W}$. The nuclear magnetic resonance solution structure of flavoridin, an antagonist of the platelet GP llb-Пla receptor. J Mol Biol 1993 Aug 5;232(3):90725.

Sheu JB, Ko WC, Hung WC, Peng HC, Huang TF. Interaction of thrombin-activated platelets with extracellular matrices (fibronectir and vitronectin): comparison of the activity of Arg-Gly-Asp-containing venom peptides and monoclonal antibodies against glycoprotein Mb/Mla complex. J Pharm Pharmacol 1997 Jan;49(1):78-84. 
Sheu JR, Yen MH, Peng HC, Chang MC, Huang TF. Triflavin, an Arg-Gly-Aspcontaining peptide, prevents platelet plug formation in in vivo experiments. Eur $J$ Pharmacol 1995 Dec 27;294(1):231-8.

Silletti $S$, Kessler $T$, Goldberg J, Boger DL, Cheresh DA. Disruption of matrix metalloproteinase 2 binding to integrin alpha vbeta 3 by an organic molecule inhibits angiogenesis and tumor growth in vivo. Proc Natl Acad Sci U S A 2001 Jan 2;98(1):1 19-24

Simons PC, Vander Jagt DL. Purification of glutathione S-transferases from human liver by glutathione-affioity chromatography. Anal Biochem. 1977 Oct;82(2):334-41.

Smith DB, Johnson KS. Single-step purification of polypeptides expressed in Escherichia coli as fusions with glutathione S-transferase. Gene. 1988 Jul 1 5;67(1):3 1-40.

Smith KM, Gaultier A, Cousin H, Alfandari D, White JM, DeSimone DW. The cysteinerich domain regulates $\mathrm{ADAM}$ protease function in vivo. J Cell Biol $2002 \mathrm{Dec}$ $9 ; 159(5): 893-902$.

Souza DH, Iemma MR, Ferreira LL, Fania JP, Oliva ML, Zingali RB, Niewiarowski S, Selistre-de-Araujo HS. The disintegrin-like domain of the snake venom metalloprotease altemagin inhibits alpha2betal integrin-mediated cell adhesion. Arch Biochem Biophys. 2000 Dec 15;384(2):341-50.

Stewart EJ, Aslund F, Beckwith J.Disulfide bond formation in the Escherichia coli cytoplasm: an in vivo role reversal for the thioredoxins. EMBO J. 1998 Oct $1 ; 17(19): 5543-50$.

Stocker W, Grams F, Baumann U, Reinemer P, Gomis-Ruth FX, McKay DB, Bode W. The metzincins-topological and sequential relations between the astacins, adamalysins, sersalysins, and matrixins (collagenases) define a superfamily of zincpeptidases. Protein Sci 1995 May;4(5):823-40

Takeya H, Oda K, Miyata T, Omori-Satoh T, Iwanaga S. The complete amino acid sequence of the high molecular mass hemorthagic protein HRIB isalated from the venom of Trimeresurus favoviridis. J Biol Chem 1990 Sep 25;265(27):16068-73. 
Takeya H, Nishida S, Miyata T, Kawada S, Saisaka Y, Morita T, Iwanaga S. Coagulation factor $X$ activating enzyme from Russell's viper venom (RVV-X). A novel metalloproteinase with disintegrin (platelet aggregation inhibitor)-like and C-type lectin-like domains. J Biol Chem. 1992 Jul 15;267(20):14109-17.

Takeya H, Miyata T, Nishino N, Omori-Satoh T, Iwanaga S. Snake venom hemorrhagic and nonhemorrhagic metalloendopeptidases. Methods Enzymol 1993:223:365-78.

Tanjoni I, Butera D, Bento L, Della-Casa M, Marques-Porto R, Takehara H, Gutierrez JM, Fernandes L, Moura-da-Silva AM. Snake Venom Metalloproteinases: Structure/function relationships studies using monoclonal antibodies. Toxicon 2003; 42(7): $80 \mathrm{l}-808$

Topol EJ, Byzova TV, Plow EF. Platelet GPIJb-IIIa blockers, Lancet 1999 Jan $16 ; 353(9148): 227-31$.

Tortorella MD, Pratta MA, Fox NW, Amer EC. The interglobular domain of cartilage aggrecan is cleaved by hemornhagic metalloproteinase HT-d (atrolysin C) at the matrix metalloproteinase and aggrecanase sites. J Biol Chem 1998 Mar $6 ; 273(10): 5846-50$

Tortorella MD, Burn TC, Pratta MA, Abbaszade I, Hollis JM, Liu R, Rosenfeld SA, Copeland RA, Decicco CP, Wynn R, Rockwell A, Yang F, Duke JL, Solomon K, George H, Bruckner R, Nagase H, Itoh Y, Ellis DM, Ross H, Wiswall BH, Murphy $\mathrm{K}$, Hillman MC Jr, Hollis GF, Amer EC, et al. Purification and cloning of aggrecanase-l: a member of the ADAMTS family of proteins. Science 1999 Jun $4 ; 284(5420) \cdot 1664-6$.

Towbin H, Staehelin T, Gordon J. Electrophoretic transfer of proteins from polyacrylamide gels to nitrocellulose sheets: procedure and some applications. 1979. Biotechnology. 1992;24:145-9.

Trikha M, Raso E, Cai Y, Fazakas Z, Paku S, Porter AT, Timar J, Honn KV.Role of alphall(b)beta3 integrin in prostate cancer metastasis. Prostate 1998 May $15 ; 35(3): 185-92$. 
Uhlen M, Moks $\Upsilon$. Gene fusions for purpose of expression: an introduction. Methods Enzymol. 1990;185'129-43.

Usami Y, Fujimura Y, Miura S, Shima H, Yoshida E, Yoshioka A, Hirano K, Suzuki M, Titani K. A $28 \mathrm{kDa}$-protein with disintegrin-like structure (jararhagin-C) purified from Bothrops jararaca venom inhibits collagen- and ADP-induced platelet aggregation. Biochem Biophys Res Commun. 1994 May 30;201(1):33 1-9

Varner JA, Cheresh DA. Integrins and cancer. Curr Opin Cell Biol 1996 Oct;8(5):724-30.

Vella F, Thielens NM, Bersch B, Arlaud GJ, Frachet P. A recombinant chimeric epidermal growth factor-like module with high binding affinity for integrins. J Biol Chem. 2003 May 30;278(22):19834-43. Epub 2003 Mar 24.

Virtanen I, Korhonen M, Kariniemi AL, Gould VE, Laitinen L, Ylanne J. Integrios in human cells and tumors. Cell Differ Dev 1990 Dec 2;32(3):215-27.

Voest EE. Inhibitors of angiogenesis in a clinical perspective. Anticancer Drugs 1996 Sep;7(7):723-7.

Wagner CL, Mascelli MA, Neblock DS, Weisman HF, Coller BS, Jordan RE. Analysis of GPIIb/IIla receptor number by quantification of 7E3 binding to human platelets. Blood 1996 Aug 1;88(3):907-14.

Wang WJ, Huang TE. Purification and characterization of a novel metalloproteinase, acurhagin, from Agkistrodon acutus venom. Thromb Haemost. 2002 Apr;87(4):64 I50 .

Wierzbicka-Patynowski I, Niewiarowski S, Marcinkiewicz C, Calvete J\}, Marcinkiewicz MD, Mclane MA. Structural requirements of echistatin for the recognition of alpha(v)beta(3) and alpha(5)beta(1) integrins. J Biol Chem 1999 Dec $31 ; 274(53): 37809-14$.

Willenbrock F, Crabbe 'T, Slocombe PM, Sutton CW, Docherty AJ, Cockett Ma, O'Shea M, Brocklehurst K, Phillps IR, Murphy G. The activity of the tissue inhibitors of metalloproteinases is regulated by $\mathrm{C}$-terminal domain interactions: a kinetic analysis of the inhibition of gelatinase A. Biochemistry 1993 Apr 27;32(16):4330-7. 
Willis TW, Tu AT. Purification and brochemical characterization of atroxase, a nonhemorrhagic fibrinolytic protease from western diamondback rattlesnake venom. Biochemistry 1988 Jun 28;27(13):4769-77

Wolfsberg TG, Bazan JF, Blobel CP, Myles DG, Primakoff P, White JM. The precursor region of a protein active in sperm-egg fusion contains a metalloprotease and a disintegrin domain: structural, functional, and evolutionary implications. Proc Nat! Acad Sci U S A 1993 Nov 15,90(22) 10783-7.

Wolfsberg TG, White JM. ADAMs in fertilization and development. Dev Biol 1996 Dec $15 ; 180(2) .389-401$.

Xiong J, Stehle T, Zhang R, Joachimiak A, Frech M, Goodman SL, Amaout MA. Crystal structure of the extracellular segment of integrin alpha Vbeta 3 in complex with an Arg-Gly-Asp ligand. Science 2002 Apr 5;296(5565):151-5.

Yeh $\mathrm{CH}$, Peng HC, Yang RS, Huang TF. Rhodostomin, a snake venom disintegrin, inhibits angiogenesis elicited by basic fibroblast growth factor and suppresses tumor growth by a selective alpha(v)beta(3) blockade of endothelial cells. Mol Pharmacol 2001 May;59(5):1333-42.

Zhang D, Botos L, Gomis-Ruth FX, Doll R, Blood C, Njoroge FG, Fox JW, Bode W, Meyer EF. Structural interaction of natural and synthetic inhibitors with the venom metalloproteinase, atrolysin C (fom d). Proc Natl Acad Sc U S A 1994 Aug $30 ; 91(18): 8447-51$

Zhou Q, Smith JB, Grossman MH. Molecular cloning and expression of catrocollastatin, a snake-venom protein from Crotalus atrox (western diamondback rattlesnake) which inhibits platelet adhesion to collagen. Biochem J 1995 Apr 15;307 ( Pt 2):41 I -7.

Zhou Q, Dangelmaier C, Smith JB. The hemorrhagin catrocollastatin inhibits collageninduced platelet aggregation by binding to collagen via its disintegrin-like domain Biochem Biophys Res Commun 1996 Feb 27;219(3).720-6.

Zhou Q, Sherwin RP, Parrish C, Richters V, Groshen SG, Tsao-Wei D, Markland FS. Contorttostatin, a dimeric disintegrin from Agkistrodon contortrix contortrix, inhibits breast cancer progression. Breast Cancer Res Treat 2000 Jun;61 (3):249-60. 
Zhu X, Bansal NP, Evans JP. Identification of key functional amino acids of the mouse fertilin beta (ADAM2) disintegrin loop for cell-cell adhesion during fertilization. J Biol Chem. 2000 Mar 17;275(11):7677-83. 


\section{CURRICULUM VITAE}

NOME: Diego Alberto Butera Wadsworth

LOCAL E DATA DE NASCIMENTO: Sydney, Austrália, 10/09/197î

\section{EDUCAÇÃO}

Colégio Santa Margarita, Lima, Peru (1978-1988)

Universidade Ricardo Palma, Faculdade de Ciências Biológicas, Lima, Peru. Bacharel em Biologia (1990-1996).

Universidade de São Paulo, Instituto de Química, Departamento de Bioquímica, Doutor em Ciências - Bioquímica (1998-2003).

\section{OCUPAÇÃo}

Bolsista: FAPESP 1998 até Maio de 2003. 


\section{PUBLICAÇÕES}

Butera D, Moura-da-Silva AM. Processo de obtenção da eristostatina/fosfatase alcalina quimérica, construção da eristostatina/fosfatase alcalina quimérica e seu produto expresso em periplasma, uso da proteina de fusão enistostatina/fosfatase alcalina e kit de diagnóstico. Patente de invenção depositada no |NP| no 31 de janeiro de 2003. Número de registro PI0300212-8.

Butera D, Skielka K, Paquette-Straub C, McLane MA, Ducancel F, Moura-da-Silva AM. Cloning, expression and characterization of a bifunctional disintegrin/alkaline phosphatase hybrid protein. Protein Expr Purif. 2003 Oct,31(2):286-91.

Moura-da-Silva AM, Della-Casa MS, David AS, Assakura MT, Butera D, Lebrun I, Shannon JD, Serrano SM, Fox JW. Evidence for heterogeneous forms of the snake venom metalloproteinase jararhagin: a factor contributing to snake venom variability. Arch Biochem Biophys. 2003 Jan 15:409(2):395-401.

Tanjoni I, Butera D, Spencer PJ, Takehara H, Fernandes I, Moura-da-Silva AM. Phylogenetic conservation of a snake venom metalloproteinase epitope recognized by a monoclonal antibody that neutralizes hemorrhagic activity. Toxicon. 2003; 42(7): $809-816$

Tanjoni I, Butera D, Bento L, Della-Casa M, Marques-Porto R, Takehara H, Gutierrez JM, Femandes I, Moura-da-Silva AM. Snake Venom Metalloproteinases: Structure/function relationships studies using monoclonal antibodies. Toxicon. 2003; 42(7): 801-808. 